Cover. View downriver of travertine dams on the Lower Little Colorado River 1 kilometer upstream from the confluence with the Colorado River, Grand Canyon National Park, Arizona. U.S. Geological Survey photograph by Joel Unema, February 2018. 


\section{Historical Floods and Geomorphic Change in the Lower Little Colorado River during the Late 19th to Early 21st Centuries}

By Joel A. Unema, David J. Topping, Keith A. Kohl, Michael J. Pillow, and Joshua J. Caster

Scientific Investigations Report 2021-5049 


\section{U.S. Geological Survey, Reston, Virginia: 2021}

For more information on the USGS — the Federal source for science about the Earth, its natural and living resources, natural hazards, and the environment-visit https://www.usgs.gov or call 1-888-ASK-USGS.

For an overview of USGS information products, including maps, imagery, and publications, visit https://store.usgs.gov.

Any use of trade, firm, or product names is for descriptive purposes only and does not imply endorsement by the U.S. Government.

Although this information product, for the most part, is in the public domain, it also may contain copyrighted materials as noted in the text. Permission to reproduce copyrighted items must be secured from the copyright owner.

Suggested citation:

Unema, J.A., Topping, D.J., Kohl, K.A., Pillow, M.J., and Caster, J.J., 2021, Historical floods and geomorphic change in the lower Little Colorado River during the late 19th to early 21st centuries: U.S. Geological Survey Scientific Investigations Report 2021-5049, 34 p., https://doi.org/10.3133/sir20215049.

Associated data for this publication:

Unema, J.A., Topping, D.J., Caster, J.J., and Kohl, K.A., 2021, Topographic data, historical peak-stage data, and 2D flow models for the lowermost Little Colorado River, Arizona, USA, 2017: U.S. Geological Survey data release, https://doi.org/10.5066/PgVGWRV1.

ISSN 2328-0328 (online) 


\section{Acknowledgments}

This study was conducted with funding through the Glen Canyon Dam Adaptive Management Program and Grand Canyon Monitoring and Research Center (GCMRC). We thank Charles Yackulic, Joel Sankey, Maria Dzul, and David Ward of GCMRC for their contributions to data collection and assistance with the manuscript. We thank Kirk Young and Dennis Stone of the U.S. Fish and Wildlife Service for their contributions. We also thank Stephanie Coffman of Stantec for assisting in data collection. All historical photographs published herein are from the Northern Arizona University Cline Library Special Collections and are reproduced with permission.

David Dean and Richard McDonald of the U.S. Geological Survey (USGS) provided detailed and helpful reviews of the manuscript. We thank Jamie Macy and Christopher Magirl of the USGS Arizona Water Science Center for support and additional reviews. 


\section{Contents}

Acknowledgments .......................................................................................................................ii

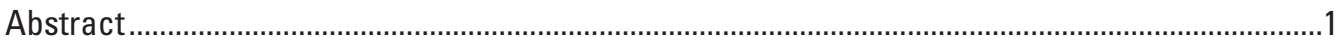

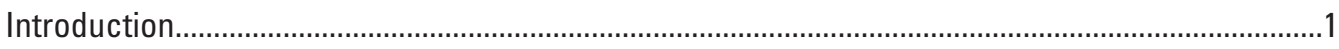

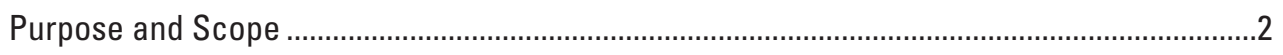

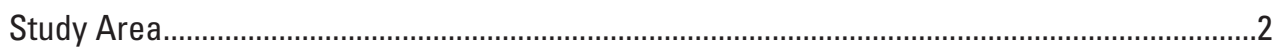

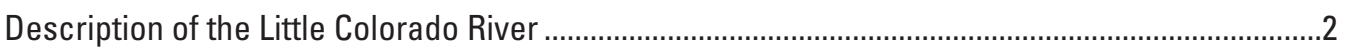

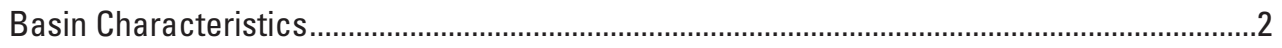

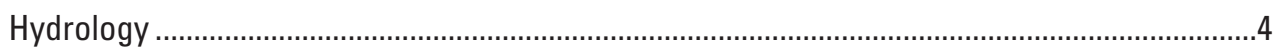

Geomorphic Processes in the Lower Little Colorado River .......................................................

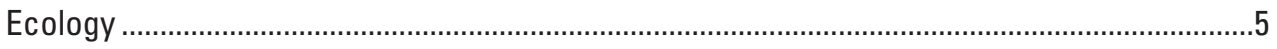

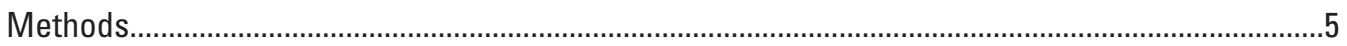

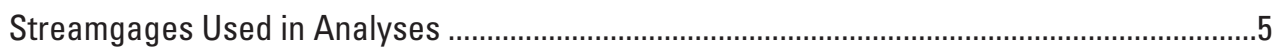

Peak-Flow History Reconstruction ...................................................................................

Topographic and High-Water-Mark Survey ……………..................................................

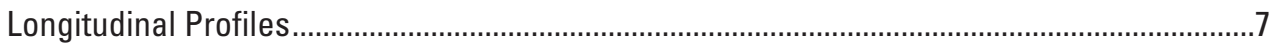

1926 Longitudinal Profile ..............................................................................................

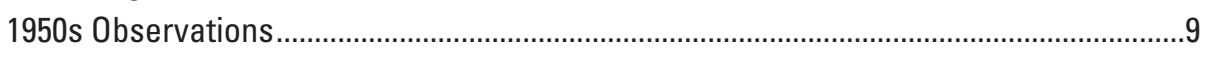

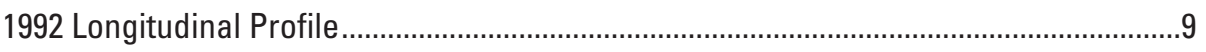

2002 and 2013 Longitudinal Profiles ........................................................................10

2017 Longitudinal Profile .............................................................................................

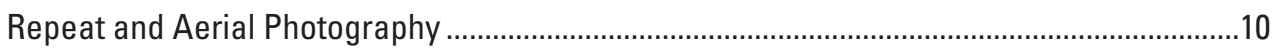

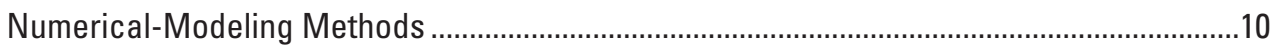

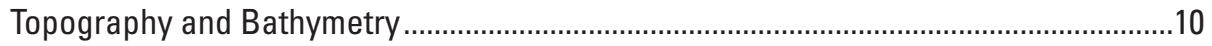

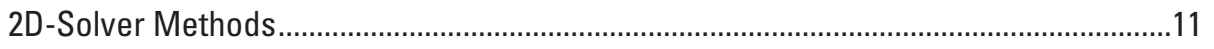

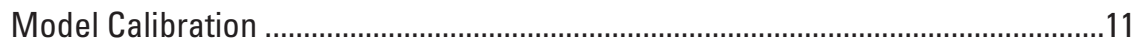

2D-Model Best-Fit Streamflow Methods ............................................................12

FaSTMECH Modeling Methods .........................................................................12

SToRM Modeling Methods.................................................................................13

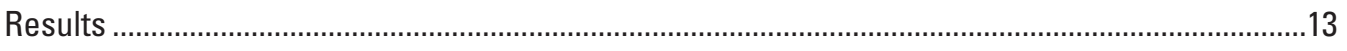

Attenuation and Traveltime of Flood Peaks .....................................................................13

Peak-Flow History of the Lower Little Colorado River ...........................................................15

Changes in the Longitudinal Profile ...................................................................................16

Classification of High-Water Marks ..........................................................................18

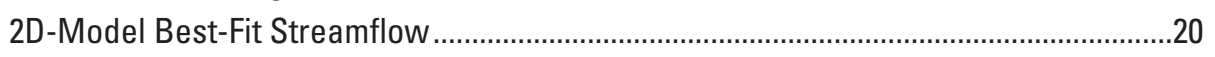

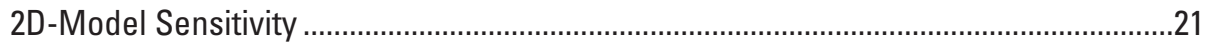

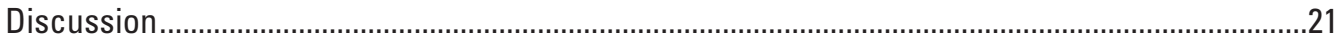

Peak-Flow History of the Lower Little Colorado River ..........................................................21

Backwater Effects from Colorado River Floods.............................................................23

Changes in the Longitudinal Profile of the Lower Little Colorado River ...................................24 


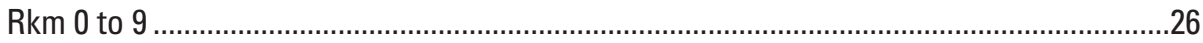

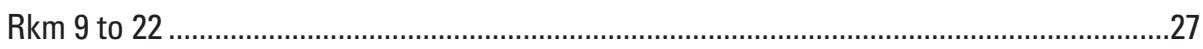

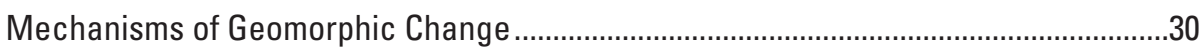

Ecological Implications of the Declines in Peak-Flow Magnitude and Associated Reduced Geomorphic Disturbance .........................................................................

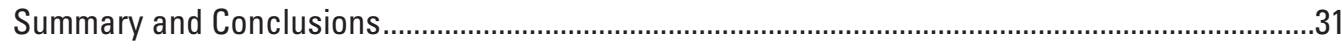

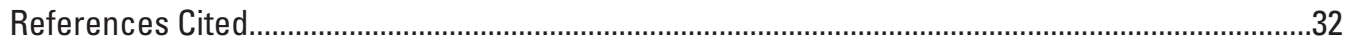

\section{Figures}

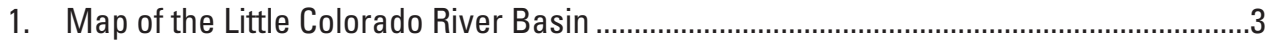

2. Study-area map of the lower Little Colorado River..........................................................

3. Aerial image of the model reach in the lower Little Colorado River .................................8

4. Plots showing model-roughness-calibration results calculated by using the

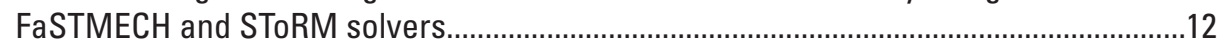

5. Plots showing the root mean square for SToRM and FaSTMECH model runs.................13

6. Plot showing the peak-flow record of the lower Little Colorado River ............................16

7. Longitudinal profiles of the lower Little Colorado River from 1926, 1992, 2002, 2013,

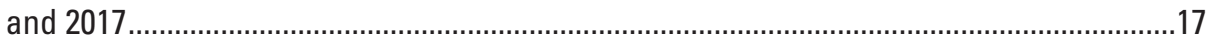

8. Plot of high-water-mark elevations on the left bank of the Little Colorado River ............18

9. Plot of high-water mark elevations on the right bank of the Little Colorado River..........19

10. Photograph of the complex geometry of ledges of Cambrian-age Tapeats Sandstone on the left bank of the Little Colorado River...................................................19

11. Histograms of high-water marks (HWMs) binned by elevation .....................................20

12. Plot showing the best-fit FaSTMECH- and SToRM-predicted streamflows for the

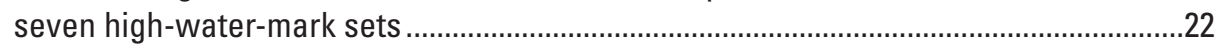

13. Plots of changes in the base-flow longitudinal profile and water-surface elevations

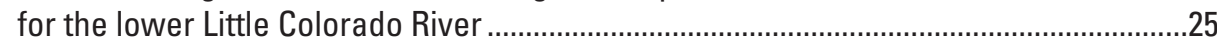

14. Repeated photographs from the 1950s and 2019 of the Little Colorado River at river

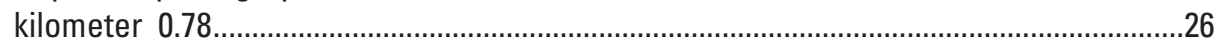

15. Repeated photographs from 1932 and 2019 of the Little Colorado River at river

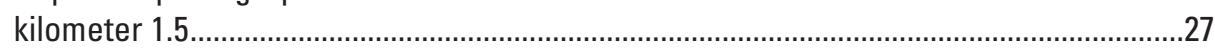

16. Repeated photographs from 1911 and 2013 of the Little Colorado River below Salt Trail Canyon at river kilometer 9.45 ....................................................................28

17. Repeated photographs from 1911 and 2013 of the Little Colorado River upstream from Big Canyon at river kilometer 11.15 ....................................................................28

18. Repeated photographs from 1911 and 2013 of the Little Colorado River upstream from Big Canyon at river kilometer 12.05 .......................................................................

19. Repeated photographs from 1909 and 2013 of Blue Spring on the left bank of the Little Colorado River at river kilometer 20.8. 


\section{Tables}

1. Streamgages on the Colorado River and Little Colorado River in Arizona used in the study.

2. Flood peak flows used for roughness verification .....................................................11

3. Traveltimes and attenuation of flood peak flows between the near-Cameron and LCR-mouth streamgages for 10 floods during the period 1993 through 2018 .................14

4. Preservable peak flows in the lower Little Colorado River ................................................ 16

5. Best-fit streamflows for each high-water-mark set .......................................................21

\section{Conversion Factors}

International System of Units to U.S. customary units

\begin{tabular}{|c|c|c|}
\hline Multiply & By & To obtain \\
\hline \multicolumn{3}{|c|}{ Length } \\
\hline meter $(\mathrm{m})$ & 3.281 & foot $(\mathrm{ft})$ \\
\hline kilometer (km) & 0.6214 & mile (mi) \\
\hline meter $(\mathrm{m})$ & 1.094 & yard (yd) \\
\hline \multicolumn{3}{|c|}{ Area } \\
\hline square meter $\left(\mathrm{m}^{2}\right)$ & 0.0002471 & acre \\
\hline square kilometer $\left(\mathrm{km}^{2}\right)$ & 247.1 & acre \\
\hline square meter $\left(\mathrm{m}^{2}\right)$ & 10.76 & square foot $\left(\mathrm{ft}^{2}\right)$ \\
\hline square kilometer $\left(\mathrm{km}^{2}\right)$ & 0.3861 & square mile $\left(\mathrm{mi}^{2}\right)$ \\
\hline \multicolumn{3}{|c|}{ Flow rate } \\
\hline cubic meter per second $\left(\mathrm{m}^{3} / \mathrm{s}\right)$ & 70.07 & acre-foot per day (acre-ft/d) \\
\hline meter per year (m/yr) & 3.281 & foot per year (ft/yr) \\
\hline cubic meter per second $\left(\mathrm{m}^{3} / \mathrm{s}\right)$ & 35.31 & cubic foot per second $\left(\mathrm{ft}^{3} / \mathrm{s}\right)$ \\
\hline cubic meter per second $\left(\mathrm{m}^{3} / \mathrm{s}\right)$ & 22.83 & million gallons per day (Mgal/d) \\
\hline
\end{tabular}

\section{Datum}

Vertical coordinate information is referenced to the North American Vertical Datum of 1988 (NAVD 88) using the Geoid 18 model.

Horizontal coordinate information is referenced to the 2011 adjustment of the North American Datum of 1983 (NAD 83 [2011]). 


\section{Abbreviations}

$\begin{array}{ll}\text { 2D } & \text { two-dimensional } \\ \text { DEM } & \text { digital elevation model } \\ \text { DSM } & \text { digital surface model } \\ \text { FIPS } & \text { Federal Information Processing Standard } \\ \text { HWM } & \text { high-water mark } \\ \text { iRIC } & \text { International River Interface Cooperative } \\ \text { lidar } & \text { light detection and ranging } \\ \text { MST } & \text { Mountain Standard Time } \\ \text { NAD 83 } & \text { North American Datum of 1983 } \\ \text { NAVD 88 } & \text { North American Vertical Datum of 1988 } \\ \text { NGS } & \text { National Geodetic Survey } \\ \text { NGVD 29 } & \text { National Geodetic Vertical Datum of } 1929 \\ \text { NWIS } & \text { National Water Information System } \\ \text { Rkm } & \text { river kilometer } \\ \text { RMSE } & \text { root mean square error } \\ \text { TIN } & \text { triangulated irregular model } \\ \text { USFWS } & \text { U.S. Fish and Wildlife Service } \\ \text { USGS } & \text { U.S. Geological Survey }\end{array}$





\title{
Historical Floods and Geomorphic Change in the Lower Little Colorado River during the Late 19th to Early 21st Centuries
}

\author{
By Joel A. Unema, ${ }^{1}$ David J. Topping, ${ }^{1}$ Keith A. Kohl, ${ }^{1}$ Michael J. Pillow, ${ }^{2}$ and Joshua J. Caster ${ }^{1}$
}

\section{Abstract}

The Little Colorado River is a major tributary to the Colorado River with a confluence at the boundary between Marble and Grand Canyons within Grand Canyon National Park, Arizona. The bedrock gorge of the lower Little Colorado River is home to the largest known population of Gila cypha (humpback chub), an endangered fish endemic to the Colorado River Basin. Channel conditions might affect the spawning success of the humpback chub. Perennial base flow in the lower Little Colorado River deposits travertine, which forms dams and cascades. Geomorphic change in the lower Little Colorado River is controlled by the growth and collapse of travertine dams, debris flows from tributaries, and reworking of dams and debris fans by Little Colorado River floods.

A study was conducted by the U.S. Geological Survey, in cooperation with the Glen Canyon Dam Adaptive Management Program and the U.S. Fish and Wildlife Service, to document historical floods and geomorphic change in the lower Little Colorado River. For this study, we used historical and gaging records and hydraulic modeling of surveyed highwater marks from historical Little Colorado River floods to construct a peak-flow history of the lower Little Colorado River. We analyzed base-flow longitudinal profiles and historical photographs to determine changes in the longitudinal profile of the lower Little Colorado River from 1909 to 2019. The peak-flow magnitudes and the frequency of larger floods have declined since the late 1800s, and the longitudinal profile of the Little Colorado River has substantially changed between 1909 and 2019. Aggradation of as much as 6 meters in some reaches occurred between 1926 and 1992, mostly before the 1950s. This aggradation was caused largely by the documented growth of travertine dams continuing through at least 2013 at several locations. Other reaches were incised by as much as 10 meters between 1926 and 1992, but mostly before the 1950s, largely from the breaching of travertine dams. Travertine dams in the Little Colorado River have survived large flooding events and then later collapsed during floods of lower streamflow or even periods of base flow. The decline in peak-flow magnitude and frequency has changed

${ }^{1}$ U.S. Geological Survey.

${ }^{2}$ U.S. Fish and Wildlife Service. the dominant geomorphic processes in this formerly dynamic reach. Large incision events have not been documented since the early 1950s; for this reason, the reach has only aggraded or remained stable since that time. This loss of geomorphic disturbance has likely affected, and will likely continue to affect, the spawning habitat of the endangered humpback chub in the lower Little Colorado River.

\section{Introduction}

The Little Colorado River is a major tributary to the Colorado River with a confluence at the boundary between Marble and Grand Canyons within Grand Canyon National Park, Arizona. The lower 22-kilometer $(\mathrm{km})$ reach of the Little Colorado River is a bedrock gorge with perennial flow of travertine-depositing waters. The channel morphology is controlled, in part, by debris flows, travertine-dam growth, reworking of debris fans by main-stem floods, and travertinedam collapse (Howard and Dolan, 1981). The lower Little Colorado River hosts the largest known population of the endangered Gila cypha (humpback chub) (Douglas and Marsh, 1996; Coggins and others, 2006). Although some of their spawning locations are uncertain, ripe spawning humpback chub show preferences for deep water, complex flow structure, proximal boulders and travertine dams, and a clean gravel bed (Gorman and Stone, 1999); as a result, changing channel conditions in the lower Little Colorado River could affect chub spawning.

Previous studies have found substantial geomorphic changes since the early 1900s in the predominantly alluvial reaches upstream from the lower bedrock gorge (Hereford, 1984; Block, 2014; Dean and Topping, 2019). Changes in these alluvial reaches include channel narrowing, floodplain growth, increases in sinuosity, and channel-bed aggradation and are thought to be driven by a decline in peak-flow magnitude owing largely to increases in channel-margin and floodplain vegetation and increased water development, including groundwater development and small impoundments or dams on tributaries. A previous study assessed the changes in the longitudinal profile of the lower Little Colorado River from 1926 to 2002 and found that the lower $10 \mathrm{~km}$ of the reach had generally been aggraded while the upper $12 \mathrm{~km}$ reach had been incised (Persio, 2004). Persio attributed the 
observed aggradation to debris-flow deposition and travertinedam growth but did not provide an explanation for the incision.

A recent study was conducted by the U.S. Geological Survey, in cooperation with the Glen Canyon Dam Adaptive Management Program and the U.S. Fish and Wildlife Service, to document historical floods and geomorphic change in the lower Little Colorado River. This study was conducted to investigate the possible effects of changes in peak-flow magnitude and frequency on the morphology of the lower Little Colorado River and possible implications for fish habitat. For this study, we used historical and gaging records and hydraulic modeling of surveyed high-water marks from historical Little Colorado River floods to construct a peakflow history of the lower Little Colorado River. We analyzed base-flow longitudinal profiles and historical photographs to determine changes in the longitudinal profile of the lower Little Colorado River from 1909 to 2019.

\section{Purpose and Scope}

This report provides analyses of gaging and historical records and describes modeling results to evaluate the possible effects of changes in streamflow on changes in the longitudinal profile of the lower $22 \mathrm{~km}$ of the Little Colorado River. The report also describes several geomorphic processes that affect the longitudinal profile of the lower Little Colorado River, including aggradation caused by debris flows and the slow growth of travertine dams. Incision in this reach occurs by the partial or complete collapse of travertine dams and the reworking of debris-flow deposits by Little Colorado River floods. We utilize historical high-water marks (HWMs), longitudinal profiles constructed from survey and remotesensing data, streamflow records from U.S. Geological Survey (USGS) streamgages on the Little Colorado and Colorado Rivers, photographic sequences, aerial photography, and hydraulic modeling to interpret geomorphic changes in the lower Little Colorado River. We also investigate possible changes in peak-flow hydrology that might affect channel morphology in this reach. All data compiled for this study and the model archive are available from Unema and others (2021).

\section{Study Area}

The study area is the lowest $22 \mathrm{~km}$ of the Little Colorado River extending from just upstream from Blue Spring to its confluence with the Colorado River (figs. 1 and 2). The spring waters that make up the perennial flow in this reach form travertine. The channel is a bedrock gorge with many small steep tributaries and two larger named tributaries in Salt Trail Canyon and Big Canyon (fig. 2). Step-pool morphology (Montgomery and Buffington, 1997) characterizes the reach, with steps formed by debris fans and travertine dams. The Blue Spring complex and other springs provide a steady base flow of 6.3 cubic meters per second $\left(\mathrm{m}^{3} / \mathrm{s}\right)$ of water that is supersaturated with calcium carbonate (Johnson and Sanderson, 1968; Cole, 1975). Blue Spring is the largest single supplier of this water and has a steady discharge of $\sim 2.7 \mathrm{~m}^{3} / \mathrm{s}$
(Bills and others, 2007). This base flow has remained steady since at least the early 1950s (U.S. Geological Survey, 1952; U.S. Geological Survey, 2019) and possibly for many hundreds of years given the 22,600- to 1,100-year-old age (Bills and others, 2007) and the partial-mantle origin of the water discharged from these springs (Crossey and others, 2009).

The lower Little Colorado River and its confluence with the Colorado River provide important habitat for the endangered humpback chub. Locations within the study area are described by position in river kilometers ( $\mathrm{Rkm}$ ) along the Zero Rock Centerline (named for a large boulder established as the zero point near the confluence) and used by the U.S. Fish and Wildlife Service (USFWS) and the USGS Grand Canyon Monitoring and Research Center. The centerline begins with Rkm 0 just upstream from its confluence with the Colorado River and follows the center of the channel of the Little Colorado River to the upstream end of the study reach, Rkm 20.8, at Blue Spring (figs. 2 and 3).

\section{Description of the Little Colorado River}

This section of the report describes the Little Colorado River in terms of basin characteristics and hydrology. Geomorphic processes in the lower Little Colorado River and ecology are also described.

\section{Basin Characteristics}

The Little Colorado River originates in the White Mountains of Arizona and flows $565 \mathrm{~km}$ through northeastern Arizona (fig. 1) (Block, 2014). Its drainage basin of 70,000 square kilometers $\left(\mathrm{km}^{2}\right)$ includes the northeastern slope of the Mogollon Rim escarpment and most of the Black Mesa highland area on the Navajo Nation (Hereford, 1984).

The Little Colorado River is perennial from its headwaters for $60 \mathrm{~km}$ to Lyman Lake, the basin's largest reservoir (fig. 1). The river is heavily regulated by Lyman Lake, and flows seasonally $40 \mathrm{~km}$ to Zion Reservoir. The Little Colorado River is then ephemeral from Zion Reservoir to the mouth of Chevelon Creek, near Winslow, Ariz. Spring discharge from Chevelon Creek and Clear Creek adds a small amount of base flow and creates a perennial reach for only a few kilometers. Farther downstream, the river again becomes ephemeral, with alternating sections of sand- and gravel-bedded channel and bedrock-floored channel that extend approximately $90 \mathrm{~km}$ to Grand Falls. This ephemeral sand- and gravel-bedded and bedrock-floored channel extends another $60 \mathrm{~km}$ to Cameron, Ariz. Moenkopi Wash, an important tributary to the Little Colorado River, enters about $4 \mathrm{~km}$ downstream from Cameron. Approximately $13 \mathrm{~km}$ downstream from Cameron, the Little Colorado River enters a bedrock gorge that extends approximately $78 \mathrm{~km}$ to its confluence with the Colorado River. The Little Colorado River remains ephemeral in the gorge until reaching the Blue Spring complex (fig. 2), which creates perennial base flow approximately $21 \mathrm{~km}$ upstream from the Colorado River. 


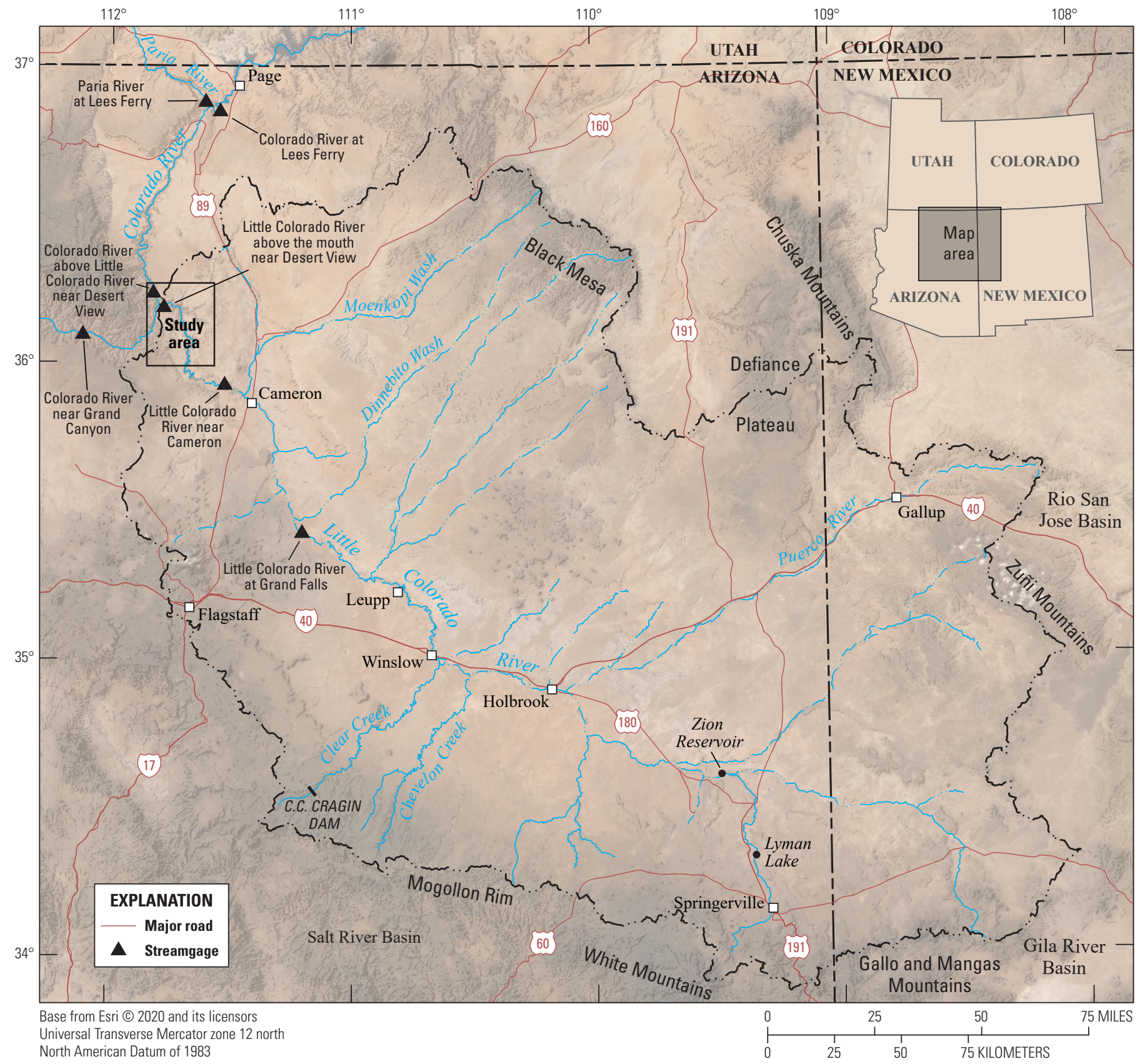

Figure 1. Map of the Little Colorado River Basin in Arizona showing the locations of U.S. Geological Survey (USGS) streamgages, tributaries, and other features. Streamgages (and USGS identification numbers) used in this study are Little Colorado River at Grand Falls (09401000), Little Colorado River near Cameron (09402000), Little Colorado River above the mouth near Desert View (09402300), Colorado River at Lees Ferry (09380000), Paria River at Lees Ferry (09382000), Colorado River above Little Colorado River near Desert View (09383100), and Colorado River near Grand Canyon (09402500). 


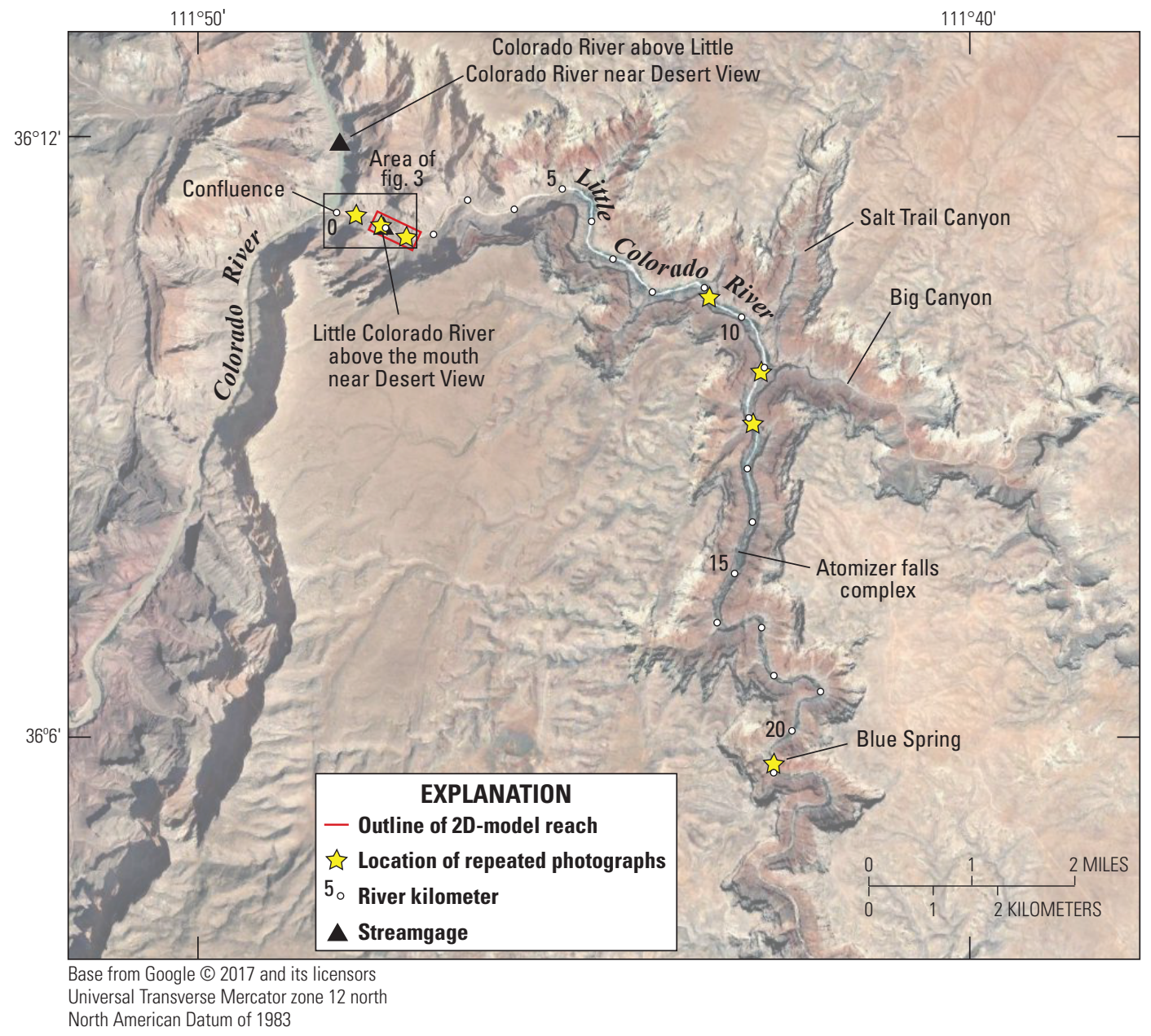

Figure 2. Study-area map of the lower Little Colorado River showing locations of streamgages, topographic features, model reach, and repeated photographs (yellow stars). 2D, two dimensional.

\section{Hydrology}

The gaging record for the lower Little Colorado River is incomplete, with a partial record extending back to 1990. Streamgages upstream on the Little Colorado River at Grand Falls and near Cameron (fig. 1) have provided a combined continuous record from November 1925 to the present (U.S. Geological Survey, 2019). Flow in the river segments without perennial base flow occurs during winter and spring and is driven by frontal precipitation (Hansen and others, 1981; Dean and Topping, 2019). The Little Colorado River also flows after summer and fall thunderstorm-generated intense rainfalls (Adams and Comrie, 1997; Dean and Topping, 2019). The mean annual peak flow was approximately $280 \mathrm{~m}^{3} / \mathrm{s}$ for the reaches near Grand Falls and Cameron from 1926 to 2015. About two-thirds of all annual peak flows occurred between June and September during this time. Dean and Topping (2019) found that, although total annual flow alternated between periods of high (1926-1943, 1965-1995) and low (1944-1964, 1996-2015) flow, peak-flow magnitudes progressively declined in the Little Colorado River between 1926 and 2015. Conversely, no decline in peak-flow magnitude occurred over the same time interval in the Salt and Gila Rivers, which are adjacent to, and have precipitation patterns similar to, those in the Little Colorado River Basin (fig. 1; Dean and Topping, 2019). They interpreted this result as indicating that the peakflow decline in the Little Colorado River was largely caused by non-climatic changes within its basin.

\section{Geomorphic Processes in the Lower Little Colorado River}

Travertine deposition is an important geomorphic process in the lower Little Colorado River. As spring waters supersaturated with calcium carbonate move downstream, free carbon dioxide is lost to the atmosphere, and calcium carbonate precipitates as particles that locally cement gravel and form travertine dams (Cole, 1975; Robinson and others, 1996). Dam growth rates have been measured in other travertine-dominated streams in Arizona (Fuller and others, 
2011). For example, the median growth rate measured in Fossil Creek was 0.025 meter per year (m/yr). Travertine dams form riffles, steps, or falls in the Little Colorado River and can become tall enough to form barriers to the upstream movement of fish (Robinson and Clarkson, 1992; Robinson and others, 1996).

Channel aggradation in the lower Little Colorado River also occurs by deposition from debris flows. Persio (2004) assessed the change in the base-flow longitudinal profile of the lower Little Colorado River between 1926 and 2002, with an emphasis on the effects of debris flows. Persio (2004) developed a stochastic model of debris-flow probability for the tributaries of the lower Little Colorado River and produced a map depicting these probabilities. Deposition of travertine occurs preferentially in areas of greater turbulence (Giegengack and others, 1979), leading to increased dam growth and aggradation near the larger boulders in the debrisflow deposits.

Large main-stem floods are the primary mechanism by which debris-flow-affected rivers rework debris-flow deposits (Webb, 1987). Travertine dams may fail during large floods or may simply become unstable and collapse after long periods of growth. For example, the informally named Chute falls of what is locally known as the Atomizer falls complex (fig. 2) partially collapsed between October 2016 and June 2017 (Dennis Stone, USFWS, written commun., 2017), a period including 3 months of slightly elevated flow reaching a maximum of only $56 \mathrm{~m}^{3} / \mathrm{s}$.

\section{Ecology}

The largest population of humpback chub in the Grand Canyon region is in the lower $14 \mathrm{~km}$ of the Little Colorado River (Gorman and Stone, 1999). Aggregation of spawning male and female chub occurs in waters 0.5 to 2 meters (m) deep with travertine dams, numerous boulders, and clean (uncemented) gravel on the bed (Gorman and Stone, 1999). Spawning of humpback chub occurs during the spring months and extends from about Rkm 3 upstream to Rkm 13 (fig. 2). Chute falls, part of the so-called Atomizer falls complex (fig. 2), forms an impediment to chub movement upstream from $\mathrm{Rkm}$ 14. Both the changes in carbon dioxide $\left(\mathrm{CO}_{2}\right)$ concentrations near Chute falls and the physical height of the falls inhibit the upstream movement of chub (Stone and others, 2018).

\section{Methods}

We used streamflow data from USGS streamgages to reconstruct the peak-flow history for the lower Little Colorado River. We then surveyed topography, bathymetry, and HWMs in 2017 to use in two-dimensional (2D) flow models. These models were used to construct a peak-flow sequence in the study area to compare with the peak-flow history from the gaging records. Previously published longitudinal profiles of the Little Colorado River were compared with longitudinal profiles digitized from topographic datasets to evaluate changes in the base-flow water-surface profile over time. We also used multiple repeated ground-based oblique and aerial photographs to confirm longitudinal-profile changes and determine the timing and mechanisms of this change.

\section{Streamgages Used in Analyses}

Streamflow records from USGS streamgages on the Little Colorado River and Colorado River were used in the study for evaluations of the peak-flow history and flow modeling. These records were obtained from the USGS National Water Information System (NWIS) and the online database of the USGS Grand Canyon Monitoring and Research Center. Instantaneous streamflow data from these streamgages can be viewed at the NWIS website (https://waterdata.usgs.gov; U.S. Geological Survey, 2019) and at https://www.gcmrc. gov/discharge_qw_sediment/stations/GCDAMP. The study reach contains one streamgage - the Little Colorado River above the mouth near Desert View (hereafter referred to as the LCR-mouth streamgage) (table 1) - located $1.2 \mathrm{~km}$ upstream from the confluence of the Little Colorado and Colorado Rivers. The LCR-mouth streamgage was operated from 1990 to 1993 and, after reestablishment in 2003, has been operated continuously since then. Data from two other streamgages outside the study reach - the Little Colorado River at Grand Falls and near Cameron (hereafter referred to as the Grand Falls streamgage and near-Cameron streamgage, respectively) (table 1, fig. 1) —were also used. The Grand Falls streamgage was operated from 1925 to 1960 (with some data gaps between 1949 and 1954) and from 1990 to 1995; since reestablishment in 2001, it has been operating continuously. The near-Cameron streamgage has been operated from 1947 to the present. The reach between the near-Cameron streamgage and the LCR-mouth streamgage is within a narrow approximately 70-km-long bedrock canyon with negligible input of water between the near-Cameron streamgage and the Blue Spring complex; attenuation of peak flows between these streamgages is generally negliglible. For this reason, the streamflow record from the near-Cameron streamgage can be used in place of the record from the LCR-mouth streamgage for large floods.

We used the records from the Grand Falls streamgage, which is $82 \mathrm{~km}$ upstream from the near-Cameron streamgage, to determine the peak flows of floods that occurred before the 1947 establishment of the near-Cameron streamgage (table 1). The river bed between the Grand Falls and near-Cameron streamgages include wide alluvial reaches. Dinnebito Wash and Moenkopi Wash, major tributaries that drain the highlands of Black Mesa, join the Little Colorado River between these streamgages (fig. 1). Because of infiltration in the sandy channel, tributary inputs of water, and peak-flow attenuation, the peak flows of floods might change between the Grand Falls and near-Cameron streamgages. Before large channel changes increased the downstream attenuation of floods between these streamgages during the latter half of the 20th century (Dean and Topping, 2019), the peak flows of floods were generally 
Table 1. Streamgages on the Colorado River and Little Colorado River in Arizona used in the study (fig. 1).

[Data can be accessed from U.S. Geological Survey (2019) using the station numbers. km, kilometer; km², square kilometer; LCR, Little Colorado River]

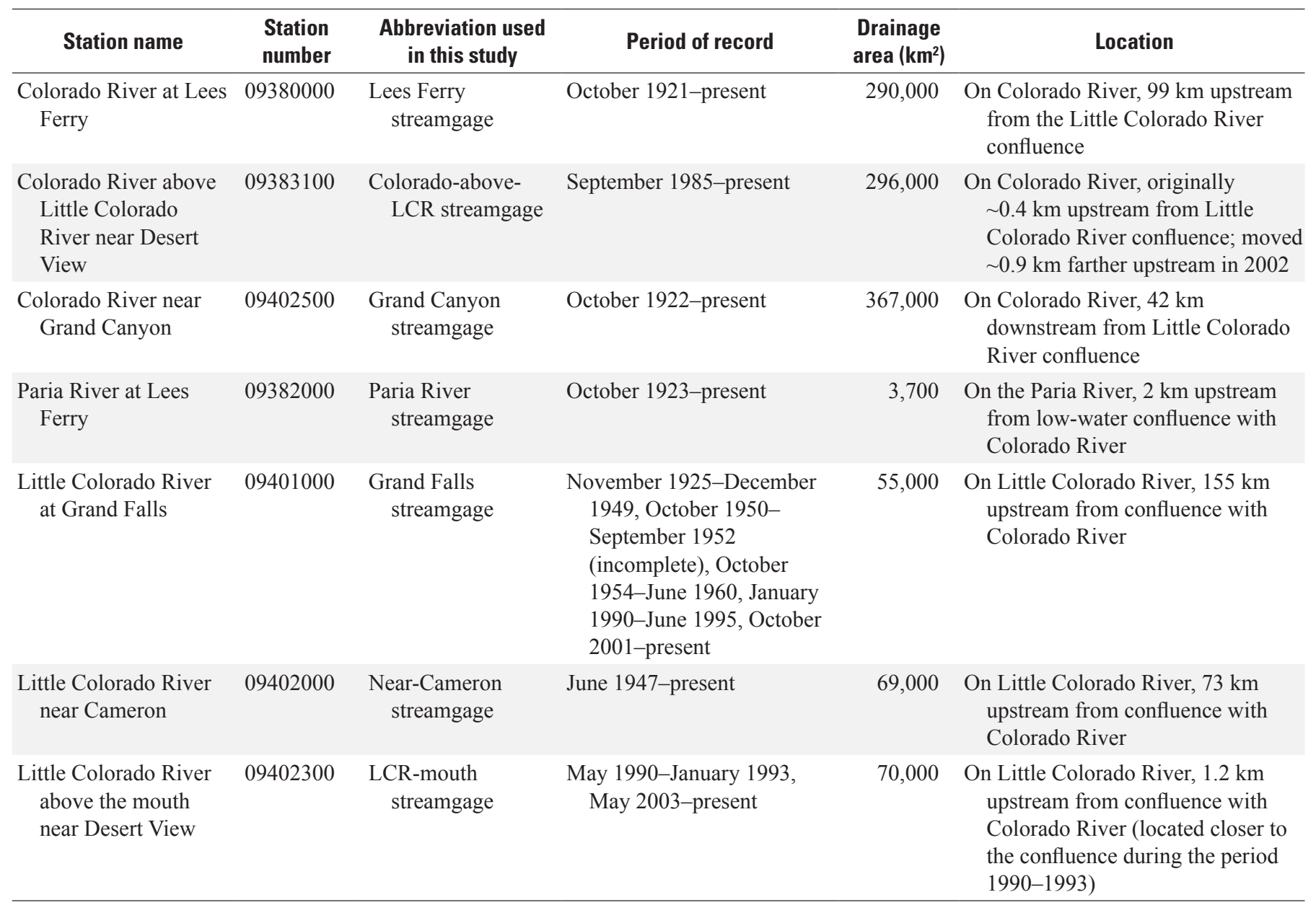

similar at the Grand Falls and near-Cameron streamgages. Thus, although we could not fully constrain the tributary inflow between these streamgages, we used the record from the Grand Falls streamgage to reconstruct the peak-flow history of the lower Little Colorado River before the 1947 establishment of the near-Cameron streamgage.

Three streamgages on the Colorado River were also used, including the Lees Ferry streamgage, which is $99 \mathrm{~km}$ upstream from the confluence with the Little Colorado River and has a complete streamflow record that begins in 1921 (Topping and others, 2003). We also used the streamflow records from the Colorado River above Little Colorado River near Desert View (hereafter referred to as the Colorado-above-LCR streamgage), just upstream from the confluence, and the Colorado River near Grand Canyon (hereafter referred to as the Grand Canyon streamgage), $42 \mathrm{~km}$ downstream from the confluence.

\section{Peak-Flow History Reconstruction}

Records from the LCR-mouth, near-Cameron, and Grand Falls streamgages were used to reconstruct a peak-flow history of the lower Little Colorado River. We used records from the Lees Ferry and Grand Canyon streamgages to identify peak flows in the Little Colorado River before November 1925 the period before establishment of the Grand Falls streamgage. The typical traveltime of large flood peaks between the near-Cameron and LCR-mouth streamgages was estimated by averaging the differences in the times of peak flow between the streamgages during 10 major events that occurred from 1993 through 2018. Dean and Topping (2019) demonstrated that, in the wide alluvial reaches of the Little Colorado River upstream from the near-Cameron streamgage, the traveltimes of flood peaks have increased substantially since the mid-20th 
century in response to greatly increased channel narrowing, sinuosity, and vegetative roughness. Dean and Topping (2019) also showed that the Little Colorado River in the narrow bedrock canyon at the near-Cameron streamgage has, in comparison, undergone substantially less narrowing and only negligible increases in sinuosity. Thus, our estimation of the traveltimes of historical floods between the near-Cameron and LCR-mouth streamgages by the use of the modern records from these streamgages is appropriate because the traveltimes of flood peaks through this bedrock canyon have not likely changed substantially over time in response to changes in channel geometry and roughness.

\section{Topographic and High-Water-Mark Survey}

In June 2017, we measured the channel bathymetry and above-water topography along the Little Colorado River from Rkm 0.4 upstream to Rkm 1.8 by combining data collected by a traditional total-station survey and ground-based light detection and ranging (lidar) (Unema and others, 2021). This short reach includes the LCR-mouth streamgage. These surveys were conducted at base flow $\left(6.2 \mathrm{~m}^{3} / \mathrm{s}\right)$. We collected bathymetry measurements by using a total station referenced to the USGS control network inside the Grand Canyon National Park. All total-station measurements were collected according to survey protocols with an assumed elevation uncertainty of $0.03 \mathrm{~m}$ (Collins and others, 2008).

For the above-water topography, we used a RIEGL VZ-1000 ground-based lidar unit to collect ground-surface measurements to elevations as high as $100 \mathrm{~m}$ above the active channel. The above-water survey used 38 scan positions referenced by 22 control targets surveyed by using the same total-station position and control network as the bathymetry. Data registration among all 38 scans was equal to or less than $0.01 \mathrm{~m}$. To generate topography from the point cloud, the data were first processed to remove vegetation by an iterative height filter in the Maptek I-Site Studio (ver. 6x) that creates a bare-ground point cloud. The mean density of the processed point cloud was equal to or greater than 400 points per meter.

The total-station bathymetry and lidar point clouds were joined to create a single digital elevation model (DEM) in a two-stage process. The first stage generated a hydrologically correct base-flow water surface. Because some of the lidar point cloud included travertine dams in the active channel, the bare-ground point cloud surrounding the base-flow water surface was combined with the total-station bathymetry to generate breaklines and topographic contours within the stream channel. These breaklines and contours were then combined with the original survey points to create an in-channel surface geometry by using Esri ArcGIS (ver. 10x) to interpolate topographic and correct hydrologic data. Interpolation error represented by the root mean square error (RMSE) of differences between the in-channel geometry and the total-station bathymetric measurements was $0.03 \mathrm{~m}$. In the second stage, the interpolated channel geometry was joined to the above-water lidar point cloud to create a single triangulated irregular model (TIN). The TIN surface was then converted to a $0.05-\mathrm{m}$ resolution DEM to be used for numerical flow modeling. All horizontal positions in this study are in North American Datum of 1983 (NAD 83) State Plane Arizona Central Federal Information Processing Standard (FIPS) 2002 coordinates, and all vertical positions (hereafter called elevations) are in North American Vertical Datum of 1988 (NAVD 88) orthometric heights that were converted from NAD 83 ellipsoid height by using the Geoid 18 model.

In addition to bathymetry, we also surveyed the positions of HWMs along this reach by using the total station during June 2017 to simulate historical floods. HWMs consisted of woody-debris deposits (Koenig and others, 2016). We measured a total of $147 \mathrm{HWMs}$, whose elevations ranged from 825.6 to $847.6 \mathrm{~m}$ (Unema and others, 2021). We classified HWMs into distinct sets that we interpreted by a two-step detrending and binning process as strandlines deposited during individual floods.

\section{Longitudinal Profiles}

A longitudinal profile was obtained from our survey and compared with longitudinal profiles constructed by using topographic data from 1926, 1992, 2002, and 2013 to evaluate changes in base-flow water-surface elevation in the study reach. Longitudinal distances in these profiles were measured along the Zero Rock Centerline used by the USGS and USFWS. The zero point-at the "Zero Rock" on the Zero Rock Centerline - is located on the right bank of the Little Colorado River just downstream from the head of the large gravel bar at the confluence of the Colorado and Little Colorado Rivers (fig. 3). Elevations estimated from repeated photographs, aerial photographs, and observations of Colorado River backwater were also included as additional discrete data points in these analyses.

\section{Longitudinal Profile}

The oldest longitudinal profile of the entire lower Little Colorado River was completed in 1926 by USGS surveyor J.L. Lewis, who used traditional topographic-surveying techniques, including differential leveling (U.S. Geological Survey, 1927). The survey extended $165 \mathrm{~km}$ from the confluence of the Little Colorado and Colorado Rivers to a proposed dam site $10 \mathrm{~km}$ upstream from Grand Falls. The zero point for Lewis' longitudinal survey was located in the middle of the Colorado River on the upstream side of the large gravel bar at the confluence of the Colorado and Little Colorado Rivers, approximately $0.3-\mathrm{km}$ downstream from the Zero Rock. The section of the profile in the study reach was digitized and published by Persio (2004). Digitized locations along Lewis' profile were projected on to the Zero Rock Centerline. Digitized elevation data were re-referenced by using two benchmarks included in the 1926 survey by Lewis. The two benchmarks closest to the study area are USGS brass caps - the first at Cape Solitude, and the second at the 


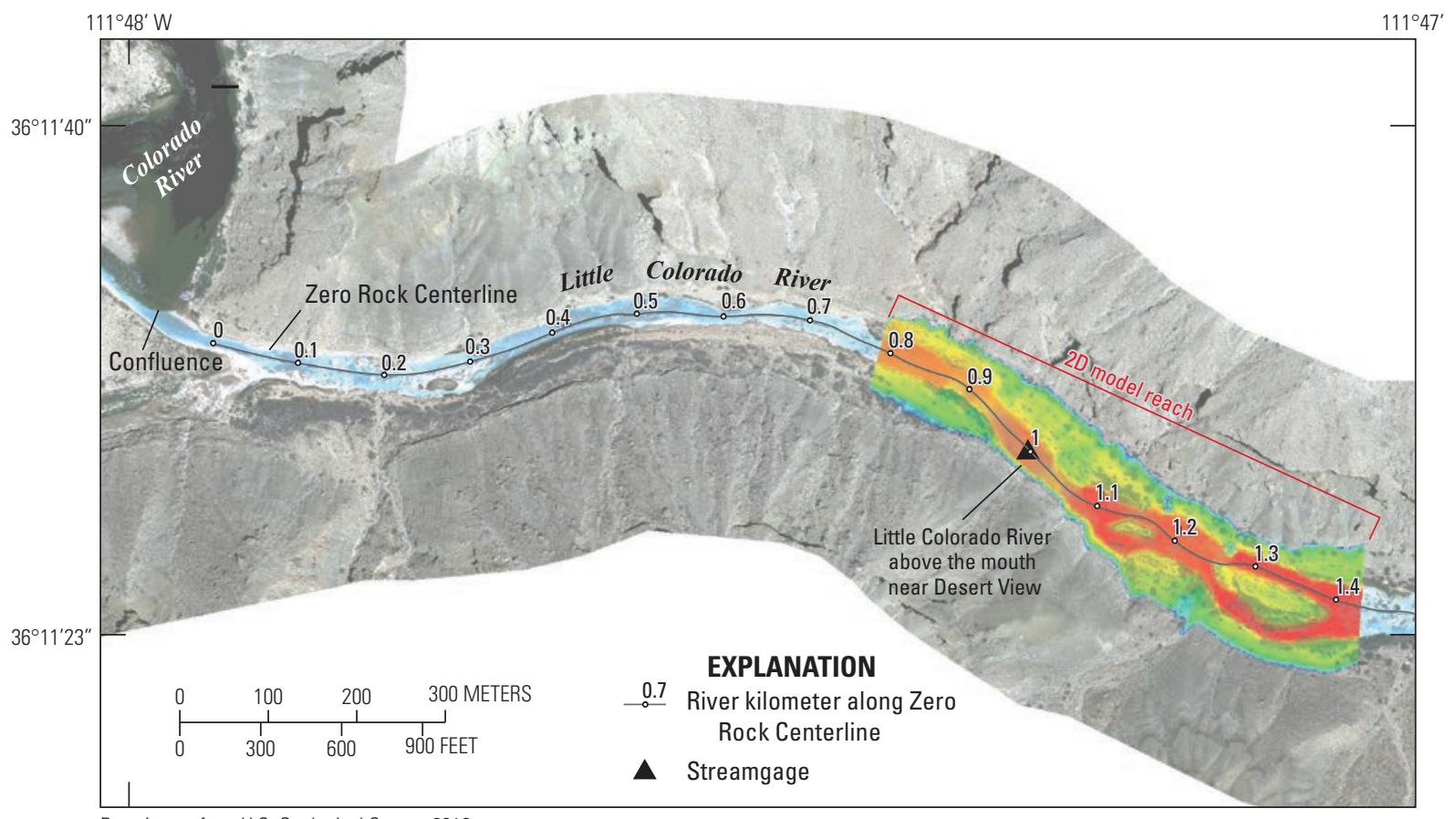

Base image from U.S. Geological Survey, 2013

Universal Transverse Mercator zone 12 north

North American Datum of 1983

Figure 3. Aerial image taken in 2013 of the model reach in the lower Little Colorado River. The Zero Rock Centerline is shown with distances in tenths of a kilometer upstream from the "Zero Rock." The Little Colorado River above the mouth near Desert View, Arizona, streamgage is labeled near the middle of the model reach, and an example output from a two-dimensional (2D) flow-model run indicates the extent of the model reach; the streamflow simulated in this run was 3,400 cubic meters per second. Warm and cool colors show greater and shallower water depths, respectively.

old Highway 89 suspension bridge in Cameron, Ariz., $18 \mathrm{~km}$ upstream from the near-Cameron streamgage. The official National Geodetic Survey (NGS) and USGS Permanent Identifier names of these benchmarks are GP0537 and FQ0163, respectively. Published orthometric and ellipsoid heights were obtained for these benchmarks from the NGS. Comparison of elevations published by Lewis (U.S. Geological Survey, 1927) with the NAVD 88 orthometric heights reported by the NGS indicated that either $0.670 \mathrm{~m}$ had to be added to Lewis' measured elevation of the Cameron benchmark, or $2.743 \mathrm{~m}$ had to be subtracted from Lewis' measured elevation of the Cape Solitude benchmark, to make his 1926 elevations agree with the NAVD 88 orthometric heights.

Evaluation of the errors associated with the methods used by Lewis in 1926 indicates that the Cameron offset of $+0.670 \mathrm{~m}$ is the correct offset required to convert Lewis' 1926 survey measurements to compatibility with the NAVD 88. Lewis likely used a differential-level survey (Birdseye, 1928) to measure the elevation of the Cameron benchmark given the small 32-m vertical separation between the Little Colorado River and this benchmark. Lewis likely used triangulation to measure the elevation of the Cape Solitude benchmark because of the impassable cliffs and the large 1,030-m vertical separation between the Little Colorado River and this benchmark. Because there is significantly less error in elevations measured by differential leveling than those measured by triangulation, the offset indicated by the Cameron benchmark (+0.670 m) was used to convert Lewis' 1926 survey elevations to NAVD 88 orthometric heights.

The $+0.670 \mathrm{~m}$ offset of the Cameron benchmark is corroborated by survey data from Birdseye's 1923 survey (U.S. Geological Survey, 1924) and by a photograph taken by E.C. LaRue during that 1923 survey. Additional support that this offset is correct is provided by additional repeatphotography data presented in the "Discussion" section. Both Lewis' survey data (1926) and LaRue's photograph (1923) indicate that the water-surface elevation of the confluence was within 1 to $2 \mathrm{~m}$ of its present-day elevation during Colorado River flows of $226-283 \mathrm{~m}^{3} / \mathrm{s}$. Although it is possible that the confluence elevation changed between 1923 and 1926, no data have been found to support this possibility. Data from Magirl and others (2005) indicate that the net change in water-surface elevation at the confluence from 1923 to 2000 was $+0.11 \pm 1.4 \mathrm{~m}$ at the 95 -percent confidence level, 
although much larger short-term changes in the elevation of the confluence have been observed after large Little Colorado River floods (Schmidt and others, 2004). Given the likely magnitude of the errors associated with Lewis' surveying methods and the uncertainty associated with the applied benchmark offset used in this study, an uncertainty of $\pm 1.5 \mathrm{~m}$ was assigned to the elevations in the 1926 longitudinal profile.

\section{0s Observations}

No complete longitudinal profiles of the lower Little Colorado River were surveyed in the mid-1900s, so USGS backwater-extent observations, repeated photographs (described in a subsequent section), and aerial photographs were used to estimate the 1950s water-surface elevation of the Little Colorado River at discrete locations. USGS hydrographers W.L. Heckler and R.B. Sanderson measuring spring inflow to the Little Colorado River recorded the headward extent of the backwater caused by large Colorado River floods in 1952 and 1953 (U.S. Geological Survey, 1952). They recorded the date and maximum distance the backwater extended upstream in the Little Colorado River. It is likely that they used the 1926 maps produced by Lewis (U.S. Geological Survey, 1927) because no other detailed maps of the lower Little Colorado River existed in the early 1950s, and also because the approximate upstream distances in their notes matched Lewis' locations of known geographic features-for example, Salt Trail Canyon and Big Canyon. Because Heckler's and Sanderson's distances were sometimes highly approximate, we assigned an uncertainty of $\pm 0.5 \mathrm{~km}$ to their backwater observations. On June 7, 1952, Heckler and Sanderson reported that the backwater extended to mile 2.3, a location equivalent to approximately $\mathrm{Rkm} 3.1 \pm 0.5$ along the Zero Rock Centerline; however, this location is impossible. Mid-channel rocks observed in aerial photographs from 1951, 1954, 1958, and 2013 indicate negligible change in the base-flow water-surface elevation between 1951 and 2013 at both Rkms 2.5 and 3.2. If their Rkm 3.1 location of the headward extent of backwater was correct, it would place the base-flow water-surface elevation about $12 \mathrm{~m}$ lower at this location than was observed after 1951. Thus, it is likely that they made a transcription error when typing their field notes, and that the true location of the headward extent of the Colorado River backwater on June 7, 1952, was at mile 1.3 , a location approximately the same as Rkm $1.5 \pm 0.5$. The Colorado River streamflow on that date at the Lees Ferry streamgage (the streamflow traveltime from Lees Ferry to Little Colorado River was about 8.5 hours) was approximately $2,900 \mathrm{~m}^{3} / \mathrm{s}$. On May 15, 1953, USGS hydrographers Heckler and Sanderson observed the farthest extent of backwater at about Rkm 1.1 \pm 0.5 (fig. 3). Colorado River streamflow at Lees Ferry was $362 \mathrm{~m}^{3} / \mathrm{s}$ on May 15 . We assigned crude elevations to these 1952 and 1953 observations based on the elevations of driftwood strandlines surveyed along the Colorado River and the earliest (1985) stage-discharge relation at the future Colorado-above-LCR streamgage (fig. 1).
The Colorado River strandlines that we used to define a stage-discharge relation at the confluence to infer the $1950 \mathrm{~s}$ backwater elevations were likely deposited at the peaks of $4,810 \mathrm{~m}^{3} / \mathrm{s}$ for the 1921 flood, $3,540 \mathrm{~m}^{3} / \mathrm{s}$ for the 1957 flood, and 3,000 $\mathrm{m}^{3} / \mathrm{s}$ for the 1958 flood (Sabol and others, 2021). The stage-discharge relation defined by these pre-1958 Colorado River strandlines is shifted $0.7 \mathrm{~m}$ higher relative to the 1985 stage-discharge relation developed for both the Colorado-above-LCR streamgage and the surveyed 1983 and 1996 Colorado River strandlines, thus indicating that the confluence elevation was about $0.7 \mathrm{~m}$ higher in the $1950 \mathrm{~s}$ than in the 1980s. According to this strandline stage-discharge relation, the elevation of the base flow water surface in the Little Colorado River at the headward extent of the Colorado River backwater was $837.3 \pm 1 \mathrm{~m}$ on June 7,1952 , and $829.4 \pm 1 \mathrm{~m}$ on May 15, 1953.

The \pm 1 -m uncertainty in these backwater elevations arises from two physical processes. First, these elevations are based on the assumption of a flat water surface over the backwatered lowermost reach of the Little Colorado River. In reality, however, the water surface in the backwatered reach may have a non-zero slope, thus resulting in approximately $0.1 \mathrm{~m}$ or more of elevation uncertainty. Second, an additional complication in the elevations estimated from backwater observations arises from the fact that large Little Colorado River floods have been observed to cause multi-year increases of about $0.3 \mathrm{~m}$ in the bed elevation of the Colorado River near the confluence and temporary increases of about $0.64 \mathrm{~m}$ in the water-surface elevation of the Colorado River near the confluence (Schmidt and others, 2004). Large floods on the Little Colorado River preceded both 1950s backwater observations and could therefore have temporarily increased the elevation of the confluence when these backwater observations were made. A $705-\mathrm{m}^{3} / \mathrm{s}$ flood occurred in January 1952, and a $570-\mathrm{m}^{3} / \mathrm{s}$ flood occurred in September 1952. Thus, this alone could easily have caused more than $0.5 \mathrm{~m}$ of uncertainty in our estimated 1952 and 1953 backwater elevations. In addition to these two physicalprocess constraints, the \pm 1 -m magnitude of uncertainty in the backwater elevations was also defined on the basis of repeated photographs. Hence, the elevations estimated for the backwater elevations had to be within the uncertainty range of those elevations inferred from historical photographs.

\section{Longitudinal Profile}

The first complete post-1926 longitudinal profile of the $22-\mathrm{km}$ study reach was constructed from detailed topographic maps that were made photogrammetrically from aerial photography on June 3, 1990 (Rkm 0 to 1.7), and on October 10, 1992 (Rkm 1.7 to 21). These maps were made for the Bureau of Reclamation Glen Canyon Environmental Studies (the precursor to the USGS Grand Canyon Monitoring and Research Center) and have a scale of 1:2,400 with a $0.5-\mathrm{m}$ contour interval. The horizontal datum of these maps is NAD 83 State Plane Arizona Central (1986). The vertical datum of 
these maps is the National Geodetic Vertical Datum of 1929 (NGVD 29); we thus converted elevations to NAVD 88 by using the NGS Coordinate Conversion and Transformation Tool (available at https://www.ngs.noaa.gov/NCAT) and the Geoid 18 model. The lower Little Colorado River was at base flow during the time of the aerial photography, so digitization of the contours crossing the river produced a base-flow longitudinal profile in a format consistent with that of the 1926 profile and subsequent 2002, 2013, and 2017 profiles. The 1992 longitudinal profile was thus constructed by digitizing the elevations of the river-crossing contours along the Zero Rock Centerline.

\section{2 and 2013 Longitudinal Profiles}

The most recent complete longitudinal profiles of the lower Little Colorado River were constructed by using remotesensing data collected in May and June 2002 and May 2013. These profiles were extracted from digital-surface models (DSMs) developed from overflight orthophotography. Both DSMs include 1-m resolution data for the Little Colorado River corridor from its confluence with the Colorado River to the reach above Blue Spring. The extracted profiles include water-surface elevations every $10 \mathrm{~m}$ along the $22-\mathrm{km}$ reach, deviating slightly from the Zero Rock Centerline only to avoid boulders and canyon walls. The profiles were filtered manually to remove the few elevation outliers arising from boulders in the channel or higher elevation points in canyon walls close to the water's edge. The Geoid 18 model was used to convert both the 2002 and 2013 longitudinal profiles from NAD 83 ellipsoid heights to NAVD 88 elevations.

\section{Longitudinal Profile}

The most recent longitudinal profile covers only part of our study reach. This profile was constructed by using base-flow water's-edge topographic points extracted at 50-m intervals from lidar and total-station survey data over the Rkm 0.4 to 1.8 reach that includes the LCR-mouth streamgage at Rkm 1.0.

\section{Repeat and Aerial Photography}

We compared historical ground-based oblique photographs with repeated photographs of the same site taken in 2013 and 2019 to determine changes in the elevations of the base-flow longitudinal profile at discrete locations along the Little Colorado River (fig. 2). We compared six photographs taken by Emery Kolb in 1909 and 1911 (Northern Arizona University, n.d.) with photographs taken by Michael Pillow in 2013 of the same areas. We also compared repeated photographs from 1932, 1948, the mid1950 s, and the early 1970s. The exact years of the 1950s photographs were not recorded in the archives, and the date of the 1970s photograph was recorded as 1971-1974. The repeat-photography process followed methods described by Webb (2010). We measured topographic features in historical photographs in the field in 2019 to estimate, with $0.5-\mathrm{m}$ uncertainty, the magnitude of water-surface-elevation changes at each photograph location.

Aerial photographs of the lower Little Colorado River taken in 1933-34 (Dean and Topping, 2019), 1951, 1952, 1954, and 1958 (USGS EarthExplorer [U.S. Geological Survey, n.d.] available at https://earthexplorer.usgs.gov) were compared with imagery from the 2013 overflight to identify locations in the channel with minimal elevation change. These stable locations were identified by the presence of mid-channel rocks (about 2 to $6 \mathrm{~m}$ in diameter) that were the same size and in the same orientation as shown in historical and 2013 aerial photographs. Locations that met these criteria were assigned an elevation for 2013 and an uncertainty of $\pm 2 \mathrm{~m}$ to account for the sizes of the rocks and the photographic resolution.

\section{Numerical-Modeling Methods}

We built models in the two-dimensional (2D) solvers FaSTMECH and SToRM within the International River Interface Cooperative (iRIC) framework (McDonald and others, 2005; Simões, 2009; Nelson and others, 2010) to determine a peak flow for each HWM set. We used (1) FaSTMECH, a quasi-steady two- and three-dimensional river-flow and morphodynamics solver developed by Jonathan Nelson of the USGS and (2) SToRM, an unsteady 2D unstructured-grid flow solver developed by Francisco Simões of the USGS. All iRIC solvers are available at https://i-ric.org/ en/solvers. We built models of the $1-\mathrm{km}$ reach of the Little Colorado River centered on the LCR-mouth streamgage from Rkm 0.5 to 1.5 (fig. 3). The downstream end of this reach could possibly be affected by Colorado River backwater because it is only $500 \mathrm{~m}$ upstream from the confluence of the Little Colorado and Colorado Rivers - a possibility evaluated in the "Discussion" section.

\section{Topography and Bathymetry}

Topography and bathymetry used in 2D models were measured by using the previously described terrestrial lidar scanning and total-station surveys from June 2017. Major changes in the longitudinal profile of the lower Little Colorado River occurred between 1926 and 2017, with most of them before 1992. Consequently, the bathymetry measured in 2017 was not used for simulating the peak flows of floods that may have occurred during the late 19th to middle 20th century. We modified the 2017 channel bathymetry on the basis of the surveyed base-flow longitudinal profile from 1926 to model these older floods; we refer to this modified bathymetry as the 1926 bathymetry. Because there is no evidence that base flow has changed over time, we used the estimated mean base-flow-wetted channel area of 15 square meters $\left(\mathrm{m}^{2}\right)$ from streamflow measurements made from 1990 through 2017 
to define the area of the pre-1990s base-flow channel. The channel shape in plan view was retained from the 2017 survey because the oldest aerial photographs without shadow (1951) showed a similar plan-view geometry. Although an earlier aerial-photograph set from 1933-34 described by Dean and Topping (2019) included this area, the model reach was in heavy shadow in these oldest aerial photographs. Most of the bars and banks had the same shape in 1951 as in 2017. Based on these conditions, the historical bathymetry used to simulate likely pre-1990s floods was constructed by lowering the elevation of the modern active channel to match the 1926 water-surface profile. Because only a negligible fraction of the streamflow of these larger pre-1990s floods would have been contained within the base-flow channel area, we approximated the channel-bed elevation in the model runs for these older floods as in the 1926 surveyed base-flow longitudinal profile. The historical 1926 bathymetry of the active channel was then merged with the modern 2017 overbank topography. This combination was appropriate because the higher elevation topography has not changed substantially over approximately the last 130 years, as evidenced by repeated photography and the preservation of strandlines from floods likely spanning the late 19th through late 20th century.

\section{D-Solver Methods}

Models were constructed in the USGS iRIC modeling framework by using both the FaSTMECH and the SToRM solvers. Procedures followed those laid out in solver manuals by Nelson and Simões and are available at https://i-ric.org/en/ solvers. Topography and bathymetry data collected in 2017 were used in calculating channel-grid elevations for simulating HWMs from the floods that likely occurred after most of the channel aggradation in the model reach. Topography data collected in 2017 were merged with the 1926 bathymetry, as described above, for simulating HWMs for the earlier floods. HWMs that may have been deposited during the period of greatest channel aggradation were simulated through the use of both the 1926 and 2017 bathymetry.

\section{Model Calibration}

We simulated flows in the FaSTMECH and SToRM solvers to calibrate roughness coefficients by comparing simulated water-surface elevation (that is, stage) at the LCR-mouth streamgage to those measured by the streamgage during three different peak flows (table 2). We calibrated the model by using the drag coefficient $\left(c_{d}\right)$, Nikuradse's roughness parameter $\left(z_{0}\right)$, and Manning's roughness coefficient $(n)$. FaSTMECH uses either $c_{\mathrm{d}}$ or $z_{0}$ to parameterize roughness, whereas SToRM uses Manning's $n$; we used Manning's $n$ for SToRM and $c_{\mathrm{d}}$ for FaSTMECH. After several model runs, we converted $c_{\mathrm{d}}$ to Manning's $n$ by using equation 1 to allow comparison between solvers. The best-fit roughness was determined for each simulated flow by running models at a constant streamflow and varying roughness until the simulated and measured stages at the LCR-mouth streamgage were equal (fig. 4).

$$
c_{\mathrm{d}}=n^{2} g / h^{1 / 3}
$$

where

$$
\begin{array}{cl}
c_{\mathrm{d}} & \text { is the drag coefficient, } \\
n & \text { is Manning's roughness coefficient, } \\
g & \text { is the gravitational acceleration ( } 9.807 \text { meters } \\
\text { per second squared), and }
\end{array}
$$

We chose roughness coefficients for FaSTMECH and SToRM on the basis of median Manning's $n$ among the three calibration model runs (table 2). For FaSTMECH, the median Manning's $n$ of 0.035 was converted to a $c_{\mathrm{d}}$ for each simulated case by using equation 1 and the appropriate value of $h$. For SToRM, the median Manning's $n$ used in all model runs was 0.028 .

Unless areas of increased roughness are inundated at higher stage, Manning's $n$ will be smaller at higher streamflows. In a wide channel with smooth banks, Manning's $n$ decreases with increasing stage or streamflow according to Manning's formulation of velocity (Chow, 1959). This is true for the three flows simulated for roughness calibration in FaSTMECH but not in SToRM. The Manning's $n$ values do not correlate to flow in the SToRM models; this may result from the limited range of streamflow in the three model runs. Unlike the larger historical floods we simulated for this study, these three calibration flows stay within the base-flow channel and near-channel overbank areas that are mostly devoid of vegetation. During the larger historical floods, the flow was interacting with more areas of vegetation and more large boulders that likely contributed to increased roughness, and thus offset the tendency for Manning's $n$ to decrease with increasing stage. Therefore, to include in the

Table 2. Flood peak flows used for roughness verification.

$\left[\mathrm{m}^{3} / \mathrm{s}\right.$, cubic meter per second; $n$, Manning's roughness coefficient; $z_{0}$, Nikuradse's roughness parameter; $c_{\mathrm{d}}$, drag coefficient $]$

\begin{tabular}{lccccc}
\hline \multicolumn{1}{c}{ Date } & Peak flow $\left(\mathbf{m}^{3} / \mathbf{s}\right)$ & FaSTMECH best-fit $\boldsymbol{n}$ & FaSTMECH best-fit $\boldsymbol{z}_{\mathbf{0}}$ & FaSTMECH best-fit $\boldsymbol{c}_{\mathrm{d}}$ & SToRM best-fit $\boldsymbol{n}$ \\
\hline $2 / 24 / 2005$ & 179 & 0.025 & 0.008 & 0.005 & 0.028 \\
$8 / 4 / 2010$ & 142 & 0.036 & 0.024 & 0.011 & 0.030 \\
$2 / 20 / 2017$ & 29.7 & 0.035 & 0.012 & 0.011 & 0.024 \\
\hline
\end{tabular}



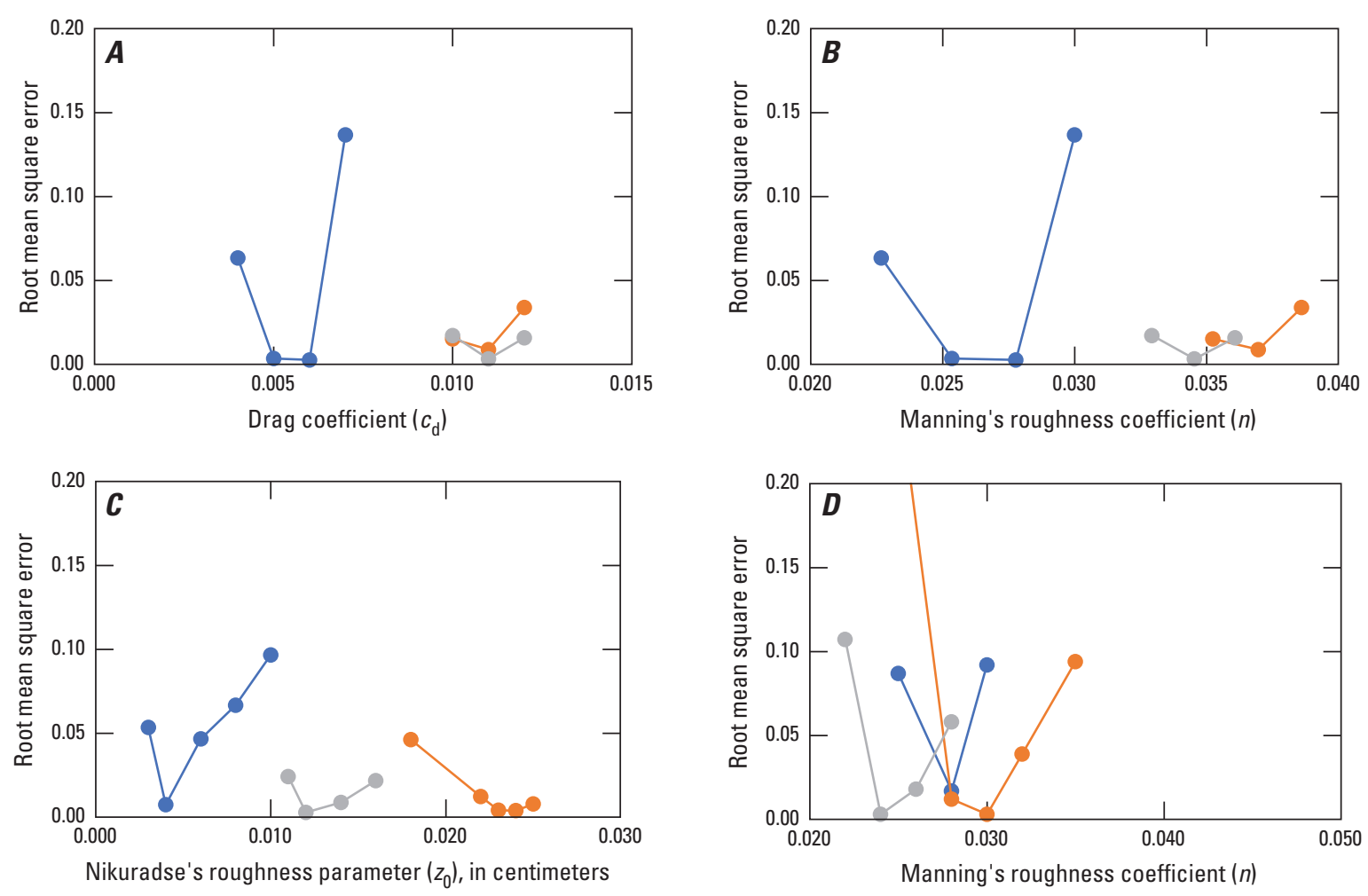

EXPLANATION

Streamflow, in cubic meters per second

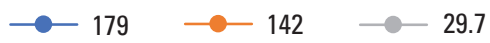

Figure 4. Plots showing model-roughness-calibration results calculated by using the FaSTMECH $(A$, $B, C$ ) and SToRM $(D)$ solvers for three floods with known water-surface profiles (peak flows of 179, 142, and 29.7 cubic meters per second). In all four calculations, the roughness coefficient with the lowest root mean square error was the best-fit roughness for that simulated flow.

calculations the influence of the progressive introduction of these rougher areas to the wetted perimeter during the larger historical floods, we held Manning's $n$ constant at 0.035 for all FaSTMECH model runs and at 0.028 for all SToRM model runs of these historical floods.

\section{D-Model Best-Fit Streamflow Methods}

We calculated a best-fit streamflow for each model run by iteration, comparing model-calculated water-surface elevations with surveyed HWM sets. For each set, all HWMs were moved 1 to $2 \mathrm{~m}$ toward the centerline to ensure that the points intersected active grid nodes and thus a comparison could be made. The elevations of these sets were not adjusted. We ran the model several times, iteratively varying the streamflow by using the "Compare with measured values" iRIC tool. This tool returns an RMSE between the measured water surface (defined by the HWMs) and the simulated water surface. The best-fit streamflow for each HWM set is the streamflow value with the minimum RMSE (fig. 5).

\section{FaSTMECH Modeling Methods}

We ran models for each HWM set in FaSTMECH by using parameters measured in the field and default parameters defined by the solver. Unique 2-m by $2-\mathrm{m}$ grids were developed for each HWM set, and the grids extended from the most upstream to the most downstream HWM for each set. The model grids were 200-m wide and extended well beyond the active channel up the colluvial and bedrock valley-side slopes to a position approximately $30 \mathrm{~m}$ above the channel bed. The stage at the downstream end of the model grid was held constant for each simulated flood and was determined by using the farthest downstream HWM in the set appropriate for that flood. Each model was run for 10,000 to 20,000 iterations to converge and stabilize.

The FaSTMECH solver requires user input for the values of many hydraulic parameters that cannot be measured in the field, and these parameter values were based on recommendations from the solver manual (Nelson, 2016). Models were run with the default value of 1 for the depth-weighting coefficient. 

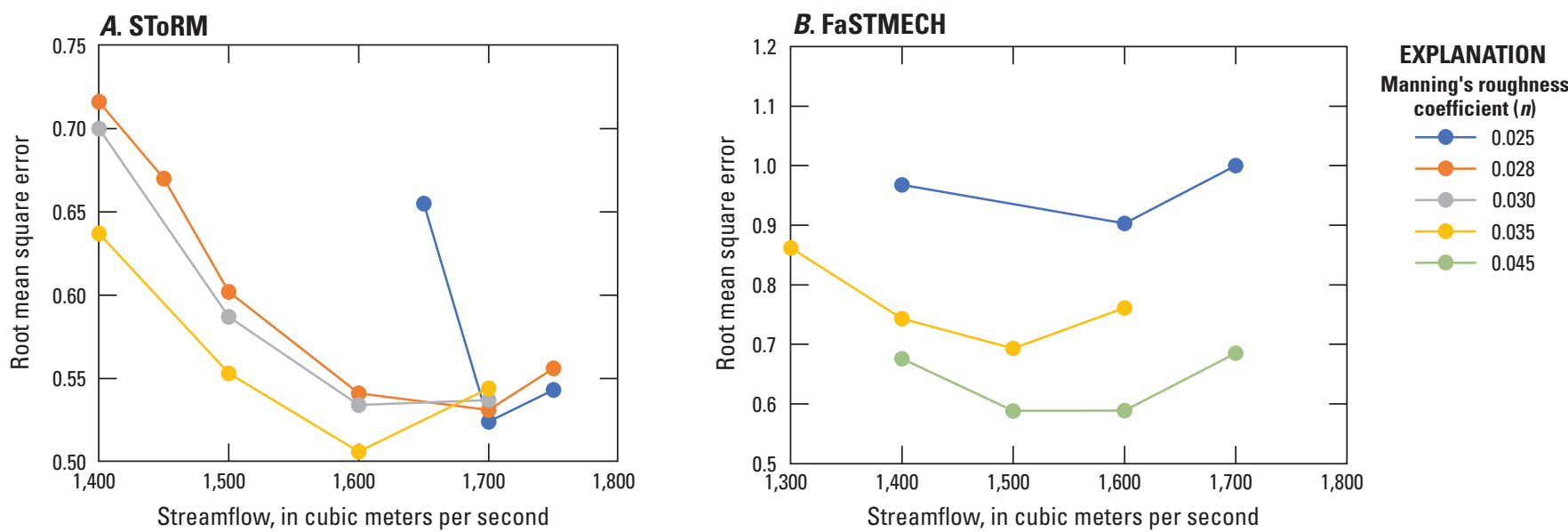

Figure 5. Plots showing the root mean square error for SToRM $(A)$ and FaSTMECH $(B)$ model runs for one simulated high-water mark (HWM) set D used to determine best-fit streamflow. The simulated streamflow that best fits the HWMs has the minimum root mean square error.

Lateral eddy viscosity, another important model parameter, was determined from mean flow depth and mean velocity by using an equation from the FaSTMECH solver manual. Other model coefficients were set at default values.

\section{SToRM Modeling Methods}

Models for each HWM set in SToRM were run by using parameters measured in the field and default parameters defined by the solver. Models had unique grids with triangular cells with areas less than $10 \mathrm{~m}^{2}$. Estimates of initial conditions were based on HWMs, and model runs were iterated until water-surface-elevation values stabilized and became independent of initial conditions. As with FaSTMECH, the downstream stage was held constant and determined for each simulated flood by using the HWM farthest downstream in the appropriate set.

\section{Results}

This section of the report provides the study results for the peak-flow history and changes in longitudinal profile of the lower Little Colorado River from the late 19th century to the early 21 st century.

\section{Attenuation and Traveltime of Flood Peaks}

The reconstruction of the peak-flow history of the lower Little Colorado River required evaluation of the downstream attenuation and traveltimes of peak flows during floods because records from streamgages in the Little Colorado River upstream from the study reach or from streamgages downstream on the Colorado River were used. Both the attenuation and traveltime of flood peaks in the Little Colorado River between the Grand Falls, near-Cameron, and LCR-mouth streamgages as well as the attenuation of Little Colorado River floods after merging with the Colorado River (that is, attenuation of these flood peaks between the confluence and the Grand Canyon streamgage) were considered. The published USGS streamflow values (U.S. Geological Survey, 2019) have uncertainties of approximately 5 percent, so the attenuations of peak flows of less than 5 to 10 percent between streamgages are difficult to constrain.

The attenuation of flood peak flows from the nearCameron streamgage to the LCR-mouth streamgage was evaluated by using data from 10 floods during 1993-2017. The mean traveltime for flood peaks with flows between 108 and $233 \mathrm{~m}^{3} / \mathrm{s}$ was approximately 7.5 hours, and the attenuation of peak flows averaged 8 percent among these 10 events (table 3). We also compared the total volumes of floods between the near-Cameron and LCR-mouth streamgages for cases where the overall shape of the hydrograph was similar at both streamgages - that is, no additional peaks or bulges in the hydrograph shape. This comparison allowed the selection of floods where the tributary contribution of water between the streamgages was negligible. In addition, floods were selected during which streamflow measurements were made from the cableway at the near-Cameron streamgage, thus ensuring that only floods with the most accurate streamflow values were chosen. We used a total of four floods: one in January 1993, two in February 2005, and one in August 2010 with peak flow values at the near-Cameron streamgage of $233,144,184$, and $142 \mathrm{~m}^{3} / \mathrm{s}$, respectively. The attenuation of peak flow between the near-Cameron and LCR-mouth streamgages for these four floods ranged from 0 to 4 percent (table 3 ) and the difference in volume (after correcting for constant input from the Blue Spring complex) ranged from 1 to 13 percent. The attenuation 
Table 3. Traveltimes and attenuation of flood peak flows between the near-Cameron and LCR-mouth streamgages for 10 floods during the period 1993 through 2018.

[LCR, Little Colorado River; MST, Mountain Standard Time; $\mathrm{m}^{3} / \mathrm{s}$, cubic meter per second; \%, percent]

\begin{tabular}{|c|c|c|c|c|c|}
\hline \multicolumn{2}{|c|}{ Near-Cameron streamgage (09402000) } & \multicolumn{2}{|c|}{ LCR-mouth streamgage (09402300) } & \multirow{2}{*}{$\begin{array}{c}\text { Traveltime } \\
\text { (hours:minutes) }\end{array}$} & \multirow{2}{*}{ Attenuation } \\
\hline Date and time (MST) of peak & Peak flow $\left(\mathrm{m}^{3} / \mathrm{s}\right)$ & Date and time (MST) of peak & Peak flow $\left(\mathrm{m}^{3} / \mathrm{s}\right)$ & & \\
\hline 1/8/1993 12:15 & 233 & 1/8/1993 18:00 & 222 & 05:45 & $4 \%$ \\
\hline 7/15/2004 5:15 & 135 & 7/15/2004 12:00 & 112 & $06: 45$ & $17 \%$ \\
\hline 1/4/2005 3:15 & 144 & 1/4/2005 10:15 & 141 & 07:00 & $2 \%$ \\
\hline 2/17/2005 9:45 & 144 & 2/17/2005 22:15 & 143 & $12: 30$ & $1 \%$ \\
\hline 2/23/2005 20:45 & 184 & $2 / 24 / 20054: 30$ & 179 & $07: 45$ & $3 \%$ \\
\hline 1/22/2010 4:45 & 133 & $1 / 22 / 201012: 45$ & 122 & 08:00 & $8 \%$ \\
\hline 8/7/2010 15:30 & 142 & 8/7/2010 22:30 & 142 & 07:00 & $0 \%$ \\
\hline 9/11/2012 21:20 & 169 & 9/12/2012 5:15 & 109 & 07:55 & $35 \%$ \\
\hline $7 / 26 / 201322: 30$ & 170 & $7 / 27 / 20135: 30$ & 151 & 07:00 & $11 \%$ \\
\hline \multirow[t]{2}{*}{ 10/4/2018 2:00 } & 108 & 10/4/2018 9:15 & 108 & 07:15 & $0 \%$ \\
\hline & & & Mean & 07:41 & $8 \%$ \\
\hline
\end{tabular}

of peak flow between the near-Cameron and the LCR-mouth streamgages was therefore minimal for the floods examined. Because peak-flow attenuation depends on flood magnitude (Lighthill and Whitman, 1955), floods of larger magnitude would thus exhibit either similar minimal or perhaps negligible attenuation between these streamgages.

Because we used the streamflow record from the Grand Falls streamgage to reconstruct the peak-flow history of the lower Little Colorado River between November 1925 and June 1947 (the period before establishment of the near-Cameron streamgage), we also needed to evaluate the attenuation of flood peak flow between the Grand Falls and LCR-mouth streamgages. This evaluation required combining the results in the previous paragraph for the attenuation of flood peaks between the near-Cameron and LCR-mouth streamgages with the results from Dean and Topping (2019) for the pre-1960 attenuation of flood peaks between the Grand Falls and nearCameron streamgages. Before the onset of major channel change in the Little Colorado River between the Grand Falls and near-Cameron streamgages around 1960, the attenuation of peak flow between these streamgages averaged only 2.4 percent (Dean and Topping, 2019). Thus, the pre-1947 attenuation of peak flow between the Grand Falls and nearCameron streamgages and the post-1947 attenuation of peak flow between the near-Cameron and LCR-mouth streamgages were both negligible. Therefore, we reconstructed the part of the peak-flow history of the lower Little Colorado River from November 1925 to present by using the published peak flows of pre-1947 floods at the Grand Falls streamgage and the post-1947 floods at the near-Cameron streamgage without any adjustment for attenuation.
As in the analysis of the attenuation of flood peaks, we used results from Dean and Topping (2019) to estimate the pre-1947 traveltime of flood peaks between the Grand Falls and near-Cameron streamgages, and the results in table 3 to estimate the traveltime of flood peaks between the nearCameron and LCR-mouth streamgages. The traveltimes of flood peaks from the Grand Falls streamgage to the nearCameron streamgage during the pre-1965 floods ranged from 0.3 to 0.6 days (Dean and Topping, 2019) or 7 to 14 hours, with a mean of approximately 10 hours. This traveltime, in combination with the mean of approximately 8 hours for flood peaks between the near-Cameron and LCR-mouth streamgages, indicates a mean traveltime of approximately 18 hours for pre-1947 flood peaks between the Grand Falls and LCR-mouth streamgages.

Reconstruction of the peak-flow history for the period between the October 1922 establishment of the Grand Canyon streamgage and the November 1925 establishment of the Grand Falls streamgage required evaluation of the attenuation of Little Colorado River flood peaks downstream in the Colorado River. We used data from the Grand Falls, Lees Ferry, and Grand Canyon streamgages to constrain the attenuation and traveltimes in the Colorado River of extremely large Little Colorado River flood peaks in 1923 and 1929. We then used data from the near-Cameron, Lees Ferry, and Grand Canyon streamgages to constrain the attenuation and traveltimes of Little Colorado River floods in 1947 and 1954 during periods of documented steadier flow in the Colorado River. Although the peak flows during the 1947 and 1954 floods were lower than the peak flows during the 1923 and 1929 floods, the 1947 and 1954 floods allowed for a more 
accurate estimation of attenuation because of the reduced variation in Colorado River streamflow. In addition, because only negligible peak-flow attenuation has been documented for floods within the Little Colorado River, all of the attenuation values calculated in these analyses were assumed to have occurred within the Colorado River. Finally, we used the streamflow-routing models of Wiele and Smith (1996) and Wiele and Griffin (1997) to estimate the peak attenuation and hydrograph of a large flood in the Little Colorado River that occurred in December 1923.

The only other large tributary that enters the Colorado River between the Lees Ferry and Grand Canyon streamgages is the Paria River (fig. 1). Data from the Paria River streamgage indicate that no floods occurred in the Paria River during the 1929, 1947, and 1954 Little Colorado River floods. Although the Paria River streamgage was established one month after the large September 1923 Little Colorado River flood, the USGS did not record evidence of any recent large Paria River floods when it established the streamgage. Thus, any influence of the Paria River on the streamflow data at the Grand Canyon streamgage was considered unlikely and omitted from these analyses.

Our empirical analyses of the 1923, 1929, 1947, and 1954 Little Colorado River floods indicate that an attenuation of about 20 percent in peak flow is plausible for these floods in the 45-km-long segment of the Colorado River between the Little Colorado River confluence and the Grand Canyon. The reconstruction of the hydrograph of a large Little Colorado River flood in December 1923 by using the models of Wiele and Smith (1996) and Wiele and Griffin (1997) indicates that larger (approximately 37 percent) attenuation is possible for large short-duration floods. The peak flow of the September 1923 Little Colorado River flood was likely attenuated by approximately 14 percent along this segment of the Colorado River. The peak flow of this flood was estimated as approximately $3,400 \mathrm{~m}^{3} / \mathrm{s}$ at the Grand Falls streamgage on the basis of a rating-curve extrapolation that used HWMs because the streamgage had not yet been established. The peak of this flood was observed at 9:40 Mountain Standard Time (MST) on September 19, 1923, at Cameron, Ariz. (a photograph of the flood peak is in Dean and Topping, 2019), and caused the streamflow at the Grand Canyon streamgage to peak at 18:02 MST on September 19, 1923. This peak in streamflow was approximately $2,930 \mathrm{~m}^{3} / \mathrm{s}$ greater than the traveltimeadjusted streamflow at the Lees Ferry streamgage.

The peak flow of the April 1929 Little Colorado River flood likely attenuated by approximately 15 percent in the Colorado River. The peak flow of this flood was measured as $1,430 \mathrm{~m}^{3} / \mathrm{s}$ by a current meter at the Grand Falls streamgage at 17:20 MST on April 5, 1929. The shapes of the flood hydrographs from the Grand Falls and Grand Canyon streamgage changed very little. This flood peaked at the Grand Canyon streamgage at 6:37 MST on April 6, 1929, causing an increase in streamflow of approximately $1,210 \mathrm{~m}^{3} / \mathrm{s}$ greater than the traveltime-adjusted streamflow at the Lees Ferry streamgage. This flood emerged from the Little Colorado River into the rising limb of a Colorado River flood, and this interaction may have decreased the attenuation of this flood in the Colorado River.

The peak flows of the August 1947 and September 1952 Little Colorado River floods likely attenuated by approximately 21 and 23 percent, respectively, in the Colorado River. The 1947 flood had a peak flow of $619 \mathrm{~m}^{3} / \mathrm{s}$ at the near-Cameron streamgage at 8:40 MST on August 9, 1947, and peaked at the Grand Canyon streamgage at 16:34 MST on August 9, 1947, causing an increase of approximately $490 \mathrm{~m}^{3} / \mathrm{s}$ over the traveltime-adjusted streamflow at the Lees Ferry streamgage. The 1952 flood had a peak flow of $570 \mathrm{~m}^{3} / \mathrm{s}$ at the near-Cameron streamgage at 9:43 MST on September 21, 1952, and peaked at the Grand Canyon streamgage at 18:40 MST on September 21, 1952, causing an increase of approximately $440 \mathrm{~m}^{3} / \mathrm{s}$ over the traveltime-adjusted streamflow at the Lees Ferry streamgage.

\section{Peak-Flow History of the Lower Little Colorado River}

Floods in the Little Colorado River detected at the Grand Canyon streamgage (September and December 1923) and measured at the Grand Falls $(1929,1938)$ and near-Cameron streamgages $(1952,1972,1993,2002)$ are used herein to reconstruct the sequence of peak flows in the study reach in the lower Little Colorado River. Floodwaters generally erase evidence of previous flows at the same or lower water elevations, so there is a time series of preservable peak flows in any river. In cases where the most recent flood produced the largest peak flow, this time series will exhibit as a single strandline from only that flood. In contrast, in cases where the peak-flow magnitude has declined over time, as in the Little Colorado River, this time series will exhibit as multiple strandlines associated with progressively lower peak stages with time (fig. 6). The months, years, and likely peak flows in this time series of known preservable peak flows in the lower Little Colorado River are shown in table 4. The peak flows of all flows except the December 1923 event were measured or estimated (for the September 1923 flow) at streamgages on the Little Colorado River. Thus, the peak flows of these floods were not adjusted for attenuation, as described in the "Methods" section.

The likely December 1923 Little Colorado River flood was detected as a peak of $1,620 \mathrm{~m}^{3} / \mathrm{s}$ at 16:43 MST on December 28 at the Grand Canyon streamgage. This peak flow corresponds to an increase of approximately $1,460 \mathrm{~m}^{3} / \mathrm{s}$ greater than the traveltime-adjusted streamflow at the Lees Ferry streamgage. Although a small rise occurred at the Lees Ferry streamgage on December 29, the streamflow at this streamgage on December 27 and 28 was steady. The Paria River is the only other possible source for the flood detected at the Grand Canyon streamgage on December 28, but was at or near base flow at the Paria River streamgage (fig. 1) on 


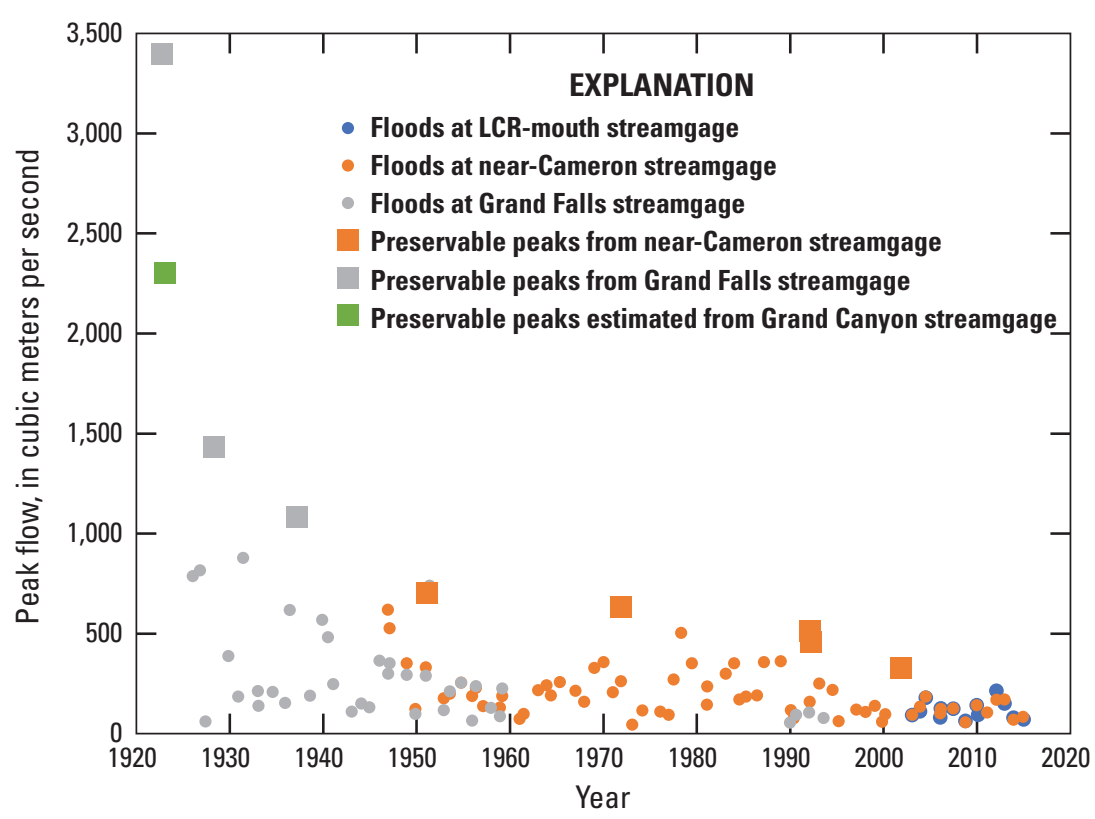

Figure 6. Plot showing the peak-flow record of the lower Little Colorado River constructed from the gaging records at the LCR-mouth streamgage, the nearCameron streamgage, and the Grand Falls streamgage, and estimated by using a streamflow-routing model from the Grand Canyon streamgage for 1923-2017. The sequence of peak flows with progressively decreasing streamflow-preservable peaks - is denoted by the large squares. Note that floods larger than approximately 400 cubic meters per second $\left(\mathrm{m}^{3} / \mathrm{s}\right)$ become rare after 1952, and floods larger than approximately $200 \mathrm{~m}^{3} / \mathrm{s}$ become extremely rare after the early 1990s. LCR, Little Colorado River.
Table 4. Preservable peak flows in the lower Little Colorado River. $\left[\mathrm{m}^{3} / \mathrm{s}\right.$, cubic meter per second; $\sim$, approximately]

\begin{tabular}{lc}
\hline Month and year of flood peak & $\begin{array}{c}\text { Peak flow in the lower Little } \\
\text { Colorado River }\left(\mathbf{m}^{\mathbf{3}} \mathbf{s} \mathbf{s}\right)\end{array}$ \\
\hline September 1923 & 3,400 \\
December 1923 & $\sim 2,300$ \\
April 1929 & 1,430 \\
March 1938 & 1,080 \\
January 1952 & 705 \\
October 1972 & 634 \\
January 1993 & 515 \\
February 1993 & 459 \\
September 2002 & 326 \\
\hline
\end{tabular}

this date. Reconstruction of the hydrograph of the December 1923 flood by using the models of Wiele and Smith (1996) and Wiele and Griffin (1997) indicates that the peak flow of this flood, assumed to be of a short duration, was approximately $2,300 \mathrm{~m}^{3} / \mathrm{s}$ as it emerged from the Little Colorado River. This reconstruction used the observed Colorado River streamflows at the Lees Ferry streamgage, iteratively adding streamflow hydrographs from the Little Colorado River at the confluence, and then routed these combined flows downstream to the Grand Canyon streamgage. The final estimated hydrograph of the December 1923 Little Colorado River flood was thus the hydrograph that was in closest agreement with the measured hydrograph at the Grand Canyon streamgage.

There is evidence of other large floods in the Little Colorado River upstream from the study reach during the late 1800s and early 1990s - floods occurring before the well-documented post-1923 part of its peak-flow history. Thus, given that some of these floods may have had larger peak flows than the September 1923 flood, strandline(s) from these older floods may be preserved in the lower Little Colorado River study reach (fig. 6). Bell (1937) documented the occurrence of a "super-flood" in 1888, quite possibly the largest historical flood in the Little Colorado River. Bell (1937) also documented other large precipitation-driven floods in 1905, 1908, 1911, 1916, and 1919. In addition, Dean and Topping (2019) described a total of 23 dam failures between 1876 and 1900 in upstream reaches of the Little Colorado River Basin in addition to the failure of the largest dam ever constructed on the main-stem Little Colorado River-the Lyman Lake Dam in 1915. All of these dam failures produced floods, with the 1915 dam failure known to have produced an especially large flood.

\section{Changes in the Longitudinal Profile}

The complete longitudinal profiles from 1992, 2002, and 2013 differ in local elevation by less than $1 \mathrm{~m}$ from each other over most of the study reach, and therefore demonstrate only negligible change between the years 1992 and 2013, given the uncertainty in the measurements, over most of the longitudinal profile in the $22-\mathrm{km}$ study reach. The two exceptions to this general post-1992 stability occurred at Rkm 14.2, the location of Chute falls, and at Rkm 20.8, at Blue Spring; at both of these locations, measurable post-1992 aggradation has occurred. At Rkm 14.2, the base-flow longitudinal profile aggraded by approximately $0.8 \mathrm{~m}$ between 1992 and 2002 and by another $0.8 \mathrm{~m}$ between 2002 and 2013. At Rkm 20.8, the base-flow longitudinal profile aggraded by $0.6 \mathrm{~m}$ between 1992 and 2002 and by another $0.9 \mathrm{~m}$ between 2002 and 2013. The remainder of the $22-\mathrm{km}$ reach was the same within the uncertainty of measurements for the 1992, 2002, and 2013 
profiles. The 1992-2013 profiles, however, are generally very different from the profile surveyed in 1926, indicating major amounts of incision in the upstream part of the reach and aggradation in the downstream part of the reach between 1926 and 1992.

Much of the incision and aggradation observed throughout the study reach occurred between 1926 and the 1950 s, as indicated by a comparison between the 1950s and 2013 aerial photographs. Multiple mid-channel rocks protrude through the base-flow water surface in aerial photographs from 1951, 1952, 1954, 1958, and 2013 at 15 locations between Rkms 2.5 and 20.8. Thus, only minimal (that is, less than $\pm 2 \mathrm{~m}$ ) changes in the base-flow water-surface elevation have occurred at these 15 locations since at least 1951. The mid-channel rocks downstream from Rkm 4 were not present in the oldest 1933-34 aerial photograph. We did not have the 1933-34 aerial photographs upstream from Rkm 4, so we could not determine whether the mid-channel rocks identified in the 1951-2013 aerial photographs in this part of the study reach were present in 1933-34. Profiles are shown in figure 7 together with (1) 1950s observations of the headward extent and elevations of backwater, (2) elevations from repeat photographs elaborated upon in the "Discussion" section, and (3) locations where mid-channel rocks in aerial photographs indicate negligible to minimal change in the base-flow watersurface elevation since at least the 1950 s.

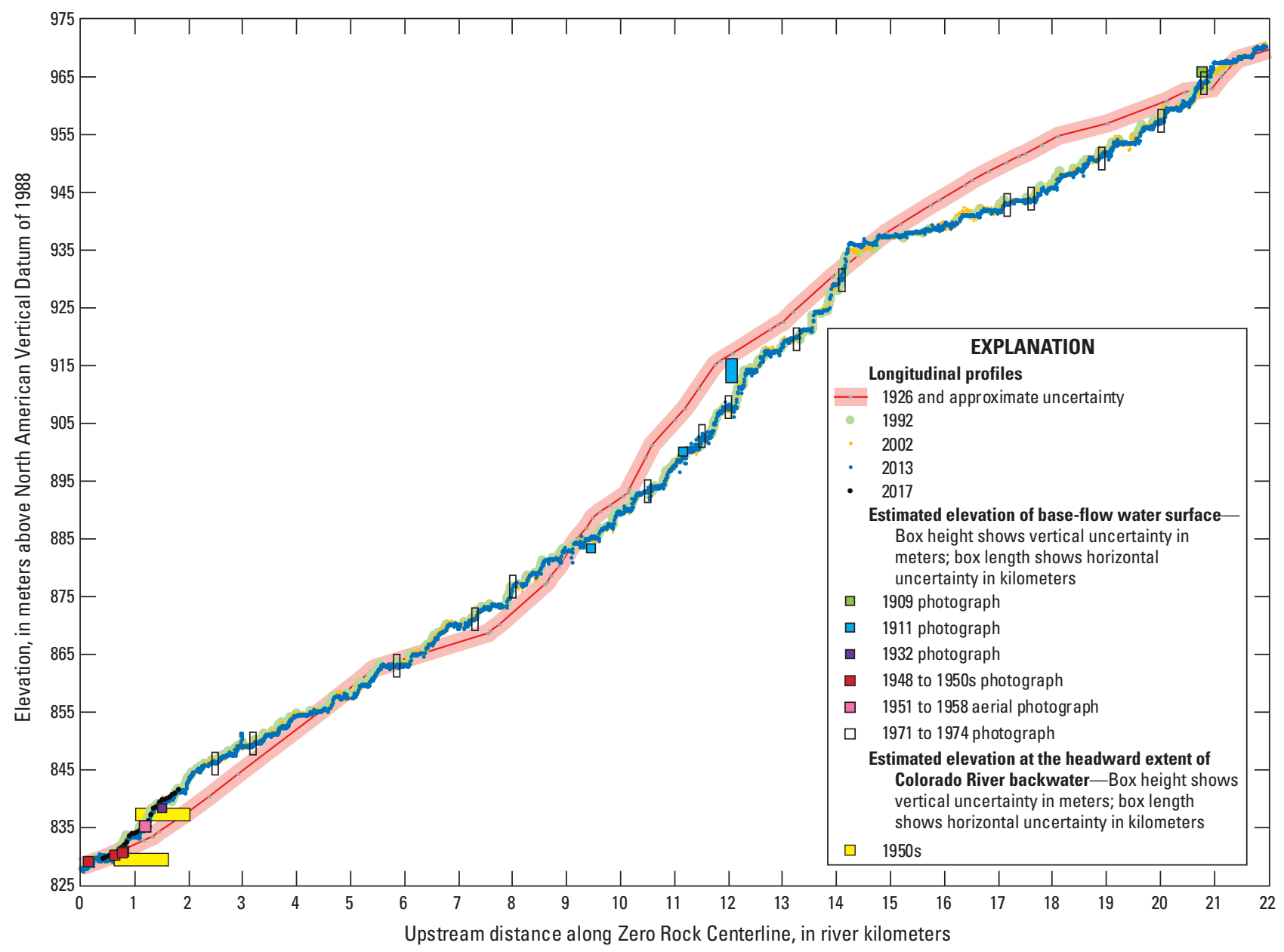

Figure 7. Longitudinal profiles of the lower Little Colorado River from 1926, 1992, 2002, 2013, and 2017. Estimated elevations of the base-flow water surface in 1909, 1911, 1932, 1948-1950s, and 1971-1974 historical photographs, estimated elevations of the baseflow water surface in 1951-1958 aerial photographs, and estimated elevations of the headward extents of Colorado River backwater pools in the 1950s are shown as squares whose sizes represent the approximate uncertainty in elevation and location. The \pm 1 -meter magnitudes of the uncertainties in the elevations reconstructed from the backwater observations near river kilometers (Rkms) 1.1 and 1.5 were determined, in part, so that these water-surface elevations were consistent with those estimated from 1950s photographs at Rkms 0.64 and 0.78 and from a 1932 photograph at Rkm 1.5. Multiple boulders in the 1932 photograph are visible in the same locations and orientations in our 2019 photograph, thus indicating that no substantial post-1932 scour and fill occurred at Rkm 1.5 and showing the post-1932 water-surface elevation upstream from Rkm 1.5 to be no lower than it was in the 1932 photograph. 


\section{Classification of High-Water Marks}

We assigned the HWMs in the surveyed reach to different sets for flow modeling by using a multistep detrending, binning, and segregation process. The HWMs on each bank were analyzed separately. Each HWM set represents a strandline deposited by either one or multiple floods reaching the same elevation (Koenig and others, 2016). We used two detrending methods based on the stages of the floods that produced the HWM sets. First, the two lowest and therefore most recent HWM sets were detrended on each bank along the 2017 base-flow water-surface profile (detrending line 1 on figs. 8 and 9). HWM set A was defined as all HWMs within $2.4 \mathrm{~m}$ of the 2017 base-flow longitudinal profile. Set B was defined as all HWMs from 2.4 to $2.8 \mathrm{~m}$ above the 2017 base-flow profile. Because these two sets were deposited during relatively recent floods, sets A and B formed distinct strandlines that were obvious in the field and thus required minimal interpretation. The higher elevation, older HWM sets, however, formed less-distinct strandlines that did not track as closely with the longitudinal variations in the 2017 base-flow water-surface profile, most likely because the water-surface profile is more linear at higher stages. These higher elevation sets on each bank were therefore detrended by using the slope of a line fit to the uppermost HWMs within the remaining data that formed distinct and obvious strandlines (detrending line 2 on figs. 8 and 9). Note that there was one group of the oldest HWMs on the left bank above this line.

After detrending, we used a binning process to segregate the higher elevation HWMs (that is, those above sets A and B) into different sets. This process was required because some of the older HWMs, particularly on the left bank, formed strandlines that were relatively diffuse. These diffuse strandlines most likely arose from the complication of flood flow interacting with the complex geometry of the sandstone ledges on this bank (fig. 10). The left bank in the surveyed reach is characterized by steep bedrock with deeply incised ledges and overhangs. These features may trap driftwood, causing more deposition on prominent ledges and less deposition at elevations without ledges. If the peak stage from a flood does not align properly with a ledge feature, the deposits from the flood may thus be trapped under an overhanging ledge below the peak stage, or possibly above the peak stage in areas on the outside of a curve in the stream where local water surface can be higher than that in straight reaches. The right bank has a simpler slope geometry with few ledges and overhangs to enhance topographic control of driftwood deposition. For this reason, we weighted the binned right-bank HWM more heavily when we segregated the HWMs into different sets.

The binning and segregation process for each bank proceeded as follows. The HWMs above sets A and B were placed into $0.3-\mathrm{m}$ bins on the basis of their vertical distance from detrending line 2 . The $0.3-\mathrm{m}$ bin size for HWM elevations was chosen on the basis of the uncertainty regarding the elevation of woody debris emplaced during individual floods. Histograms counting the number of HWMs in each bin were then constructed for each bank (fig. 11). The troughs between the peaks in these histograms were then used to segregate the HWMs into different sets. After this initial segregation, the HWMs in some of the bins in the troughs

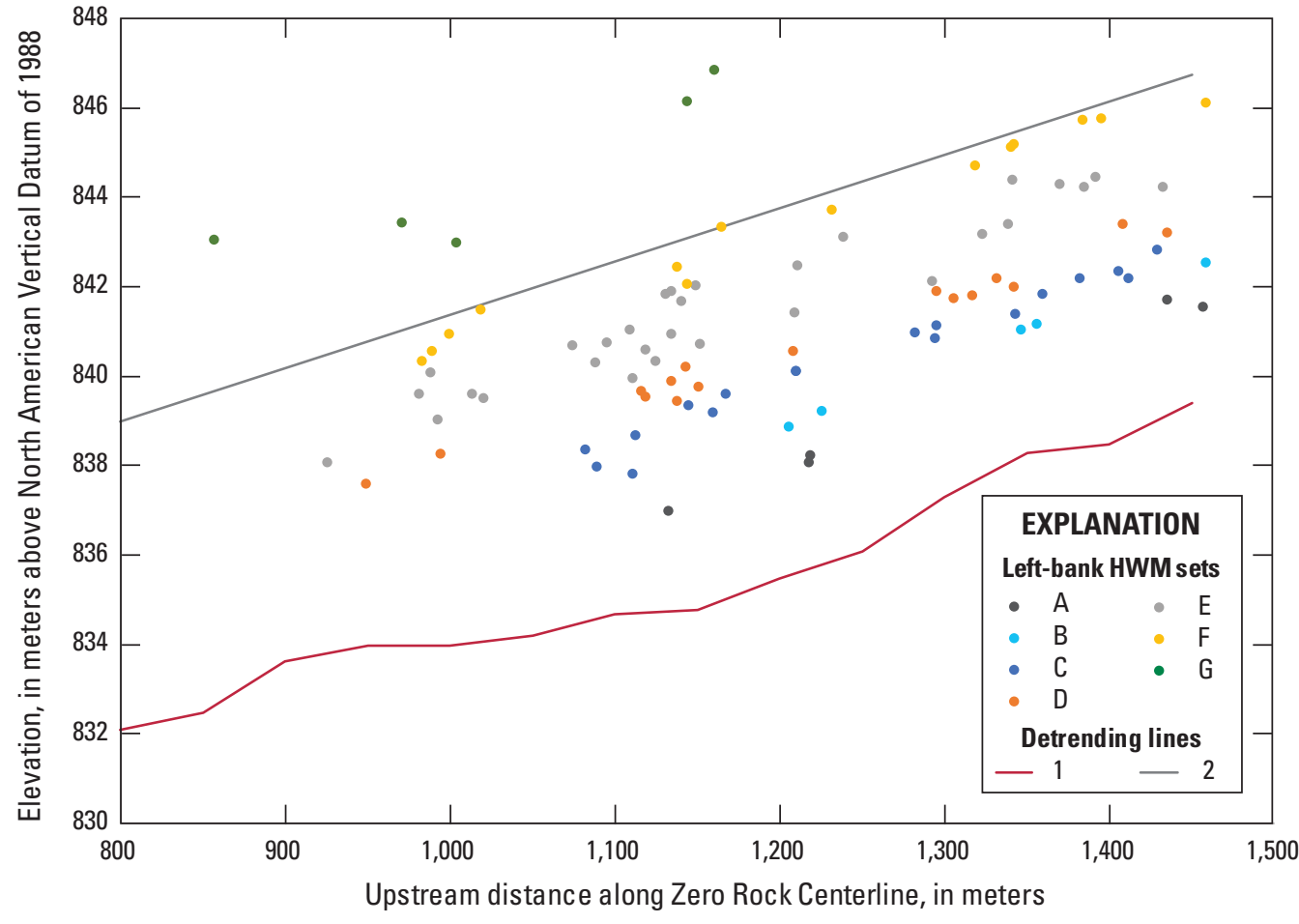

Figure 8. Plot of high-watermark (HWM) elevations on the left bank of the Little Colorado River versus distance along the Zero Rock Centerline and differentiated into sets (A-G) along detrending lines 1 and 2 . 


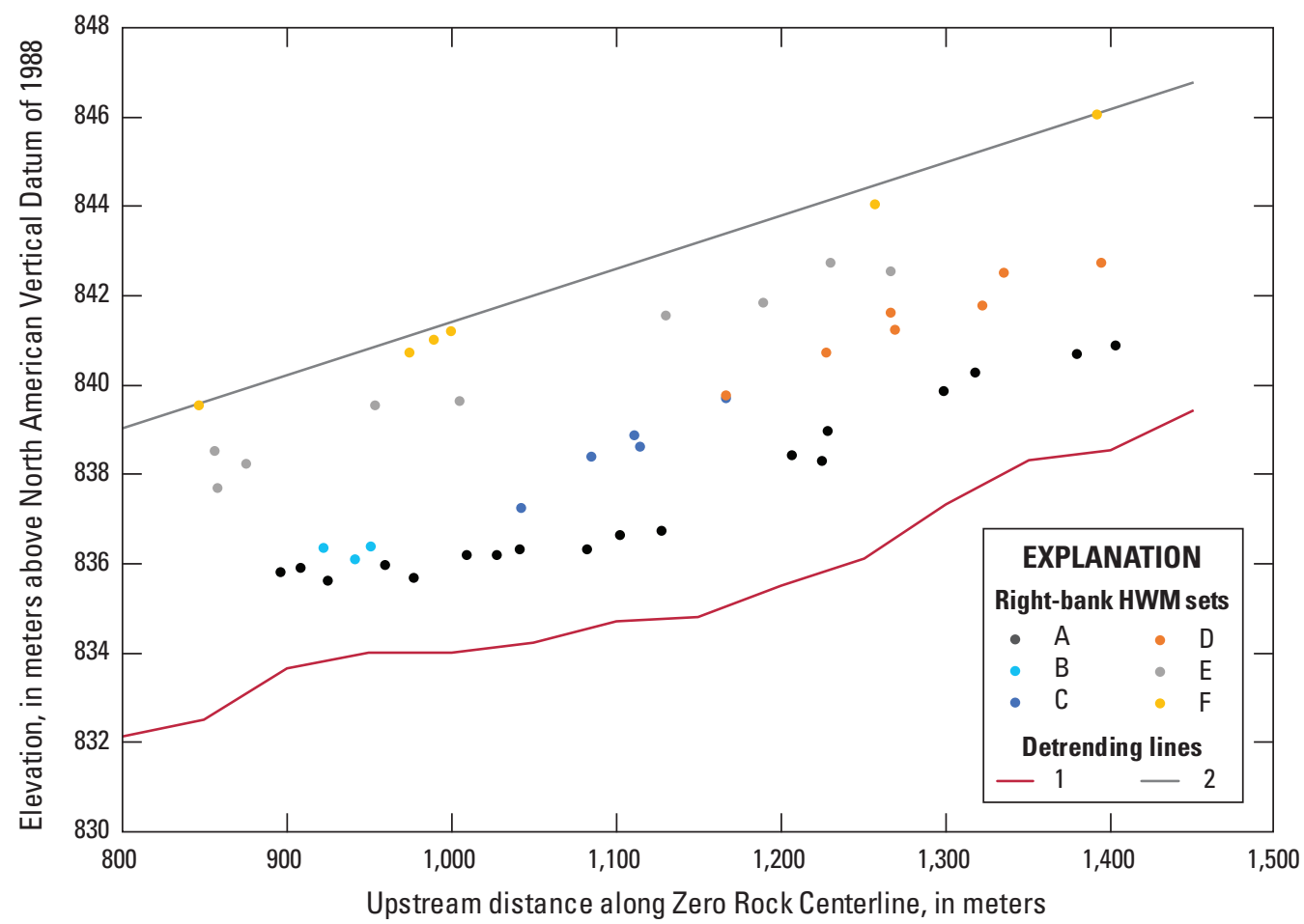

Figure 9. Plot of high-watermark (HWM) elevations on the right bank of the Little Colorado River versus distance along the Zero Rock Centerline and differentiated into sets $(A-G)$ along detrending lines 1 and 2.

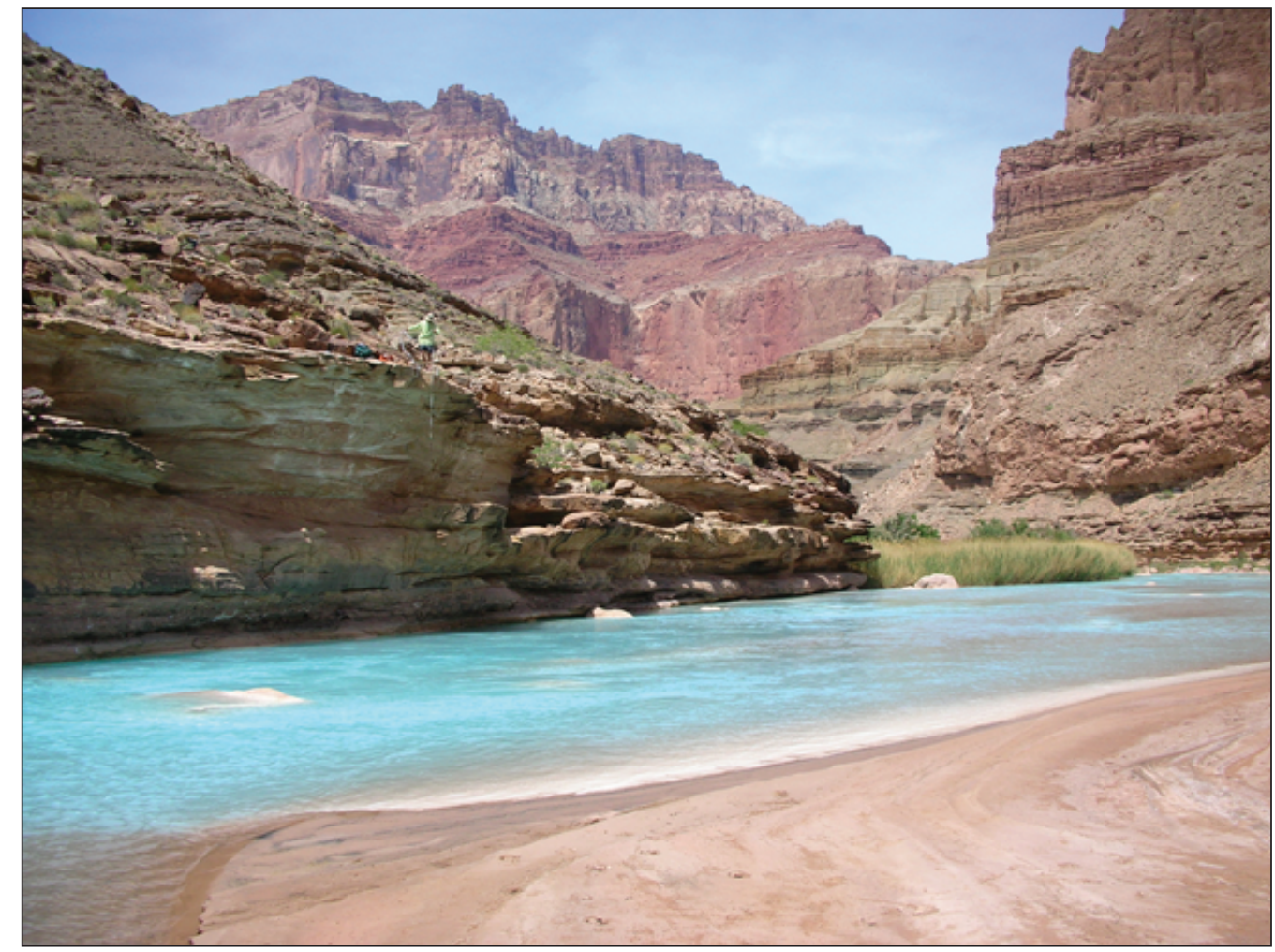

Figure 10. Photograph taken downstream from the complex geometry of ledges of Cambrian-age Tapeats Sandstone of Tonto Group on the left bank of the Little Colorado River near the LCR-mouth streamgage in the reach surveyed in June 2017. Photograph taken from sandbar on right side of base-flow channel. A U.S. Geological Survey hydrologist is standing at the gaging-station downwardlooking-radar stage sensor. The complex ledge geometry extends upstream approximately 120 meters from the view in this photograph in a section that includes large sloping ledges where water-surface elevations increase disproportionately during floods. The more gently sloping right bank, with fewer ledges, is to the right of the view in this photograph. LCR, Little Colorado River. 

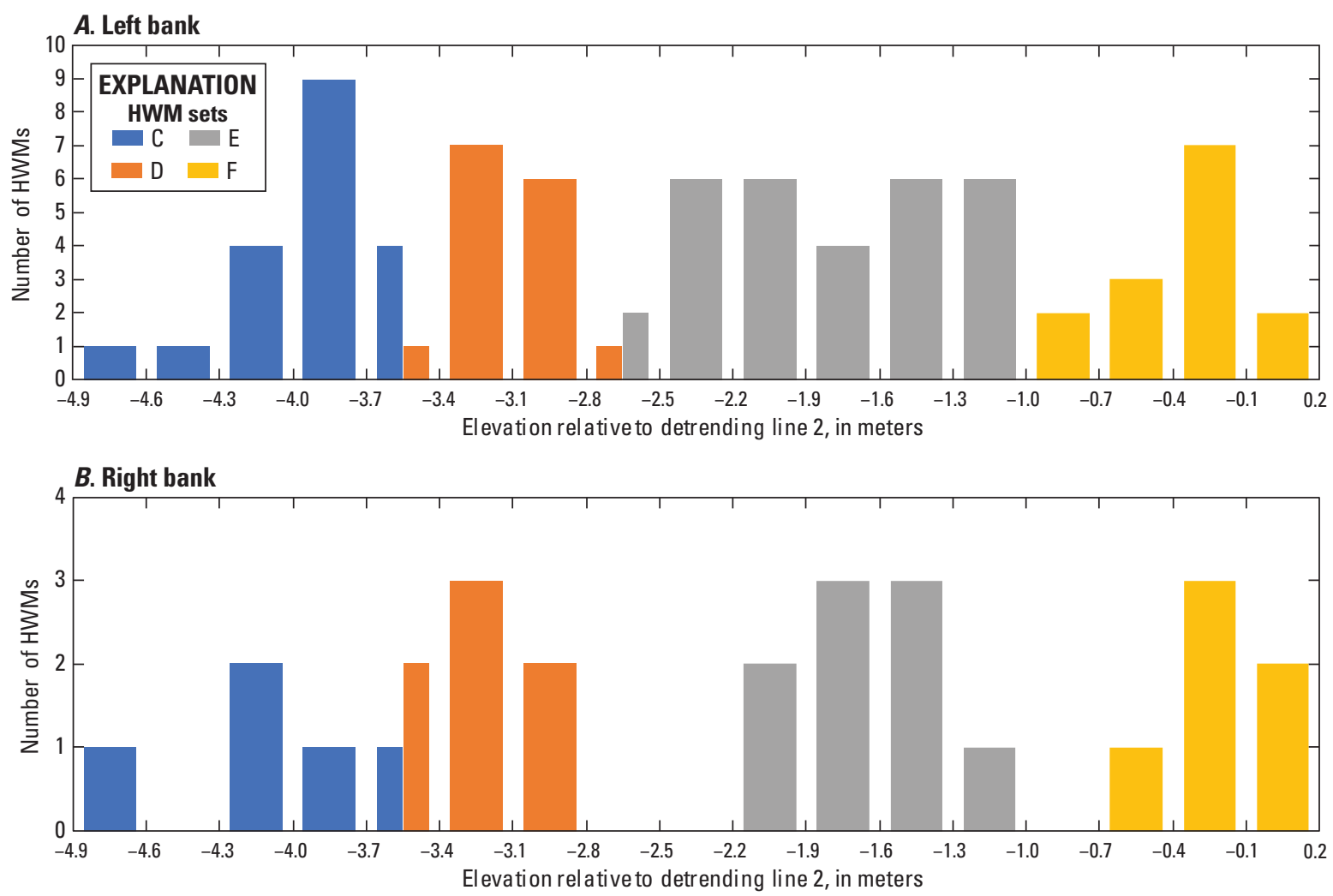

Figure 11. Histograms of high-water marks (HWMs) binned by elevation relative to detrending line 2 (figs. 8 and 9 ) for left $(A)$ and right $(B)$ banks of the Little Colorado River. Positive relative elevation ( 0.2 on the right end of the graph) indicates that the HWM is above detrending line 2. Bin size is 0.3 meter, and the numbers on the $\mathrm{x}$-axis are the lower and upper bounds of each bin. Interpreted HWM sets $\mathrm{C}$ through $\mathrm{F}$ are distinguished by color; HWM set $\mathrm{G}$ is excluded because its HWMs are present only on the left bank and all points in set $\mathrm{G}$ are more than 1.5 meters above detrending line 2.

were subdivided into separate sets based on their relative positions in figure 8. By this process, we assigned the HWMs above sets $\mathrm{A}$ and $\mathrm{B}$ to four different and relatively distinct sets on the more gently sloping right bank ( $\mathrm{C}$ through $\mathrm{F}$ ). We assigned the HWMs above sets A and B on the complicated ledge- and overhang-dominated left bank to the same four sets ( $\mathrm{C}$ through $\mathrm{F}$ ) plus one additional set $(\mathrm{G})$.

Our binning and segregation process placed the HWM sets into similar elevation bins on each bank, except for set $\mathrm{G}$, which is preserved only on the left bank. In addition, the bins of maximum HWM occurrence (the peaks in fig. 11) associated with each set are at identical elevations on each bank relative to detrending line 2, with the sole exception of those for HWM set E. Whereas set $\mathrm{E}$ is represented by a single peak in maximum HWM occurrence in the -2.2- to -1.0 -elevation range on the right bank, set $\mathrm{E}$ is represented by a double peak ( -2.8 to -1.7 and -1.7 to -1.0$)$ on the left bank. This double peak in maximum HWM occurrence for set E on the left bank likely arises from the complicated left-bank ledge geometry that is absent on the right bank.

\section{D-Model Best-Fit Streamflow}

The best-fit streamflows among the seven HWM sets calculated by using SToRM typically agreed with those calculated by using FaSTMECH within 13 percent if the roughness coefficients were held constant at their calibrated values (table 5). The only exceptions to this result were the model runs for HWM set B and the model runs for HWM set $\mathrm{C}$ that used 2017 bathymetry. These pairs of model runs differed by 33 and 41 percent, respectively. As described in the "Methods" section, the pre-aggradation 1926 bathymetry was used to simulate the larger floods that likely produced the HWM sets deposited before the 1970s (sets D-G), whereas the post-aggradation 2017 bathymetry was used to simulate the floods that likely produced the HWM sets deposited since the 1970s (sets A-B). Note that both the 1926 and 2017 bathymetries were used to simulate the flood(s) that produced HWM set $\mathrm{C}$ because of the less certain date of these flood(s). The physical assumptions and the calculations used within SToRM are very different than those within FaSTMECH. This 
Table 5. Best-fit streamflows for each high-water-mark set.

[HWM, high-water mark; $\mathrm{m}^{3} / \mathrm{s}$, cubic meter per second; $n$, Manning's roughness coefficient; $\%$, percent]

\begin{tabular}{|c|c|c|c|c|}
\hline \multirow{2}{*}{$\begin{array}{l}\text { HWM } \\
\text { set }\end{array}$} & \multirow{2}{*}{$\begin{array}{l}\text { Year of bathymetry } \\
\text { used in model grid }\end{array}$} & \multicolumn{2}{|c|}{ Best-fit streamflow $\left(\mathrm{m}^{3} / \mathrm{s}\right)$} & \multirow{2}{*}{$\begin{array}{l}\text { Difference in SToRM best-fit streamflow } \\
\text { relative to FaSTMECH streamflow (\%) }\end{array}$} \\
\hline & & FaSTMECH $n=0.035$ & SToRM $n=0.028$ & \\
\hline A & 2017 & 325 & 312 & -4 \\
\hline B & 2017 & 525 & 700 & +33 \\
\hline $\mathrm{C}$ & 2017 & 675 & 950 & +41 \\
\hline $\mathrm{C}$ & 1926 & 1,200 & 1,250 & +4 \\
\hline $\mathrm{D}$ & 1926 & 1,500 & 1,700 & +13 \\
\hline $\mathrm{E}$ & 1926 & 2,400 & 2,450 & +2 \\
\hline $\mathrm{F}$ & 1926 & 3,400 & 3,400 & 0 \\
\hline G & 1926 & 5,500 & 5,000 & -9 \\
\hline
\end{tabular}

result implies that the model-predicted best-fit streamflows are reasonably accurate with respect to the actual streamflows that produced HWM sets A through $\mathrm{C}$ and especially accurate for the larger floods that produced sets D through $\mathrm{G}$ (where the mean disagreement between models equaled only 6 percent).

\section{D-Model Sensitivity}

The 2D models used in our study are relatively insensitive to changes in roughness but highly sensitive to changes in topography. To evaluate each model's sensitivity to changes in roughness, we varied Manning's $n$ values around the calibrated values of 0.035 for FaSTMECH and 0.028 for SToRM. FaSTMECH models were run by use of the equivalent $c_{\mathrm{d}}$ associated with Manning's $n$ values of $0.025,0.035$ (the calibrated value), and 0.045. In FaSTMECH, a 0.01 increase in Manning's $n$ resulted in a mean decrease of 5 percent in best-fit streamflow among the seven HWM sets, whereas a 0.01 decrease in Manning's $n$ resulted in a mean increase of 11 percent in best-fit streamflow. SToRM models were run at Manning's $n$ values of $0.025,0.028$ (the calibrated value), 0.03 , and 0.04. In SToRM, a 0.01 increase in Manning's $n$ resulted in a mean decrease in best-fit streamflow of 3 percent among the seven HWM sets, whereas a 0.005 decrease in Manning's $n$ resulted in a mean increase in best-fit streamflow of 6 percent.

To evaluate model sensitivity to topography, we ran the calibrated SToRM model (where $n=0.028$ ) for HWM sets C, D, E, F, and G by using both the 2017 and 1926 bathymetry and found best-fit streamflows for each. Use of the postaggradation 2017 bathymetry instead of the deeper 1926 bathymetry resulted in decreases in the model-predicted bestfit streamflows ranging from 6 percent for the highest best-fit streamflow (HWM set G) to 28 percent for the lowest (HWM set C).

\section{Discussion}

We compared the results of simulated peak flows from HWMs to the peak flows recorded by streamgages. We also assessed the changes in the longitudinal water-surface profile of the lower Little Colorado River and the possible mechanisms by which these changes have occurred. This section of the report includes discussions of the peak-flow comparison, geomorphic changes, and possible implications for fish habitat.

\section{Peak-Flow History of the Lower Little Colorado River}

Our methods for identifying distinct HWM sets detected several historical floods similar to the number of preservable peak flows determined from the gaging records. Despite the ledge-geometry complications associated with HWM set E, the (1) identical elevation ranges of each HWM set between the left and right banks, and the (2) mostly identical elevations of maximum HWM occurrences within each HWM set between the left and right banks strongly indicate that our binning and segregation process detected the correct number of preserved HWM sets. The seven detected HWM sets (A through G) record the occurrence of seven historical floods with progressively declining peak stage, whereas analyses of the gaging and historical records indicate the occurrence of nine preservable peak flows since 1923 and the likelihood of older larger flood(s). As described below, 20th century aggradation of the bed of the Little Colorado River in the model reach likely caused several of the strandlines from the peak flows to be preserved as amalgamated strandlines within a single HWM set. Thus, it is highly likely that 10 peak flows could have been preserved as seven distinct HWM sets. 
The results from numerical modeling of the surveyed HWM sets compare favorably with the reconstructed history of preservable peak flows on the lower Little Colorado River (fig. 12). Agreement is better between the best-fit FaSTMECH streamflows and the peak flows of the preservable peak flows determined from the gaging records than it is between the best-fit SToRM streamflows and the peak flows of the preservable peak flows. Thus, for simplicity, we use only the FaSTMECH-simulated streamflows in the discussion herein. It is not surprising that the two lowest elevation HWM sets emplaced by relatively recent floods have the best agreement between model predictions and measurements. That the best-fit simulated streamflow for the lowest set A is $325 \mathrm{~m}^{3} / \mathrm{s}$ indicates that HWM set A was deposited by the September 11, 2002 , flood with a peak flow of $326 \mathrm{~m}^{3} / \mathrm{s}$ at the near-Cameron streamgage. That the best-fit simulated streamflow for set B, the next highest set, is $525 \mathrm{~m}^{3} / \mathrm{s}$ indicates that HWM set B was mostly deposited by the January 12, 1993, flood with a peak flow of $515 \mathrm{~m}^{3} / \mathrm{s}$ at the near-Cameron streamgage. Set B may also include some driftwood from a slightly smaller $459 \mathrm{~m}^{3} / \mathrm{s}$ peak flow on February 23, 1993.
The higher elevation, and therefore older, HWM set $\mathrm{C}$ was likely deposited during a period of travertine-dam aggradation (as described below) and therefore may include an amalgamation of driftwood from older floods with larger peak flows and younger floods with lower peak flows. We therefore ran models with both the aggraded 2017 bathymetry and the incised 1926 bathymetry for this HWM set. For the 2017 bathymetry, the best-fit simulated streamflow of $675 \mathrm{~m}^{3} / \mathrm{s}$ agrees well with the reported $634-\mathrm{m}^{3} / \mathrm{s}$ peak flow of the October 19, 1972, flood at the near-Cameron streamgage. For the 1926 bathymetry, the best-fit simulated streamflow of $1,200 \mathrm{~m}^{3} / \mathrm{s}$ agrees well with the reported $1,080-\mathrm{m}^{3} / \mathrm{s}$ peak flow of the March 5, 1938, flood at the Grand Falls streamgage. Long profiles show that the model reach aggraded 1 to $4 \mathrm{~m}$ from 1926 to 1992. Photographs and observations from the 1950s show base-flow water-surface elevations similar to those in the 1926 profile, whereas a photograph from the early 1970s at Rkm 1.2 shows the base-flow water surface only about $0.5 \mathrm{~m}$ lower than in 1992. Therefore, the aggradation in the model reach occurred between the 1950s and 1992, with only $0.5 \mathrm{~m}$ of the 1 - to $4-\mathrm{m}$ aggradation occurring after

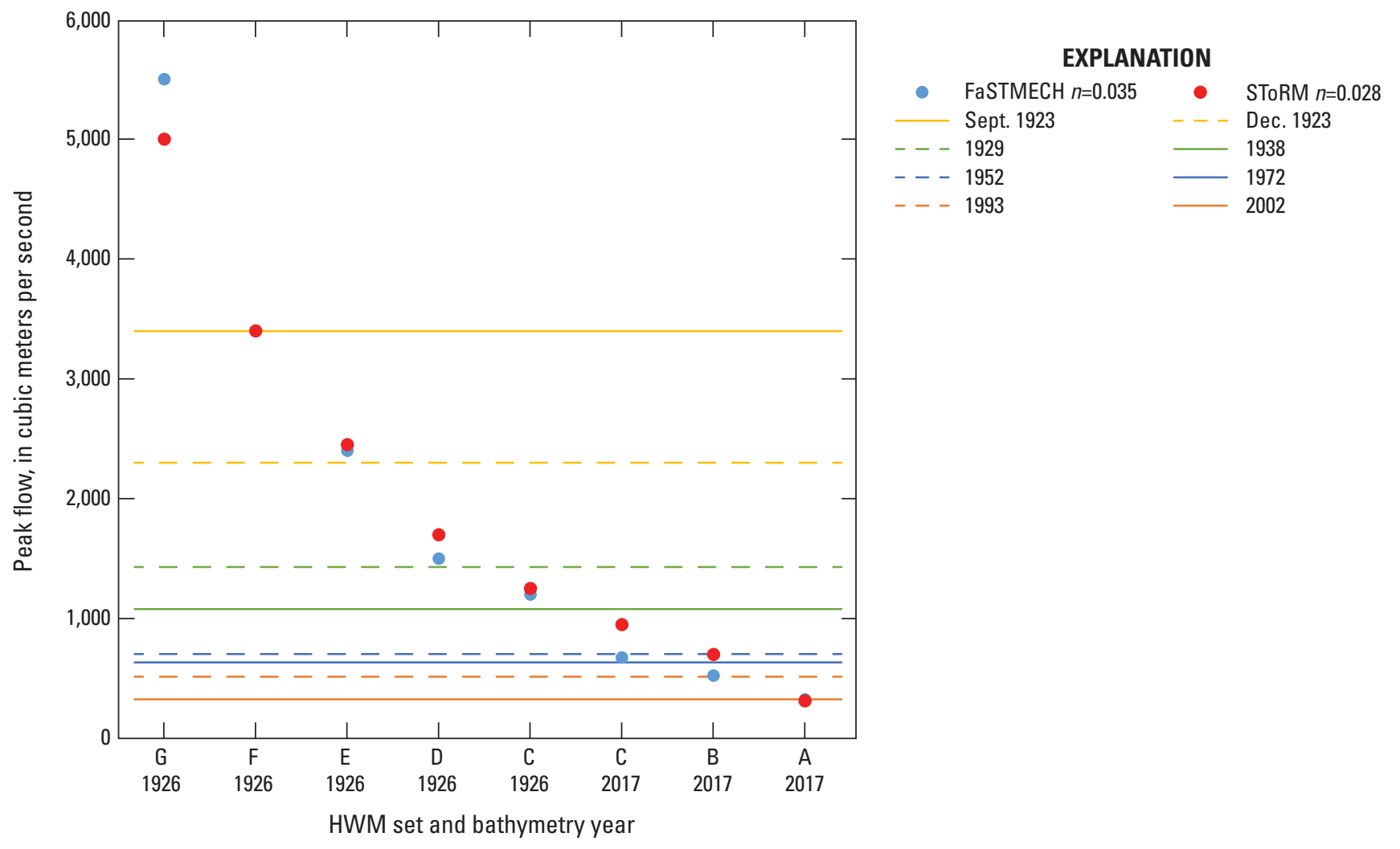

Figure 12. Plot showing the best-fit FaSTMECH- and SToRM-predicted streamflows for the seven high-watermark (HWM) sets compared with the peak flows associated with the preservable peak flows reconstructed from the gaging records. The best-fit streamflows predicted by FaSTMECH and SToRM are indicated by the circles. The peak flows of the gaged historical floods associated with the preservable peak flows are shown as horizontal lines. The elevations of the channel bed were much lower in the 1926 bathymetry than in the 2017 bathymetry, as described in the "Methods" section. $n$, Manning's roughness coefficient. 
the early 1970s. Thus, it is likely that HWM set C includes driftwood from the 1938 and 1972 floods. Any HWMs from the $705-\mathrm{m}^{3} / \mathrm{s} 1952$ flood would have been deposited before aggradation in the model reach and were therefore likely erased by the 634-m³/s 1972 flood. Despite the 1972 flood having a slightly lower peak flow than the 1952 flood, the 1972 flood likely reached a higher stage than the 1952 flood in the model reach because the 1972 flood occurred after most of the aggradation.

The higher elevation HWM sets D, E, and F were likely deposited during floods in 1923 and 1929 and were thus simulated by the use of only the 1926 bathymetry. That the best-fit simulated streamflow for HWM set D is $1,500 \mathrm{~m}^{3} / \mathrm{s}$ indicates that set $\mathrm{D}$ was deposited by the flood with a peak flow of 1,430 $\mathrm{m}^{3} / \mathrm{s}$ on April 5, 1929, at the Grand Falls streamgage. The best-fit simulated streamflow for HWM set $\mathrm{E}$ is $2,400 \mathrm{~m}^{3} / \mathrm{s}$, indicating that set $\mathrm{E}$ was deposited by the December 28,1923 , flood with a peak flow of $2,300 \mathrm{~m}^{3} / \mathrm{s}$ estimated from the Wiele and Smith (1996) and Wiele and Griffin (1997) streamflow-routing model. The best-fit simulated streamflow of $3,400 \mathrm{~m}^{3} / \mathrm{s}$ for HWM set F agrees perfectly with the $3,400 \mathrm{~m}^{3} / \mathrm{s}$ peak flow of the flood observed at Cameron, Ariz., on September 19, 1923, that was estimated by applying a rating-curve extrapolation to the data collected at the Grand Falls streamgage.

In addition to the eight gaged floods that most likely deposited the driftwood in HWM sets A through F, we detected an additional ungaged flood evidenced by the highest HWM set preserved in the reach - set G. Depending on whether the results from FaSTMECH or SToRM are used, the best-fit simulated streamflow for HWM set G range from 5,000 to $5,500 \mathrm{~m}^{3} / \mathrm{s}$. The uncertainty in the best-fit simulated streamflow for this set is much higher than for the other HWMs because this set consists of only five driftwood logs. The only known historical flood that was likely much larger than the September 1923 flood was the "super-flood" of early 1888 documented and named as such by Bell (1937). Thus, it is possible that HWM set $\mathrm{G}$ was deposited by this super-flood.

A peak flow of 5,000 to $5,500 \mathrm{~m}^{3} / \mathrm{s}$ for Bell's 1888 superflood is consistent both with 1890 photographic evidence from locations downstream in the Colorado River and with post-1888 Colorado-River-flood history. The 1888 superflood was preceded by the Colorado River flood of 1884, which had a peak flow of $5,500 \mathrm{~m}^{3} / \mathrm{s}$ (Topping and others, 2003), and was followed by the Colorado River flood of 1921 , which had a peak flow of $4,800 \mathrm{~m}^{3} / \mathrm{s}$. No floods larger than the 1921 flood had occurred in the Colorado River at the Lees Ferry streamgage between 1884 and 1921. Additionally, no evidence of any late 19th or early 20th century floods larger than the 1921 flood was found at the Grand Canyon streamgage except for an HWM consistent with the peak flow of the 1884 flood (Topping and others, 2003). Large floods from the Little Colorado River have been observed to attenuate in the Colorado River by about 14 to 37 percent, so a 5,000 to $5,500 \mathrm{~m}^{3} / \mathrm{s}$ flood emerging from the Little Colorado River would likely create a peak flow of much less than 4,300 to
$4,700 \mathrm{~m}^{3} / \mathrm{s}$ in the Colorado River downstream from the Grand Canyon streamgage. Photographs taken along the Colorado River downstream from the Little Colorado River by Robert Brewster Stanton during his 1890 expedition show evidence of 1884 flood deposits reworked by a slightly lower flood (U.S. Geological Survey, 2018). This slightly lower flood therefore must have occurred between 1884 and 1890. All evidence of this likely 4,300- to $4,700-\mathrm{m}^{3} / \mathrm{s}$ flood would have been erased by the larger $4,800-\mathrm{m}^{3} / \mathrm{s} 1921$ flood. Thus, evidence of only the 1921 and 1884 floods would be preserved along the modern Colorado River (Draut and others, 2005), with no preservation of HWMs from the 1888 Little Colorado River super-flood.

\section{Backwater Effects from Colorado River Floods}

Backwater effects from Colorado River floods were evaluated for each HWM set to ensure that the HWMs used for peak-flow modeling were deposited during Little Colorado River floods rather than during Colorado River floods. We compared the elevation of the lowest HWM in each set with the likely maximum stage at the confluence during all post1884 Colorado River floods. The values of peak-flood stage at the confluence were based on measurements at the Coloradoabove-LCR streamgage for time periods when this streamgage was active. When the Colorado-above-LCR streamgage was not active, the peak stage at the confluence was estimated on the basis of the peak flow at the Lees Ferry streamgage and the 1985 stage-discharge relation at the Colorado-aboveLCR streamgage. For flows much higher than the measured $2,750-\mathrm{m}^{3} / \mathrm{s}$ peak flow of the 1983 Colorado River flood at the Lees Ferry streamgage (included in the 1985 stage-discharge relation at the Colorado-above-LCR streamgage), peak stage at the confluence was estimated by using the water-surface profiles simulated by Magirl and others (2008) and strandline surveys of historical floods in the Colorado River (Sabol and others, 2021).

As in the Little Colorado River, peak-flow magnitude has also declined in the Colorado River over the study period (Topping and others, 2003). Consequently, the elevation and headward extent of backwater in the lower Little Colorado River during Colorado River floods has declined over time. Thus, because Colorado River backwater could affect only those HWMs already deposited along the Little Colorado River at the time of Colorado River backwatering, it is important to understand the interaction of the peak-flow histories of the Colorado and Little Colorado Rivers. Specifically, it is important to understand the sequence of peak stages in both rivers and the elevations of these stages in the Rkm-0.5-to- 1.5 model reach in the Little Colorado River.

The historical flood of record on the Colorado River at the locations of both the Lees Ferry and Grand Canyon streamgages occurred before the establishment of these streamgages in July 1884 with an estimated peak flow of $5,950 \mathrm{~m}^{3} / \mathrm{s}$. The second largest flood documented at these streamgages, which occurred in May 1921 after the establishment of the Lees Ferry streamgage, had a peak flow of $4,830 \mathrm{~m}^{3} / \mathrm{s}$ (Topping and 
others, 2003). Based on the model of Magirl and others (2008), the peak stage at the confluence of the Colorado and Little Colorado Rivers during the 1884 flood was $842.3 \mathrm{~m}$. Based on the same model and corroborated by strandline surveys of all post-1884 historical floods in the Colorado River (Sabol and others, 2021), the peak stage at the confluence during the 1921 flood was $839.2 \mathrm{~m}$ (model) or $839.1 \mathrm{~m}$ (strandline). The largest gaged flood in the Colorado River after 1921 occurred in 1927 and had a peak flow of $3,600 \mathrm{~m}^{3} / \mathrm{s}$, corresponding to a stage at the confluence of $838.1 \mathrm{~m}$. Floods of similar peak magnitude occurred five times in the Colorado River between 1927 and 1957. Since 1957, only two floods have occurred in the Colorado River that would have pushed backwater into the Little Colorado River model reach. The larger of these two floods occurred in 1958, with a peak flow of $3,000 \mathrm{~m}^{3} / \mathrm{s}$ and a peak confluence stage of about $837.5 \mathrm{~m}$ on the basis of strandline surveys of historical Colorado River floods; the smaller of these two floods occurred in 1983, with a peak flow of $2,750 \mathrm{~m}^{3} / \mathrm{s}$ and a peak confluence stage of about $836.5 \mathrm{~m}$.

It is extremely unlikely that Colorado River backwater has affected the HWM sets in any way that would have altered the best-fit simulated streamflow of Little Colorado River floods. Only the lowest one to three individual HWMs in sets C, D, E, and G could have been affected by Colorado River backwater. Furthermore, the HWM sets in the model reach were most likely deposited during Little Colorado River floods with peak stages that reached higher elevations than any of the Colorado River backwatering events that post-dated these floods. The youngest sets, HWM sets A and B, were likely deposited in 2002 and 1993, respectively, and include HWMs as low as $835.6 \mathrm{~m}$ that would have been affected by Colorado River backwater only as recently as 1983 . The next youngest set, C, was likely deposited between 1938 and 1972 and includes three HWMs as low as $837.2 \mathrm{~m}$ that could have been affected by Colorado River backwater only as recently as 1957 . The rest of the 23 HWMs in set C were higher than the elevation of the 1957 backwater and could have been affected only as recently as 1921. HWM sets D and E were likely deposited in 1929 and 1923, respectively, and include three HWMs as low as $837.6 \mathrm{~m}$ that could have been affected by 1927-1957 Colorado River floods, but the rest of the 49 HWMs would have been affected by backwater during only the 1884 and 1921 Colorado River floods. Although the lowest elevation HWMs in sets F and G are respectively within $1 \mathrm{~m}$ of the estimated peak stages of backwater during the 1921 and 1884 Colorado River floods, many of the HWMs in these sets are at higher elevations. In addition, HWM set F was most likely deposited in 1923, after the 1921 Colorado River flood, and HWM set G was likely deposited in 1888 , after the 1884 Colorado River flood. The only HWM among these sets that, with greater uncertainty, and could possibly have been deposited during Colorado River backwater is the downstream-most HWM in set G (fig. 8); the elevation of this HWM is $843.1 \mathrm{~m}$, whereas the estimated elevation of the peak stage of the backwater during the 1884 Colorado River flood is $842.3 \mathrm{~m}$. Despite this possibility, any effect of Colorado River backwater on the HWM sets can generally be ruled out because all sets slope downstream in the model reach; this orientation indicates that these HWM sets were deposited during Little Colorado River floods and not by Colorado River backwater.

\section{Changes in the Longitudinal Profile of the Lower Little Colorado River}

We used multiple datasets collected between 1909 and 2017 to assess changes in the longitudinal profile of the lower Little Colorado River (figs. 7 and 13). These datasets include base-flow longitudinal profiles from 1926, 1992, 2002, 2013, a partial profile from 2017, backwater observations from the 1950s, aerial photographs from 1933-1934 and 1951-1958, and repeated photographs of locations in 1909, 1911, 1932, 1948-1950s, and the early 1970s. As described in the "Results" section, the major differences between the 1992, 2002, and 2013 longitudinal profiles occurred only near Chute falls at Rkm 14.2 and near Blue Spring at Rkm 20.8. There were no detected differences between the 2013 profile and the 2017 partial profile. Based on our field visits and observations, between 2017 and 2019, there were no obvious debris-flow inputs or major incidents of travertine-dam collapse, with the exception of the above-mentioned partial collapse of Chute falls in 2016-2017 documented by Dennis Stone of the USFWS. We therefore assumed a similar longitudinal profile between 2013 and 2019 to compare elevations of the water surface determined from repeat photography in 2013 and 2019 with the base-flow water-surface elevations in the complete longitudinal profiles from 2002 and 2013.

In general, the upstream half of our study area has undergone mostly incision (Rkm 9 through 22), whereas the downstream half of our study area ( $\mathrm{Rkm} 0$ through 9 ) has undergone mostly aggradation since the early to middle 20th century (fig. 13). During the earliest part of the 20th century (post-1909 to pre-1952), when larger floods were more common in the Little Colorado River, large amounts of both incision and aggradation were detected upstream from about

Figure 13 (page 25). Plots of changes in the base-flow longitudinal profile and water-surface elevations for the lower Little Colorado River. $A$, Changes in the base-flow longitudinal profile of the lower Little Colorado River relative to 2013. The height of boxes marking data points indicates the approximate vertical uncertainty in meters of elevation. The length of boxes marking data points indicate the approximate horizontal uncertainty in river kilometers $(\mathrm{R} k \mathrm{~km})$. Positive values of change indicate aggradation, and negative values of change indicate incision. $B$, Time series of elevation relative to the elevation in 2013 of the base-flow water-surface elevation at the locations of repeated photographs, backwater observations, and mid-channel rocks indicating only minimal post-1951 change between Rkm 0 and 9. Negative values indicate elevations that were lower in the specified year than the elevation in 2013. C, Time series of elevation relative to the elevation in 2013 of the base-flow water-surface elevation at the locations of repeated photographs and locations of mid-channel rocks indicating only minimal post- 1951 change between Rkms 9 and 22. Positive values indicate elevations that were higher in the specified year than the elevation in 2013. 

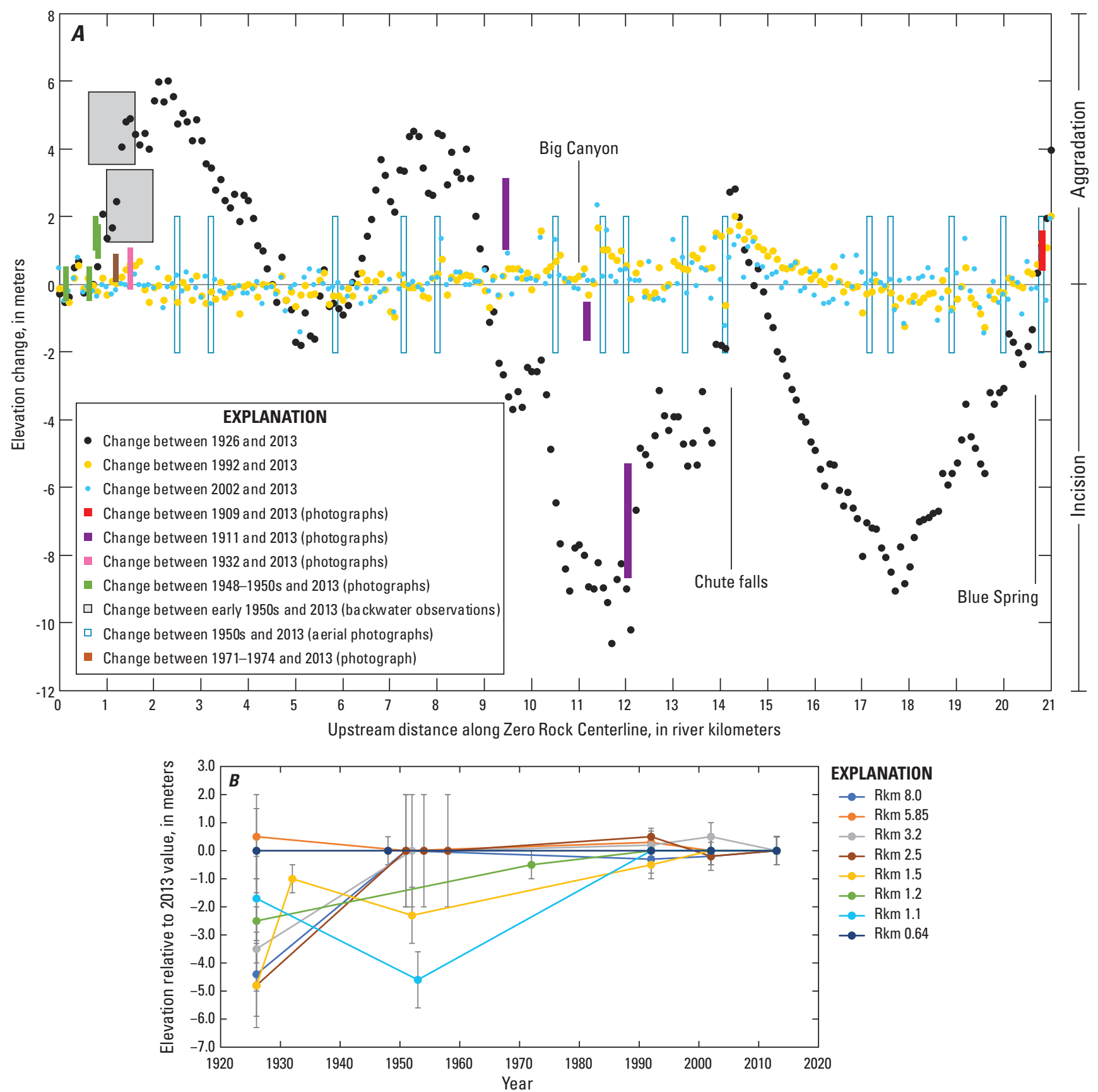

EXPLANATION

$\rightarrow$ Rkm 8.0

$\longrightarrow$ Rkm 5.85

- Rkm 3.2

$\rightarrow$ Rkm 2.5

Rkm 1.5

$\longrightarrow$ Rkm 1.2

$\Longrightarrow$ Rkm 1.1

$\rightarrow$ Rkm 0.64

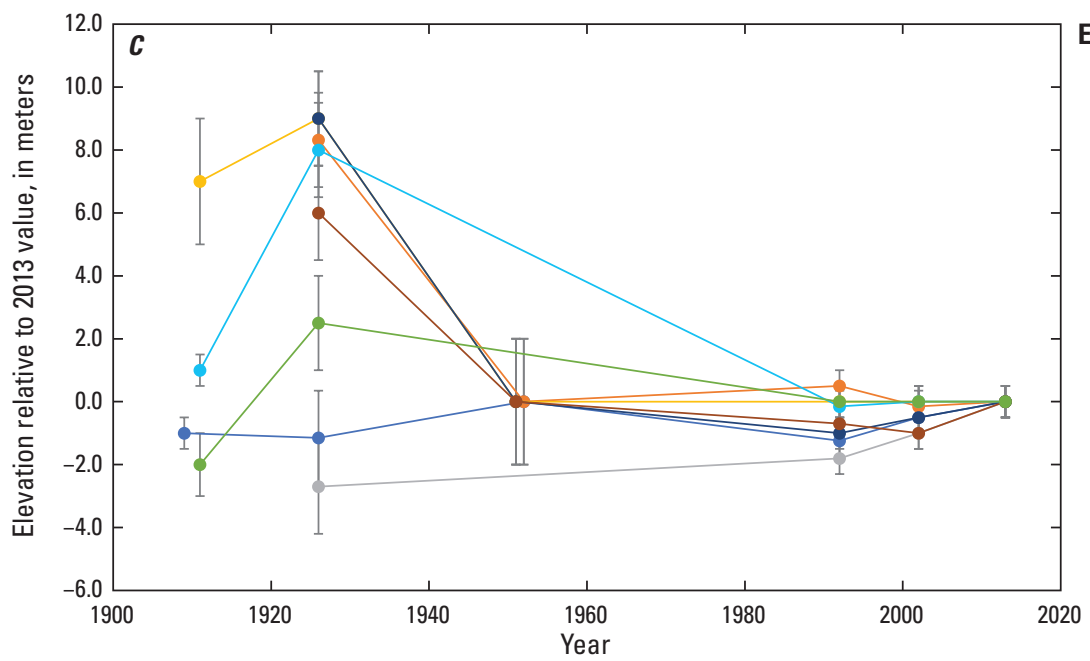

EXPLANATION

$\rightarrow$ Rkm 20.8

$\multimap$ Rkm 17.6

$\rightarrow$ Rkm 14.2

$\rightarrow$ Rkm 12.05

$\longrightarrow$ Rkm 11.5

$\rightarrow$ Rkm 11.15

$\longrightarrow$ Rkm 10.5

$\longrightarrow$ Rkm 9.45 
$\mathrm{Rkm}$ 1. This result indicates that both the growth and collapse of travertine dams occurred at a higher rate, and that the river was therefore much more dynamic during the presence of the multiple floods with peak flows greater than $1,080 \mathrm{~m}^{3} / \mathrm{s}$ that occurred through 1932 and floods with peak flows greater than $400 \mathrm{~m}^{3} / \mathrm{s}$ that were common through 1952 . Since the early 1950 s, aggradation has dominated in all parts of our study area where we have data. Since 1992, the longitudinal profile of the lower Little Colorado River has remained relatively stable between $\mathrm{Rkm} 0$ and 22, except for two isolated areas near Rkms 14 and 21 where larger amounts of aggradation have occurred. This general stability with isolated large amounts of aggradation occurred during an era without large floods. Since 1993, only one flood with a peak flow larger than $213 \mathrm{~m}^{3} / \mathrm{s}$ has occurred-the $326-\mathrm{m}^{3} / \mathrm{s}$ flood in 2002 . These results indicate that without larger floods, travertine dams mostly grow until they simply become unstable and collapse (as at Chute falls in 2016-2017). The longitudinal profile of the lower Little Colorado River therefore only remains stable or aggrades in the absence of large floods.

\section{Rkm 0 to 9}

The reach from the confluence at $\mathrm{Rkm} 0$ to $\mathrm{Rkm} 9$ has aggraded substantially since 1926 . This observed aggradation occurred mostly between 1926 and the 1950s and to a lesser degree between the early 1950 s and 1992 . The reach has remained essentially unchanged between 1992 and 2017 (fig. 13). The elevation of the confluence of the Colorado and
Little Colorado Rivers has been relatively stable since at least 1926, and is within $\pm 1 \mathrm{~m}$ among all base-flow longitudinal profiles from 1926 to 2013; however, major changes in the base-flow water-surface elevation have occurred since 1926 just upstream from the confluence. The base-flow watersurface profile from $\mathrm{Rkm} 0$ to 5 was 2-6 m higher and more irregular from 1992 to 2013 than in 1926. Between Rkm 0 and 1, the profile changed little between 1926 and the 1950s, and only 0 to $1 \mathrm{~m}$ of aggradation occurred between the 1950s and 1992. At Rkm 0.78, a 1950s photograph shows the base-flow water surface about $1.5 \mathrm{~m}$ lower than in 2019 (fig. 14). In contrast, the reach near Rkm 1 to 1.5 aggraded substantially between 1926 and 1932 then continued at a slower pace through 1992. A 1932 photograph taken at Rkm 1.5 shows the base-flow water surface around $1 \mathrm{~m}$ lower than in 2019 (fig. 15). At Rkm 1.5, 4 m of aggradation occurred between 1926 and 1932. Additional aggradation occurred in this short reach after 1932 — about 0.5 to $1 \mathrm{~m}$ between 1952 and the early $1970 \mathrm{~s}$, and about $0.5 \mathrm{~m}$ between the early $1970 \mathrm{~s}$ and 1992.

Farther upstream, from Rkm 2 to 9, most of the aggradation occurred between 1926 and 1951. From Rkm 2 to 4, the profile aggraded 2 to $6 \mathrm{~m}$ between 1926 and 1992. Aerial photographs of Rkms 2.5 and 3.2 indicate that most of this aggradation occurred prior to 1951. Between Rkms 4.5 and 6.3, the base-flow longitudinal profile of the river has not measurably changed since 1926 . There is a minor tributary on the right bank near Rkm 5 and an associated 4-m-high travertine-dam complex. Upstream from this section of stability, substantial
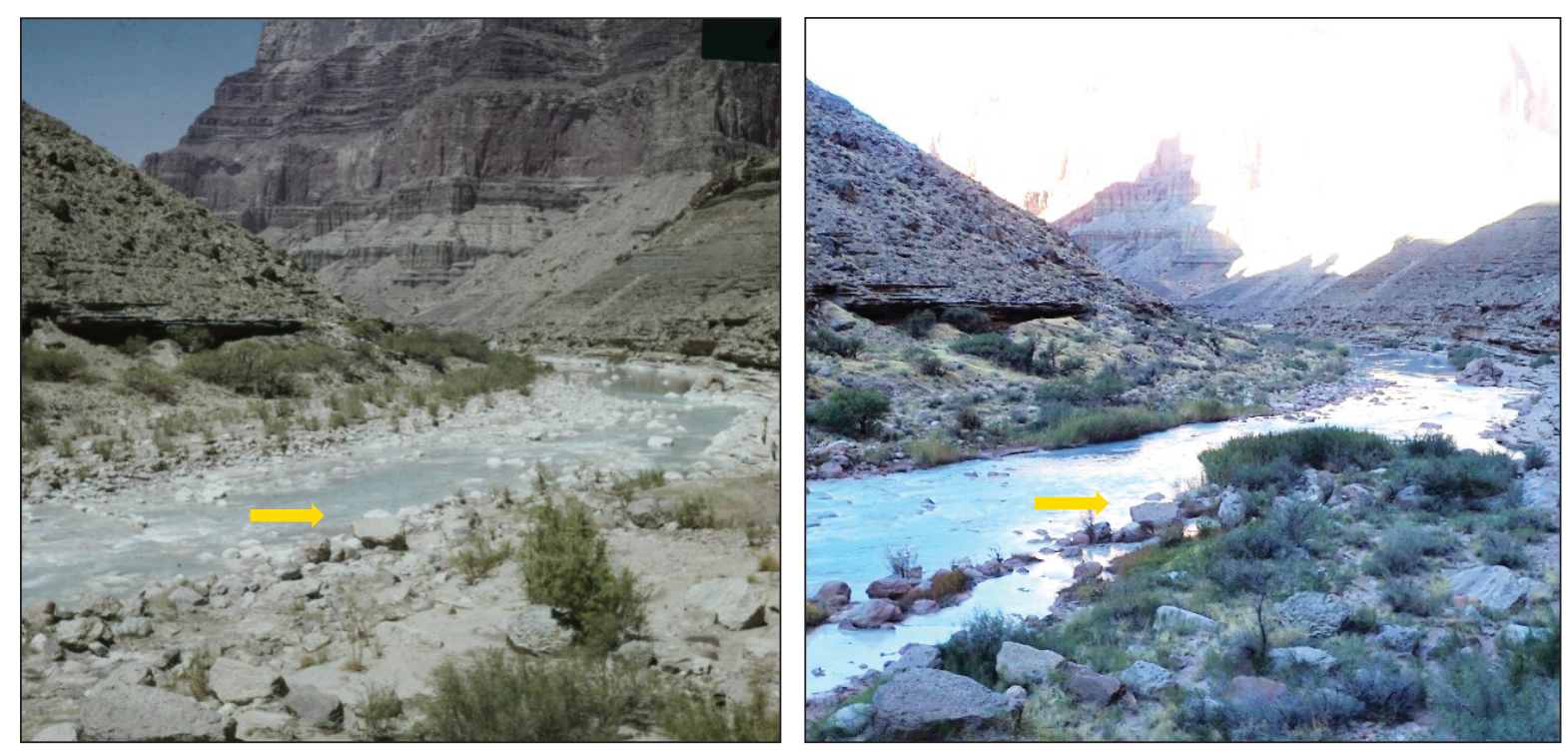

Figure 14. Repeated photographs from the 1950s and 2019 of the Little Colorado River at river kilometer (Rkm) 0.78 ; view is upstream. The 1950s photograph (left) is part of the Katie Lee collection and is matched in the 2019 photograph by Joel Unema (right). Arrows mark the top of the same rock in both photographs. Hand-level measurements in 2019 show that the base-flow water surface was $1.5 \pm 0.5$ meters $(\mathrm{m})$ higher in 2019 than in the 1950 s, indicating approximately $1.5 \mathrm{~m}$ of bed aggradation and (or) travertine-dam growth near Rkm 0.78 between the 1950s and 2019. 

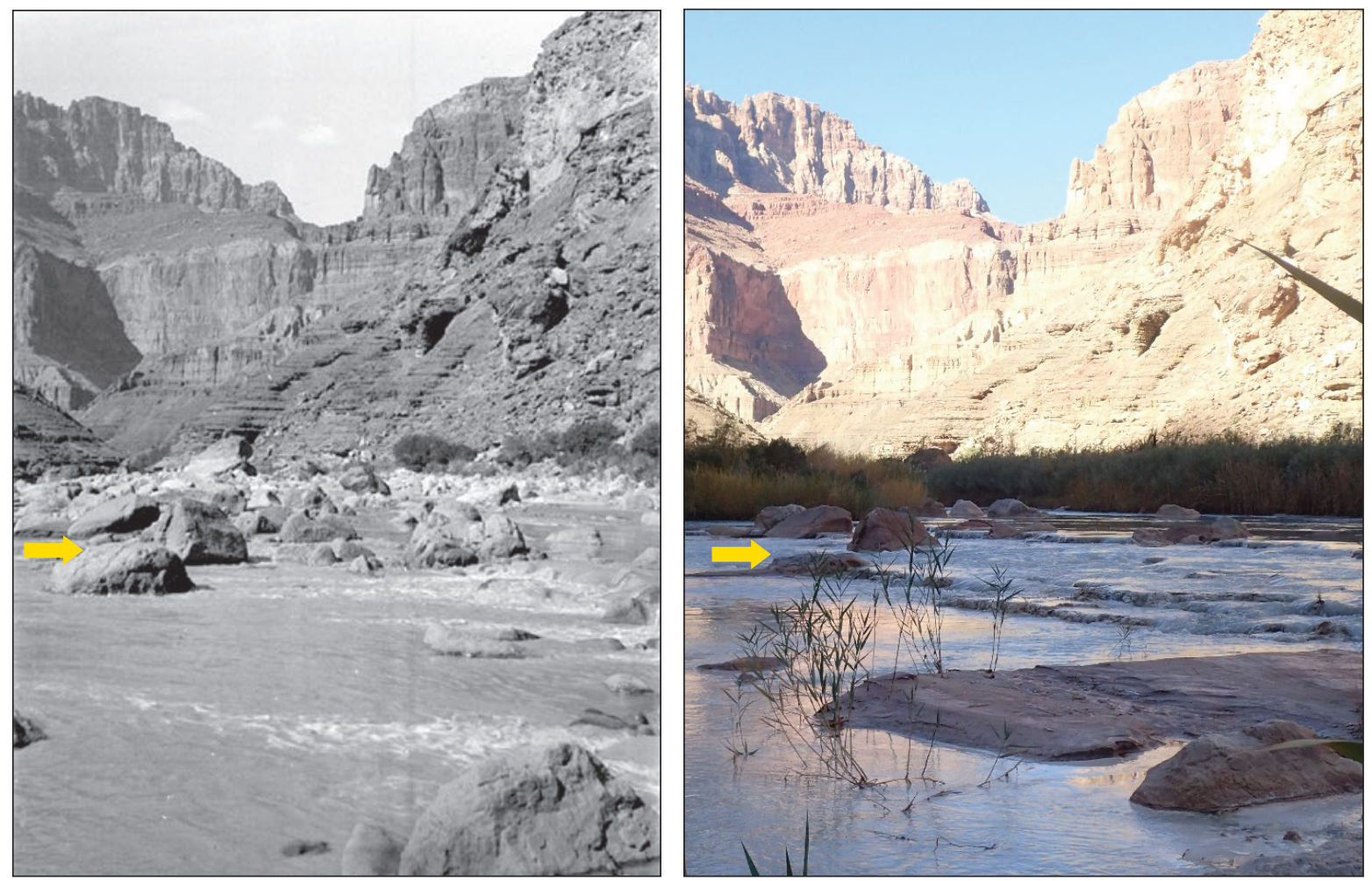

Figure 15. Repeated photographs from 1932 and 2019 of the Little Colorado River at river kilometer (Rkm) 1.5; view is downstream. The 1932 photograph was taken by Barbara and Edwin McKee (left) and is matched in the 2019 photograph by Joel Unema (right). Arrows mark the top of the same rock in both photographs. Hand-level measurements in 2019 show that the base-flow water surface was $1.0 \pm 0.5$ meter $(\mathrm{m})$ higher in 2019 than in 1932, indicating approximately $1 \mathrm{~m}$ of travertine-dam aggradation at Rkm 1.5 between 1932 and 2019 .

aggradation occurred between 1926 and 1951. From Rkm 5 to 9, the 1992-2013 profiles are approximately 2 to $6 \mathrm{~m}$ higher than the 1926 profile. Mid-channel rocks in aerial photographs at Rkms 5.8, 7.3, and 8.0 indicate that most of the reach between Rkms 5 and 9 aggraded to near-1992 elevations by the early 1950s. This reach is a step-pool system with no tributaries and numerous small travertine dams.

\section{Rkm 9 to 22}

Similar to changes in the reach between Rkms 2 and 9, much of the change in the profile between Rkms 9 and 22 occurred between 1926 and the early 1950s. Most of the reach from $\mathrm{Rkm} 9$ to 22 has incised since 1926, with only two isolated areas currently undergoing large amounts of aggradation (near Chute falls and Blue Spring). Before 1926, more extensive parts of this reach were aggraded. Aerial photographs throughout this reach show that many areas were incised to near-1992 elevations between 1926 and the early 1950s. Specifically, mid-channel rocks in aerial photographs indicate that the base-flow water-surface elevation has not measurably changed since 1951 at Rkms 10.5, 11.5, 12.0,
13.2, 14.1, 17.1, 17.6, 18.9, and 20.0. The largest and most extensive amount of historical aggradation occurred between Rkm 9 and 11.5; this reach aggraded between 1911 and 1926 before incising between 1926 and 2002 (fig. 7). At Rkm 9.45, a 1911 photograph shows a water-surface elevation about $2 \mathrm{~m}$ lower than in 2013 (fig. 16), which is, in turn, about $4 \mathrm{~m}$ lower than in 1926 (fig. 7). A 1911 photograph at Rkm 11.15, just upstream from Big Canyon, shows a water-surface elevation about $1 \mathrm{~m}$ higher than in 2013 (fig. 17), but about $6 \mathrm{~m}$ lower than in 1926 (fig. 13). After the rapid 1911-1926 aggradation between Rkms 9 and 11.5, the reach between Rkms 9 and 13 was incised by approximately 2 to $10 \mathrm{~m}$ between 1926 and the 1950s, and thereafter remained stable (fig. 7).

A large part of the $\mathrm{Rkm} 9$ to 13 reach became incised through the collapses of travertine dams between 1926 and the 1950s. A 1911 photograph shows a large travertine-dam complex at Rkm 12.05 (fig. 18). In 1926, this dam was still likely intact, as indicated by the similar base-flow watersurface elevations at Rkm 12.05 in 1911 and 1926. Sometime between 1926 and 1951, this dam was breached, and the reach between Rkms 9 and 13.8 became incised; as a result, only bank-side remnants of this travertine dam persisted in our 

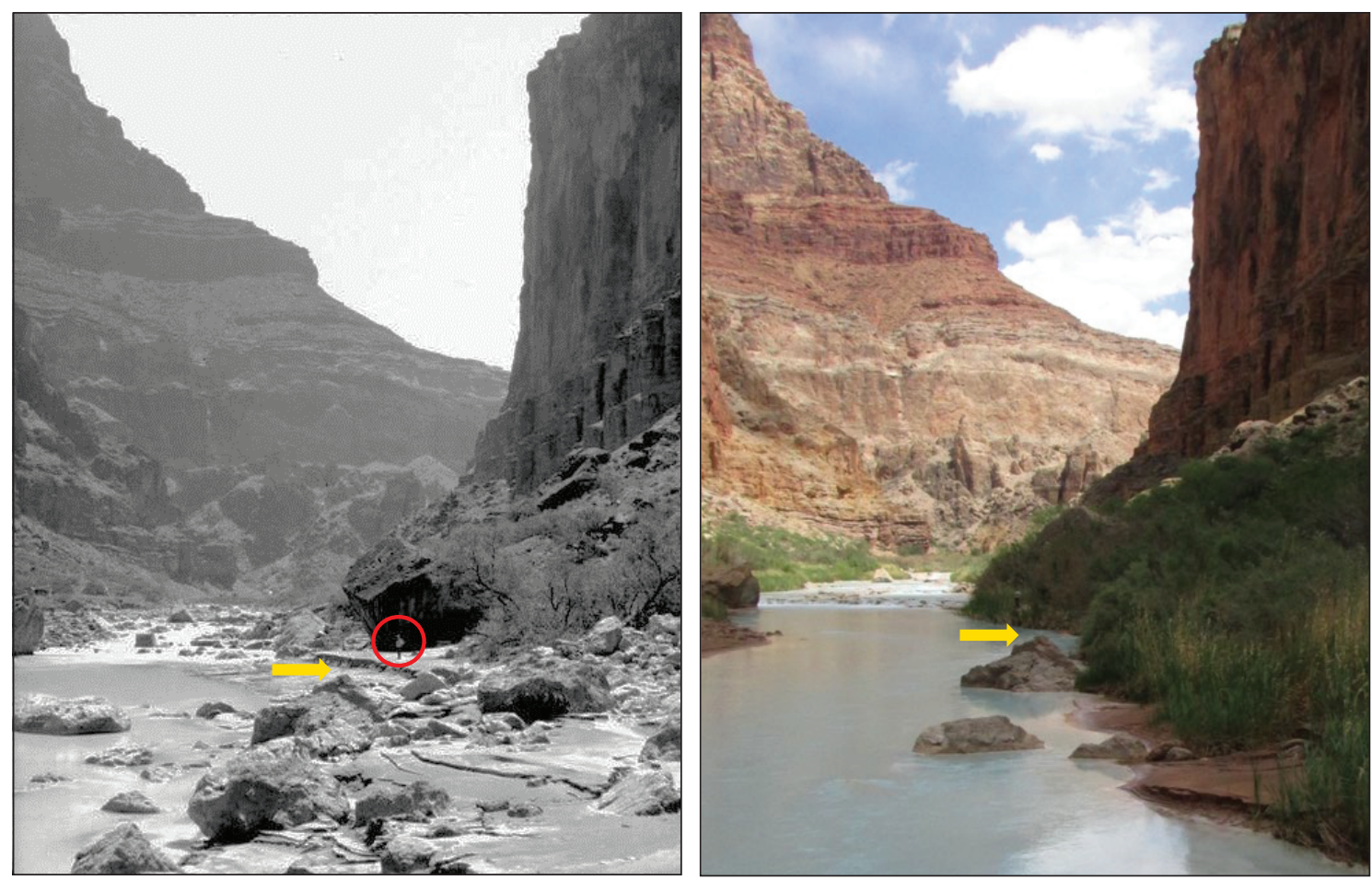

Figure 16. Repeated photographs from 1911 and 2013 of the Little Colorado River below Salt Trail Canyon at river kilometer (Rkm) 9.45; view is upstream. The 1911 photograph was taken by Emery Kolb (left) and the 2013 photograph by Michael Pillow (right). Arrows mark the top of the same rock in both photographs. The base-flow water surface was estimated to be $2 \pm 1$ meters $(\mathrm{m})$ higher in 2013 than in 1911; this estimation used the person of about $1.7 \mathrm{~m}$ height (circled) for scale because this site was not measured in 2019. Thus, about 2 $\mathrm{m}$ of bed aggradation and (or) travertine-dam growth occurred near Rkm 9.45 between 1911 and 2013.
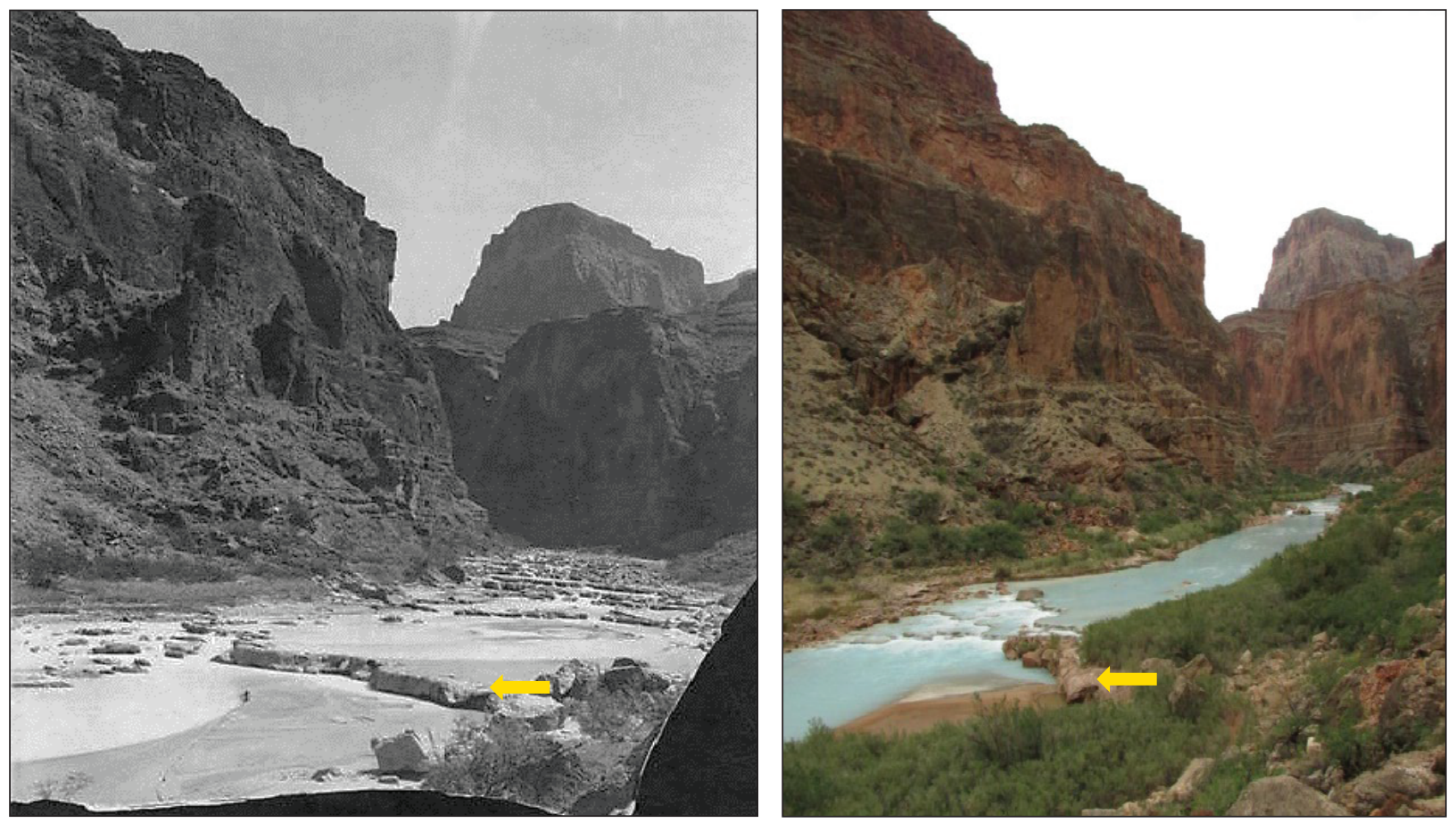

Figure 17. Repeated photographs from 1911 and 2013 of the Little Colorado River upstream from Big Canyon at river kilometer (Rkm) 11.15; view is upstream. The 1911 photograph was taken by Emery Kolb (left) and the 2013 photograph by Michael Pillow (right) was taken from a slightly different vantage point. Hand-level measurements in 2019 show that the water surface was $1.0 \pm 0.5$ meter $(\mathrm{m})$ lower in 2013 than in 1911, indicating that about $1 \mathrm{~m}$ of travertine-dam incision occurred near Rkm 11.15 between 1911 and 2013. The breached travertine dam (marked by arrows) that was active in 1911 is evident in the foreground of the 2013 photograph. 

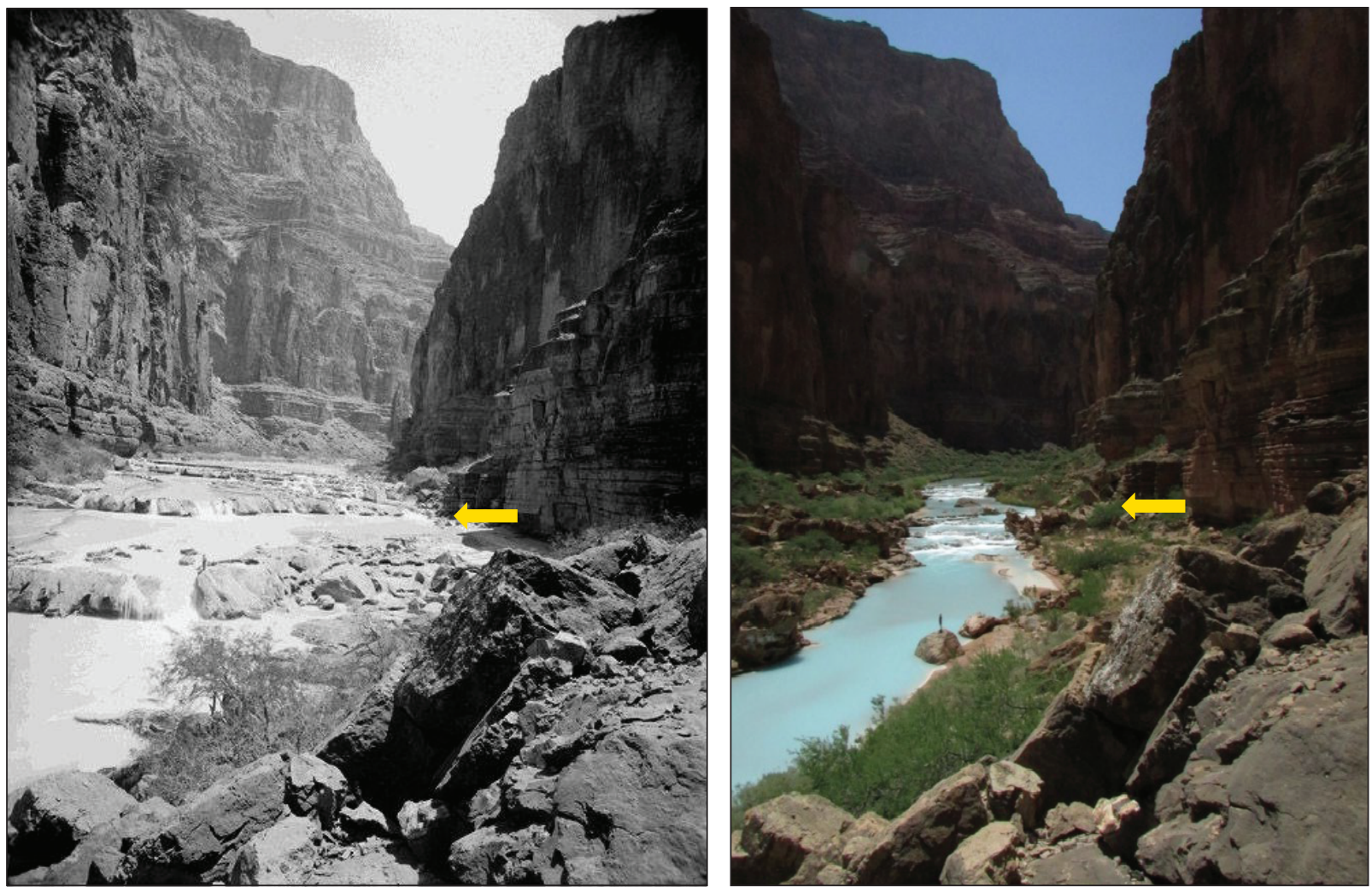

Figure 18. Repeated photographs from 1911 and 2013 of the Little Colorado River upstream from Big Canyon at river kilometer (Rkm) 12.05; view is upstream. The 1911 photograph was taken by Emery Kolb (left) and the 2013 photograph by Michael Pillow (right). Arrows mark the crest elevation of the same travertine dam in both photographs. Hand-level measurements in 2019 show that the base-flow water surface elevation was 7 \pm 2 meters $(\mathrm{m})$ lower in 2013 than in 1911, indicating that about $7 \mathrm{~m}$ of travertine-dam incision occurred near Rkm 12.05 between 1911 and 2013.

2013 counterpart of the 1911 photograph (fig. 18). We could not find any observations or photographs of this reach taken during the period 1926 through 1951, so the exact dates and rates of dam failure and channel incision remain unknown.

The reach near Chute falls has undergone relatively small changes in elevation but substantial changes in slope. At Rkm 14.2, the 2013 base-flow water-surface elevation was about $0.7 \mathrm{~m}$ higher than in 2002, about $1.5 \mathrm{~m}$ higher than in 1992, and about $2.7 \mathrm{~m}$ higher than in 1926 (fig. 7). These changes are likely caused by the growth of the travertine dams that form the falls. These falls were likely absent in 1926 because there was no abrupt slope break near Rkm 14 in the 1926 longitudinal profile. Thus, although older, higher elevation breached travertine dams are present at this location, the present-day Chute falls is a relatively new feature that has grown considerably since only 1992 and perhaps at a higher rate than between 1926 and 1992. Therefore, the physical barrier of Chute falls forms a modern impediment to the upstream migration of humpback chub. The reach just downstream from the crest of Chute falls, from
Rkm 13.8 to 14.2 , had a steep (2.4 percent) slope in both 2002 and 2013 with an 11-m drop in only the 400-m-long reach. In contrast, before the recent growth of Chute falls, the slope of this reach was only 0.7 percent in 1926.

Upstream from Chute falls, in the reach between Rkm 15 and 20, the channel was incised by about 2 to $8 \mathrm{~m}$ between 1926 and 1992. Aerial photographs from 1951 and 1952 show that some locations incised to near-1992 elevations before the early 1950s - specifically, at Rkms 17.1, 17.6, and 18.9. This is the same type of response observed downstream from Chute falls in the reach between Rkms 9 and 13.8, which also was incised between 1926 and the 1950s. Only negligible change in the longitudinal profile occurred upstream from Rkm 20 until 1992, when the profile began to aggrade. A photograph from 1909 shows a base-flow water-surface elevation at Rkm 20.8 at Blue Spring that was about $1 \mathrm{~m}$ lower than in 2013 (fig. 19). Comparison of the 1926, 1992, 2002, and 2013 longitudinal profiles indicates that this aggradation occurred between 1992 and 2013. 

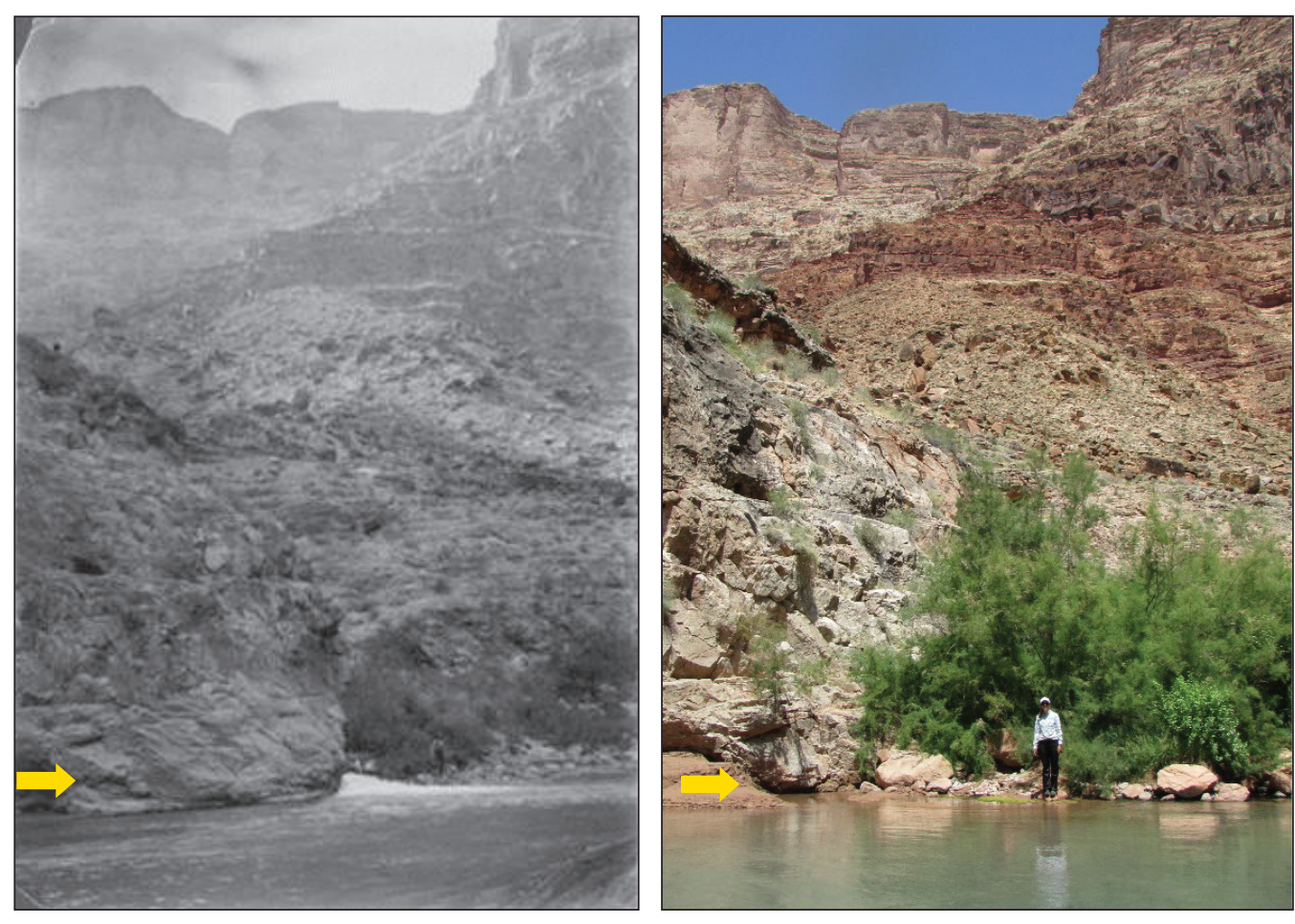

Figure 19. Repeated photographs from 1909 and 2013 of Blue Spring on the left bank of the Little Colorado River at river kilometer (Rkm) 20.8. The 1909 photograph was taken by Emery Kolb (left) and the 2013 photograph by Michael Pillow (right). Arrows mark the rock ledge visible in both photographs. The base-flow water surface was estimated to be $1 \pm 0.5$ meter $(\mathrm{m})$ higher in 2013 than in 1909; this estimation used a 1.7 -m-tall person for scale because this site was not measured in 2013. These comparisons showed that about $1 \mathrm{~m}$ of bed aggradation or travertine-dam growth occurred near Rkm 20.8 between 1909 and 2013.

\section{Mechanisms of Geomorphic Change}

The longitudinal profile of the lower Little Colorado River changed dramatically between 1909 and 2002 through the growth and collapse of travertine dams, tributary debris flows, and the likely mobilization of coarser gravel during larger Little Colorado River floods. Some of this change can be explained by the steady growth of travertine dams. If rates of travertinedam growth in the lower Little Colorado River were similar to those observed in other Arizona travertine streams, a 64-year period of undisturbed growth could yield a total growth of as much as $1.6 \mathrm{~m}$ at an individual dam. In April 2019, five travertine dams were observed between Rkms 0 and 1.2. The heights of these dams ranged from 0.4 to $2 \mathrm{~m}$, with a combined height estimated to be 4.2 to $5.7 \mathrm{~m}$. The difference in height from 1926 to 1992 at $\mathrm{Rkm} 1.2$ is $+3.2 \mathrm{~m}$. The mean growth rate per dam required for five dams to accumulate $3.2 \mathrm{~m}$ of height over 74 years is 0.01 meter per year $(\mathrm{m} / \mathrm{yr})$. At the growth rate of the Fossil Creek dams $(0.025 \mathrm{~m} / \mathrm{yr})$, the five dams in the lowest 1.2 $\mathrm{km}$ of the Little Colorado River could therefore have aggraded the observed $3.2 \mathrm{~m}$ in as little as 26 years.

Other instances of rapid aggradation in the reach cannot be explained by travertine-dam growth, however. These changes include the large increases in elevation between 1911 and 1926 at Rkms 9.45 and 11.15 and the large increase in elevation detected between 1926 and 1932 at Rkm 1.5. Tributary- and hillslope-generated debris flows are a potential mechanism of rapid channel aggradation in the lower Little Colorado River; their deposits commonly form the foundations of travertine dams. Persio (2004) examined 74 tributaries of the lower Little Colorado River and predicted occurrence rates of debris-flows of around 1 to 5 per century for each tributary. For example, the approximate $6 \mathrm{~m}$ of aggradation observed at Rkm 11.15 between 1911 and 1926 is too great to attribute to 15 years of travertine-dam growth. Big Canyon enters the Little Colorado River approximately $150 \mathrm{~m}$ downstream from the repeat-photograph site at $\mathrm{Rkm} 11.15$ and has one of the highest debris-flow-occurrence probabilities among all of the tributaries to the lower Little Colorado River (Persio, 2004), making it a likely source of a debris flow that may have caused the rapid aggradation that extended downstream past $\mathrm{Rkm}$ 9.45. The approximate $4 \mathrm{~m}$ of aggradation between 1926 and 1932 at the location of the 1932 photograph at Rkm 1.5 also cannot be fully explained by travertine-dam growth and must have partially involved the deposition of the boulders, likely between 1926 and 1932, in this photograph. Tributary debris flows have thus likely contributed to aggradation in the study area between 1911 and 2013, and debris flows are a likely mechanism for at least part of the observed rapid aggradation at Rkms $1.5,9.45$, and 11.15 that cannot be explained by travertine-dam growth alone.

Incision in the study area appears to occur by the collapse of travertine dams and reworking of the coarser gravel in debris-flow deposits during larger floods. The collapse of a single travertine dam occurs quickly, and the failure may propagate upstream. Travertine dams commonly form in complexes with multiple individual dams. As a single dam fails, the water-elevation drop in the upstream pool may destabilize the next dam upstream by increasing the difference in hydrostatic pressure between the upstream and downstream faces 
of that travertine dam and lead to the upstream propagation of multiple dam failures.

The longitudinal profiles and repeat photographs show evidence of one major dam failure between 1926 and 1951, although others likely occurred. The dam complex near Rkm 12 was present in 1911 and 1926, but then collapsed sometime between 1926 and 1951. This dam survived the $3,400-\mathrm{m}^{3} / \mathrm{s}$ flood in September 1923 and the 2,300- $\mathrm{m}^{3} / \mathrm{s}$ flood in December 1923, but collapsed sometime thereafter during a period when floods did not exceed $1,430 \mathrm{~m}^{3} / \mathrm{s}$. The longitudinal-profile data from 1909-1911 is incompletewith points only at Rkms 9.45, 11.15, 12.05, and 20.8-but the available data show either only aggradation or no change between 1911 and 1926, a period dominated by extremely large floods. This result indicates that the largest floods might, but do not necessarily, cause travertine-dam failure and channel incision.

\section{Ecological Implications of the Declines in Peak- Flow Magnitude and Associated Reduced Geomorphic Disturbance}

The decline in peak-flow magnitude, and the associated decline in geomorphic disturbance, likely has affected humpback chub populations within the lower Little Colorado River. Longer periods of base flow between large floods may increase travertine-dam growth and travertine cementation of the gravel bed. Although large parts of the longitudinal profile of the lower Little Colorado River may not change substantially, the absence of large floods will likely result in continued local aggradation through travertine-dam growth. Without a return to the larger floods that occurred before 1952, the large amounts of incision observed before the 1950s are unlikely. Currently, the only impediment to upstream chub movement is Chute falls, a feature that has existed only since sometime after 1926. Future debris flows are likely, as is the sustained growth of other travertine-dam complexes - both features that would not get reworked in the absence of large floods. Barriers to the upstream migration of humpback chub will thus likely only get larger, as observed between 1992 and 2013 in the case of Chute falls. The absence of large floods also affects the bed sediment and water depth within pools, and thus may also affect the spawning success of humpback chub. The infilling of pools with sediment and travertine cementation of gravel may disadvantage spawning humpback chub (Gorman and Stone, 1999), and both of these physicalchemical processes become more common in the absence of the larger floods that would scour pools and remobilize the gravel bed. Dean and Topping (2019) note that reoccurrence of the extremely large floods (that is, floods with peak flows greater that $400 \mathrm{~m}^{3} / \mathrm{s}$ ) that occurred before 1952 is extremely unlikely. It is also unlikely that the larger floods that were more common before the mid-1990s (that is, floods larger than $200 \mathrm{~m}^{3} / \mathrm{s}$ ) will reoccur on a regular basis. Thus, it is probable that the pools behind the travertine dams in the lower Little Colorado will only get shallower, and the gravel will only become more cemented in the future to the possible detriment of the humpback chub.

\section{Summary and Conclusions}

The Little Colorado River is a major tributary to the Colorado River with a confluence at the boundary between Marble and Grand Canyons within Grand Canyon National Park, Arizona. The bedrock gorge of the lower Little Colorado River is home to the largest known population of Gila cypha (humpback chub), an endangered fish endemic to the Colorado River Basin. Channel conditions might affect the spawning success of the humpback chub. Perennial base flow in the lower Little Colorado River deposits travertine, which forms dams and cascades. Geomorphic change in the lower Little Colorado River is controlled by the growth and collapse of travertine dams, debris flows from tributaries, and reworking of dams and debris fans by Little Colorado River floods.

A study was conducted by the U.S. Geological Survey, in cooperation with the Glen Canyon Dam Adaptive Management Program and the U.S. Fish and Wildlife Service, to document historical floods and geomorphic change in the lower Little Colorado River. For this study, we used historical and gaging records and hydraulic modeling of surveyed high-water marks from historical Little Colorado River floods to construct a peak-flow history of the lower Little Colorado River. We analyzed base-flow longitudinal profiles and historical photographs to determine changes in the longitudinal profile of the lower Little Colorado River from 1909 to 2019. The base-flow longitudinal profile of the lower Little Colorado River has changed dramatically since the early 1900s, with most of this change occurring during an era of larger floods that ended in the early 1950s. As observed in reaches of the Little Colorado River far upstream from the study area, the peak flow has declined substantially in the lower Little Colorado River. This peak-flow decline likely began after 1888 from $5,000 \mathrm{~m}^{3} / \mathrm{s}$ during the 1888 super-flood to $3,400 \mathrm{~m}^{3} / \mathrm{s}$ in 1923 and $705 \mathrm{~m}^{3} / \mathrm{s}$ in 1952 . Floods larger than $400 \mathrm{~m}^{3} / \mathrm{s}$ became rare after 1952, and floods larger than $200 \mathrm{~m}^{3} / \mathrm{s}$ have been extremely rare since the early 1990s. Before this period of post-1950 hydrologic quiescence, large episodes of both aggradation and incision occurred in the lower $22 \mathrm{~km}$ of the Little Colorado River. Since the early 1950s, however, the longitudinal profile has only remained stable or aggraded, with substantial post-1952 aggradation near Rkms 1, 1.5, 14, and 21. Unless large floods recur, it is likely that the habitat of humpback chub will continue to degrade, because travertine dams will continue to grow until they collapse because of instability (for example, Chute falls), debris-flow gravel will not get reworked, pools will not be deeply scoured, and the clean gravels preferred by spawning fish will likely become more cemented by travertine. 


\section{References Cited}

Adams, D.K., and Comrie, A.C., 1997, The North American monsoon: Bulletin of the American Meteorological Society, v. 78 , n. 10 , p. $2197-2213$.

Bell, H.S., 1937, A report on the history of the central area of the Little Colorado River Basin and its relation to flood and erosional conditions: Pasadena, Calif., California Institute of Technology, Soil Conservation Service Report, 92 p. plus plates.

Bills, D.J., Flynn, M.E., and Monroe, S.A., 2007, Hydrogeology of the Coconino Plateau and adjacent areas, Coconino and Yavapai Counties, Arizona (ver. 1.1, March 2016): U.S. Geological Survey Scientific Investigations Report 20055222, 101 p., 4 plates, https://doi.org/10.3133/sir20055222.

Birdseye, C.H., 1928, Topographic instructions of the United States Geological Survey: U.S. Geological Survey Bulletin $788,432 \mathrm{p}$.

Block, D., 2014, Historical channel-planform change of the Little Colorado River near Winslow, Arizona: U.S. Geological Scientific Investigations Report 2014-5112, 24 p., https://doi.org/10.3133/sir20145112.

Chow, V.T., 1959, Open channel hydraulics: New York, McGraw-Hill, 680 p.

Coggins, L.G., Jr., Pine, W.E., III, Walters, C.J., Van Haverbeke, D.R., Ward, D.L., and Johnstone, L., 2006, Abundance and status of the Little Colorado River population of humpback chub: North American Journal of Fisheries Management, v. 26, n. 1, p. $233-245$.

Cole, G.A., 1975, Calcite saturation in Arizona waters: Verhandlungen Internationale Vereinigung für Theoretische und Angewandte Limnologie 19, p. 1675-1685.

Collins, B.D., Brown, K.M., and Fairley, H.C., 2008, Evaluation of terrestrial LIDAR for monitoring geomorphic change at archeological sites in Grand Canyon National Park, Arizona: U.S. Geological Survey Open-File Report 2008-1384, $60 \mathrm{p}$.

Crossey, L.J., Karlstrom, K.E., Springer, A.E., Newall, D., Hilton, D.R., and Fischer, T., 2009, Degassing of mantlederived $\mathrm{CO}_{2}$ and $\mathrm{He}$ from springs in the southern Colorado Plateau region-Neotectonic connections and implications for groundwater systems: Geological Society of America Bulletin, v. 121, n. 7-8, p. 1034-1105, https://doi. org/10.1130/B26394.1.

Dean, D.J., and Topping, D.J., 2019, Geomorphic change and biogeomorphic feedbacks in a dryland river-The Little Colorado River, Arizona, USA: Geological Society of America Bulletin, v. 131, n. 11-12, p. 1920-1942.
Douglas, M.E., and Marsh, P.C., 1996, Population estimates/ population movements of Gila cypha, an endangered cyprinid fish in the Grand Canyon Region of Arizona: Copeia, p. 15-28.

Draut, A.E., Rubin, D.M., Dierker, J.L., Fairley, H.C., Griffiths, R.E., Hazel, J.E., Hunter, R.E., Kohl, K., Leap, L.M., Nials, F.L., and Topping, D.J., 2005, Sedimentology and stratigraphy of the Palisades, Lower Comanche, and Arroyo Grande areas of the Colorado River corridor, Grand Canyon, Arizona: U.S. Geological Survey Scientific Investigations Report 2005-5072, 68 p.

Fuller, B.M., Sklar, L.S., Compson, Z.G., Adams, K.J., Marks, J.C., and Wilcox, A.C., 2011, Ecogeomorphic feedbacks in regrowth of travertine step-pool morphology after dam decommissioning, Fossil Creek, Arizona: Geomorphology, v. 126, p. 314-332, https://doi.org/10.1016/j.geomorph. 2010.05.010.

Giegengack, R., Ralph, E.K., and Gaines, A.M., 1979, Havasu Canyon-A natural geochemical laboratory, in Linn, R.M., ed., Proceedings of the First Conference on Scientific Research in the National Parks, v. II: New Orleans, Louisiana, National Park Service, p. 719-726.

Gorman, O.T., and Stone, D.M., 1999, Ecology of spawning humpback chub, Gila cypha, in the Little Colorado River, near Grand Canyon, Arizona: Environmental Biology of Fishes, v. 55, p. 115-133.

Hansen, E.M., Schwarz, F.K., and Riedel, J.T., 1981, Meteorology of important rainstorms in the Colorado River and Great Basin drainages: National Oceanic and Atmospheric Administration Hydrometeorological Report no. $50,167 \mathrm{p}$.

Hereford, R., 1984, Climate and ephemeral-stream processes-Twentieth-century geomorphology and alluvial stratigraphy of the Little Colorado River, Arizona: Geological Society of America Bulletin, v. 95, p. 654-668.

Howard, A., and Dolan, R., 1981, Geomorphology of the Colorado River in Grand Canyon: Journal of Geology, v. 89, p. 269-297.

Johnson, P.W., and Sanderson, R.B., 1968, Spring flow into the Colorado River Lees Ferry to Lake Mead, Arizona: Arizona State Land Department Water-Resources Report no. $34,26 \mathrm{p}$.

Koenig, T.A., Bruce, J.L., O’Connor, J., McGee, B.D., Holmes, R.R., Jr., Hollins, R., Forbes, B.T., Kohn, M.S., Schellekens, M., Martin, Z.W., and Peppler, M.C., 2016, Identifying and preserving high-water mark data: U.S. Geological Survey Techniques and Methods, book 3, chap. A24, 47 p., http://doi.org/10.3133/tm3A24. 
Lighthill, M.J., and Whitham, G.B., 1955, On kinematic waves; I. Flood movement in long rivers: Proceedings of the Royal Society of London, series A, Mathematical, Physical and Engineering Sciences, v. 229, no. 1178, p. 281-316.

Magirl, C.S., Breedlove, M.J., Webb, R.H., and Griffiths, P.G., 2008, Modeling water-surface elevations and virtual shorelines for the Colorado River in Grand Canyon, Arizona: U.S. Geological Survey Scientific Investigations Report 2008-5075, 32 p.

Magirl, C.S., Webb, R.H., and Griffiths, P.G., 2005, Changes in the water surface profile of the Colorado River in Grand Canyon, Arizona, between 1923 and 2000: Water Resources Research, v. 41, W05021, https://doi.org/10.1029/ 2003WR002519.

McDonald, R.R., Nelson, J.M., and Bennett, J.P., 2005, Multidimensional surface-water modeling system user's guide: U.S. Geological Survey Techniques and Methods, book 6, chap. B2, 136 p.

Montgomery, D.R., and Buffington, J.M., 1997, Channelreach morphology in mountain drainage basins: Geological Society of America Bulletin, v. 109, no. 5, p. 596-611.

Nelson, J.M., 2016, FaSTMECH Solver Manual: International River Interface Cooperative, accessed March 7, 2019, at https://i-ric.org/en/download/FaSTMECH-solver-manual.

Nelson, J.M., Shimizu, Y., Takebayashi, H., and McDonald, R.R., 2010, The International River Interface Coopoerative-Public Domain Software for River Modeling: Proceedings of the 4th Federal Interagency Hydrologic Modeling Conference and of the 9th Federal Interagency Sedimentation Conference, $9 \mathrm{p}$.

Northern Arizona University, n.d., Cline Library digital collections: Northern Arizona University online database, accessed March 7, 2019, at https://cdm16748.contentdm. oclc.org/digital.

Persio, A.F., 2004, Assessment of changes in the water-surface profile of the lower canyon of the Little Colorado River, Arizona: Tucson, University of Arizona, M.S. thesis, 65 p.

Robinson, A.T., and Clarkson, R.W., 1992, Annual spring monitoring of humpback chub, Gila cypha, populations in the Little Colorado River, Grand Canyon, Arizona, 19871992: Phoenix, Arizona Game and Fish Department report prepared for U.S. Fish and Wildlife Service, Endangered Species Office, Albuquerque, N. Mex., $30 \mathrm{p}$.

Robinson, A.T., Kubly, D.M., Clarkson, R.W., and Creef, E.D., 1996, Factors limiting the distributions of native fishes in the Little Colorado River, Grand Canyon, Arizona: Southwestern Naturalist, v. 41, p. 378-389.
Sabol, T.A., Griffiths, R.E., Topping, D.J., Mueller, E.R., Tusso, R.B., and Hazel, J.E., Jr., 2021, Strandlines from large floods on the Colorado River in Grand Canyon National Park, Arizona: U.S. Geological Survey Scientific Investigations Report 2021-5048, 41 p., https://doi.org/ 10.3133/sir20215048.

Schmidt, J.C., Topping, D.J., Grams, P.E., and Hazel, J.E., 2004, System-wide changes in the distribution of fine sediment in the Colorado River corridor between Glen Canyon Dam and Bright Angel Creek, Arizona: Final report submitted to the U.S. Geological Survey Grand Canyon Monitoring and Research Center, Flagstaff, Arizona., 107 p., accessed March 15, 2021, at https://www.usbr.gov/ uc/progact/amp/amwg/2005-03-02-amwg-meeting/ Attach_05a.pdf.

Simões, F.J.M., 2009, SToRM-A numerical model for environmental surface flows: 33rd Congress of the International Association for Hydraulic Research, Vancouver, Canada, August 2009.

Stone, D.M., Young, K.L., Mattes, W.P., and Cantrell, M.A., 2018, Abiotic controls of invasive nonnative fishes in the Little Colorado River, Arizona: The American Midland Naturalist, v. 180, no. 1, p. 119-142.

Topping, D.J., Schmidt, J.C., and Vierra, L.E., 2003, Computation and analysis of the instantaneous-discharge record for the Colorado River at Lees Ferry, Arizona: May 8, 1921, through September 30, 2000: U.S. Geological Survey Professional Paper 1677, 118 p.

Unema, J.A., Topping, D.J., Caster, J.J., and Kohl, K.A., 2021, Topographic data, historical peak-stage data, and 2D flow models for the lowermost Little Colorado River, Arizona, USA, 2017: U.S. Geological Survey data release, https://doi.org/10.5066/P9VGWRV1.

U.S. Geological Survey, 1924, Plan and profile of Colorado River from Lees Ferry, Ariz., to Black Canyon, Ariz.-Nev. and Virgin River, Nev.: U.S. Geological Survey, 21 sheets.

U.S. Geological Survey, 1927, Plan and profile of Little Colorado River from mouth to Tolchico Dam Site, Arizona: U.S. Geological Survey, 5 sheets.

U.S. Geological Survey, 1952, Lower Little Colorado RiverBlue Springs Trip: Appendix to Arizona Council Minutes, no. 7-52.

U.S. Geological Survey, 2018, Stanton Repeat Photography Archive: U.S. Geological Survey, accessed March 10, 2019, at https://archive.usgs.gov/archive/sites/wwwpaztcn. wr.usgs.gov/fscc/stanton-repeat-photography/index.html. 
U.S. Geological Survey, 2019, USGS water data for the Nation: U.S. Geological Survey National Water Information System database, accessed March 10, 2019, at http://doi.org/ 10.5066/F7P55KJN.

U.S. Geological Survey, n.d., EarthExplorer: U.S. Geological Survey database, accessed March 6, 2019, at https://earthexplorer.usgs.gov.

Webb, R.H., 1987, Occurrence and geomorphic effects of streamflow and debris flow floods in southern Utah and northern Arizona, in Mayer, L., and Nash, D.B., eds., Catastrophic flooding: Boston, Allen and Unwin, p. 247-265.
Webb, R.H., 2010, Repeat photography-Methods and applications in the natural sciences: Washington, D.C., Island Press, 392 p.

Wiele, S.M., and Griffin, E.R., 1997, Modifications to a one-dimensional model of unsteady flow in the Colorado River through the Grand Canyon, Arizona: U.S. Geological Survey Water-Resources Investigations Report 97-4046, $17 \mathrm{p}$.

Wiele, S.M., and Smith, J.D., 1996, A reach-averaged model of diurnal discharge wave propagation down the Colorado River through the Grand Canyon: Water Resources Research, v. 32, no. 5, p. 1375-1386. 



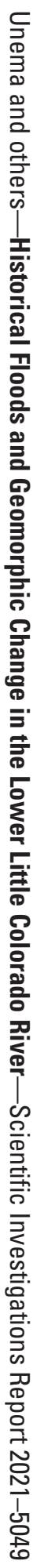

